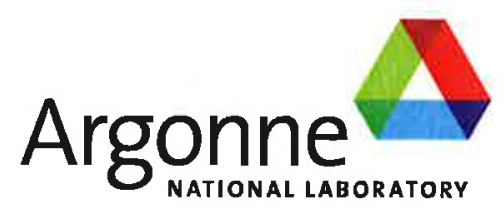

\title{
Uptakes of Cs and Sr on San Joaquin Soil Measured Following ASTM Method C1733
}

Chemical Sciences and Engineering Division 
About Argonne National Laboratory

Argonne is a U.S. Department of Energy laboratory managed by UChicago Argonne, LLC

under contract DE-AC02-06CH11357. The Laboratory's main facility is outside Chicago,

at 9700 South Cass Avenue, Argonne, Illinois 60439. For information about Argonne

and its pioneering science and technology programs, see www.anl.gov.

Availability of This Report

This report is available, at no cost, at http://www.osti.gov/bridge. It is also available

on paper to the U.S. Department of Energy and its contractors, for a processing fee, from:

U.S. Department of Energy

Office of Scientific and Technical Information

P.O. Box 62

Oak Ridge, TN 37831-0062

phone (865) 576-8401

fax (865) 576-5728

reports@adonis.osti.gov

This report was prepared as an account of work sponsored by an agency of the United States Government, Neither the United States Government nor any agency thereof, nor UChicago Argonne, LLC, nor any of their employees or officers, makes any warranty, express or implied, or assumes any legal liability or responsibility for the accuracy, completeness, or usefulness of any information, apparatus, product, or process disclosed, or represents that its use would not infringe privately owned rights. Reference herein to any specific commercial product, process, or service by trade name, trademark, manufacturer, or otherwise, does not necessarily constitute or imply its endorsement, recommendation, or favoring by the United States Government or any agency thereof. The views and opinions of document authors expressed herein do not necessarily state or refiect those of the United States Government or any agency thereof, Argonne National Laboratory, or UChicago Argonne, LLC. 


\section{Uptakes of Cs and Sr on San Joaquin Soil Measured Following ASTM Method C1733}

by

W.L. Ebert ${ }^{1}$ and E.T. Petri ${ }^{2}$

${ }^{1}$ Chemical Sciences and Engineering Division, Argonne National Laboratory

${ }^{2}$ Science Undergraduate Laboratory Internship Participant, University of Texas at Austin

March 2012 


\section{ACKNOWLEDGMENTS}

Emily Petri gratefully acknowledges support provided through the Student Research Participation Program of the Argonne National Laboratory Department of Educational Programs and the University of Texas at Austin. The authors thank Dr. Jeffery Fortner, Dr. Terry Cruse, Dr. Luis Ortega, and Ms. Yifen Tsai of the Chemical Sciences and Engineering Division for performing SEM, XRD, BET, and ICP-MS

analyses. Work was supported by the U.S. Department of Energy, Office of Nuclear Engineering, Science and Technology under contract W-31-109-Eng-38. 


\section{ACRONYMS}

$\begin{array}{ll}\text { ANL } & \text { Argonne National Laboratory } \\ \text { ASTM } & \text { American Society for Testing and Materials (ASTM-International) } \\ \text { DOE } & \text { U.S. Department of Energy } \\ \text { ICP-MS } & \text { Inductively coupled plasma-mass spectrometry } \\ \text { ILS } & \text { Inter-laboratory study } \\ K_{\mathrm{d}} & \text { Distribution coefficient } \\ \text { NIST } & \text { National Institute of Standards and Technology } \\ \text { SEM } & \text { Scanning electron microscope (or microscopy) } \\ \text { SRM } & \text { Standard reference material } \\ \text { XRD } & \text { X-ray diffraction }\end{array}$




\section{CONTENTS}

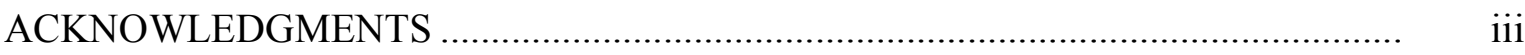

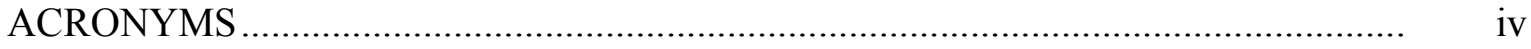

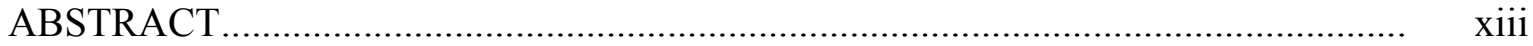

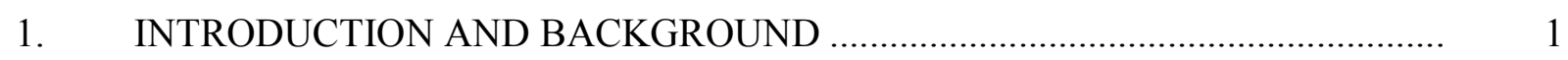

1.1. $\quad$ Measuring $K_{\mathrm{d}}$ with Laboratory Tests ........................................................... 2

2.2. ASTM C1733 Batch Test Method …............................................................. 3

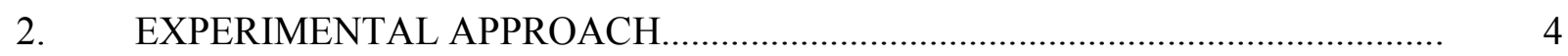

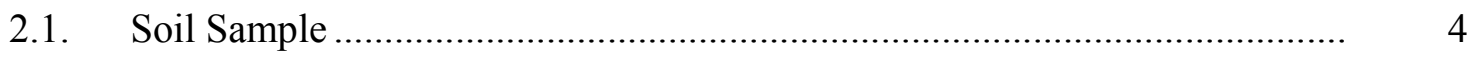

2.2. Solution Preparation........................................................................... 4

2.3. Vessel Preparation ........................................................................... 5

2.4. Test Method …................................................................................. 6

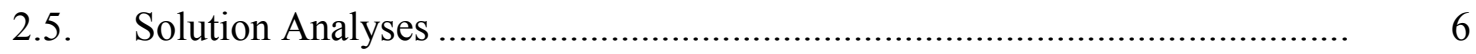

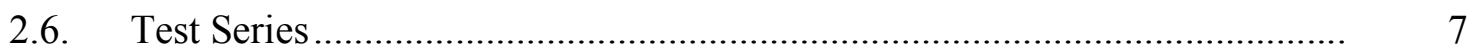

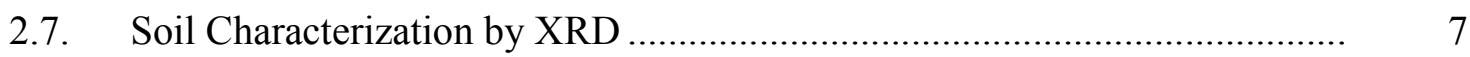

2.8. Soil Characterization by SEM …............................................................... $\quad 10$

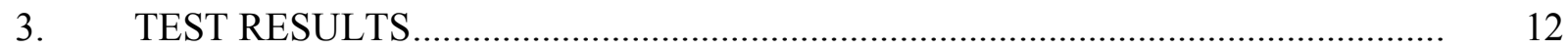

3.1. Soil Blank Tests .............................................................................. 12

3.2. Leachant Blank Tests ........................................................................... 12

3.3. Repeatability Tests...................................................................... 14

3.4. Effects of Scale Tests............................................................................ 21

3.5. Effects of Duration Tests ........................................................................... 23

3.6. Effects of $\mathrm{pH}$ Tests......................................................................... $\quad 30$

3.7. Effects of Concentration Tests............................................................ 35

3.8. Confirmation Tests.................................................................................... 48

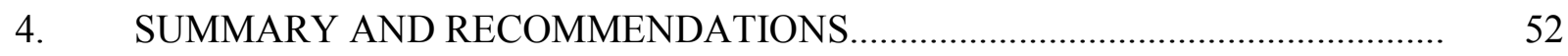

4.1. Testing Results............................................................................... 52

4.2. Recommended Conditions for an ASTM C1733 Reference Test................. 53

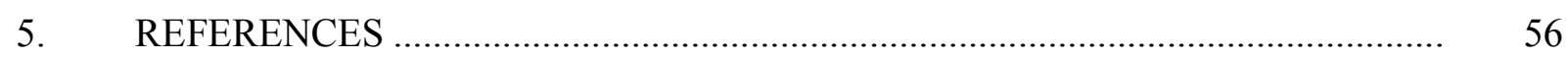

APPENDIX A Chemical Composition of SRM 2709a ......................................... 57

APPENDIX B Calculations ................................................................................. 59

APPENDIX C Propagation of Errors ................................................................ 65 


\section{LIST OF FIGURES}

Figure 1. XRD results of the San Joaquin soil sample from Jar 1 showing major peaks.

Figure 2. SEM photomicrographs of San Joaquin soil from Jar 1 at (a) low, (b) moderate, and (c) high magnification.

Figure 3. Results of replicate tests with Cs solution A: (a) masses of Cs in leachant, test solution, and taken up by soil, and (b) Cs concentrations in solution and on soil and $K_{\mathrm{d}}$ values.

Figure 4. Results of replicate tests with Sr solution A: (a) masses of Cs in leachant, test solution, and taken up by soil, and (b) Sr concentrations in solution and on soil and $K_{\mathrm{d}}$ values.

Figure 5. Results of tests with different amounts of soil and solution: (a) mass of Cs in leachant and in test solution or on soil vs. mass soil, (b) concentrations of Cs on soil and in solution, and $K_{\mathrm{d}}$ value, vs. mass soil.

Figure 6. Results of tests with different amounts of soil and solution: comparison of concentrations of Cs on soil and in solution, and $K_{\mathrm{d}}$ values for different masses of soil.

Figure 7. Results of tests conducted for different duration: (a) concentrations of Cs on soil and in solution, and $K_{\mathrm{d}}$ values vs. test duration and (b) expanded view of Cs on soil and $K_{\mathrm{d}}$ values.

Figure 8. Results of tests conducted for different duration: (a) concentrations of Sr on soil and in solution, and $K_{\mathrm{d}}$ values vs. test duration and (b) expanded view of Sr on soil and $K_{\mathrm{d}}$ values.

Figure 9. Results of tests conducted with different imposed $\mathrm{pH}$ values: (a) Cs masses in leachant, in test solution, and on soil vs. initial $\mathrm{pH}$ and (b) Sr masses in leachant, in test solution, and on soil vs. initial $\mathrm{pH}$.

Figure 10. Results of tests conducted with different imposed $\mathrm{pH}$ values: (a) concentrations of Cs on the soil and in solution, and $K_{\mathrm{d}}$ values, and (b) concentrations of $\mathrm{Sr}$ on the soil and in solution, and $K_{\mathrm{d}}$ values.

Figure 11. Correlation between Cs uptake onto soil and (a) Cs concentration in leachant prior to equilibration, and linear isotherm models with Cs concentration in solution after equilibration at (b) low and (c) high concentrations....

Figure 12. Correlation between $\mathrm{Sr}$ uptake onto soil and (a) $\mathrm{Sr}$ concentration in leachant prior to equilibration, and linear isotherm models with Sr concentration in solution after equilibration at (b) low and (c) high concentrations.

Figure 13. Evaluation of concentration effect using Freundlich isotherm models for (a) Cs and (b) $\mathrm{Sr}$.

Figure 14. Evaluation of concentration effect using Langmuir isotherm models for (a) Cs and (b) $\mathrm{Sr}$.

Figure 15. Comparison of confirmation tests result with measured composition dependence of $K_{\mathrm{d}}(\mathrm{Cs})$.

Figure 16. Results of effect of scale tests conducted with Leachant H. 


\section{LIST OF TABLES}

Table 1. Summary of peaks in XRD spectrum of NIST SRM 2709a …......................................... 9

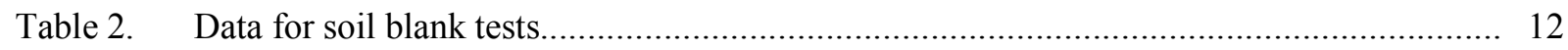

Table 3. Data and results for leachant blank tests............................................................... 13

Table 4. Combination of leachant blank test solutions for analysis............................................ 14

Table 5. Results for leachant blank tests. ............................................................................. 15

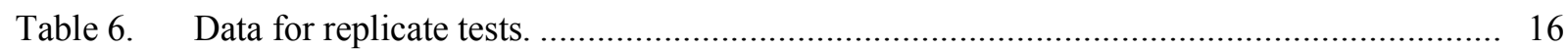

Table 7. Combination of replicate test solutions for analysis ........................................................ 17

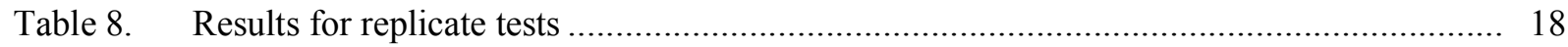

Table 9. Data for tests conducted with different amounts of soil and solution............................... 21

Table 10. Results for tests conducted with different amounts of soil and solution............................... 21

Table 11. Data for tests conducted for different durations. ........................................................... 24

Table 12. Combination of test solutions for tests conducted for different durations. ......................... 25

Table 13. Results for tests conducted for different durations..................................................... 26

Table 14. Data for tests conducted with leachants adjusted to different $\mathrm{pH}$ values.......................... 30

Table 15. Combination of solutions for tests conducted with leachants adjusted to different $\mathrm{pH}$

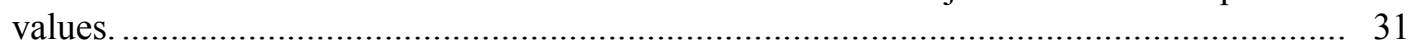

Table 16. Solution results for tests conducted with leachants adjusted to different $\mathrm{pH}$ values ........... 32

Table 17. Data for tests run with various Cs solution and Sr solution concentrations ........................ 35

Table 18. Combination of test solutions for analysis ................................................................. 37

Table 19. Solution results for tests using leachants with different $\mathrm{Cs}$ or $\mathrm{Sr}$ concentrations................. 38

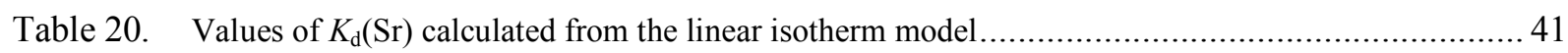

Table 21. Values of $K_{\mathrm{d}}(\mathrm{Cs})$ calculated from the Freundlich isotherm ................................................ 42

Table 22. Data used in Langmuir isotherm plots .......................................................................... 46

Table 23. Data for replicate tests with Leachant G..................................................................... 48

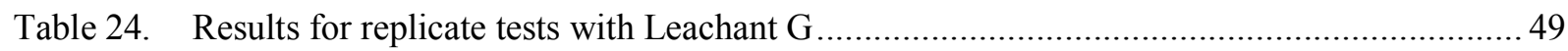

Table 25. Data for tests conducted with Leachant $\mathrm{H}$ and different amounts of soil and solution......... 50

Table 26. Results for tests conducted with Leachant $\mathrm{H}$ and different amounts of soil and solution 


\begin{abstract}
Series of tests were conducted following ASTM Standard Procedure C1733 to evaluate the repeatability of the test and the effects of several test parameters, including the solution-to-soil mass ratio, test duration, $\mathrm{pH}$, and the concentrations of contaminants in the solution. This standard procedure is recommended for measuring the distribution coefficient $\left(K_{\mathrm{d}}\right)$ of a contaminant in a specific soil/groundwater system. One objective of the current tests was to identify experimental conditions that can be used in future interlaboratory studies to determine the reproducibility of the test method. This includes the recommendation of a standard soil, the range of contaminant concentrations and solution matrix, and various test parameters. Quantifying the uncertainty in the distribution coefficient that can be attributed to the test procedure itself allows the differences in measured values to be associated with differences in the natural systems being studied.
\end{abstract}

Tests were conducted to measure the uptake of $\mathrm{Cs}$ and $\mathrm{Sr}$ dissolved as $\mathrm{CsCl}$ and $\mathrm{Sr}\left(\mathrm{NO}_{3}\right)_{2}$ in a dilute $\mathrm{NaHCO}_{3} / \mathrm{SiO}_{2}$ solution (representing contaminants in a silicate groundwater) by a NIST standard reference material of San Joaquin soil (SRM 2709a). Tests were run to measure the repeatability of the method and the sensitivity of the test response to the reaction time, the mass of soil used (at a constant soil-to-solution ratio), the solution $\mathrm{pH}$, and the contaminant concentration. All tests were conducted in screw-top Teflon vessels at $30{ }^{\circ} \mathrm{C}$ in an oven. All solutions were passed through a $0.45-\mu \mathrm{m}$ pore size cellulose acetate membrane filter and stabilized with nitric acid prior to analysis with inductivelycoupled plasma mass spectrometry (ICP-MS). Scoping tests with soil in demineralized water resulted in a solution $\mathrm{pH}$ of about 8.0 and the release of small amounts of $\mathrm{Sr}$ from the soil. Solutions were made with targeted concentrations of $1 \times 10^{-6} \underline{\mathrm{m}}, 1 \times 10^{-5} \mathrm{~m}$, $2.5 \times 10^{-5} \underline{\mathrm{m}}, 5 \times 10^{-5} \underline{\mathrm{m}}, 1 \times 10^{-4} \underline{\mathrm{m}}$, and $5 \times 10^{-4} \underline{\mathrm{m}}$ to measure the effects of the Cs and $\mathrm{Sr}$ concentrations on their uptake by the soil. The $\mathrm{pH}$ values of all solutions were adjusted to about $\mathrm{pH} 8.5$ so that the effects of $\mathrm{pH}$ and concentration could be measured separately. The $1 \times 10^{-4} \underline{\mathrm{m}}$ solutions were used to measure the repeatability of the test and the effects of duration, scale, and imposed $\mathrm{pH}$ on the test response.

The following reference conditions are recommended to measure the precision and bias of the test method and establishing a reference test response that can be used for direct comparisons of test execution and the effects of other test parameter and environmental variables:

Soil: NIST SRM 2709a San Joaquin soil without further treatment

Solution: $1.5 \times 10^{-4} \underline{\mathrm{m}} \mathrm{CsCl}(0.0253 \mathrm{~g} \mathrm{CsCl} / \mathrm{kg}$ solution $)$ in ASTM $\mathrm{C} 1220$ synthetic silicate groundwater

Solution pH: 8.5

Mass Ratio: $1.0 \mathrm{~g}$ soil in $25.0 \mathrm{~g}$ solution

Temperature: $30^{\circ} \mathrm{C}$

Duration: 2.0 days 


\section{INTRODUCTION AND BACKGROUND}

The ASTM standard procedure $\mathrm{C} 1733$ was recently issued as "a measurement technique for determining the degree of partitioning between liquid and solid, under a certain set of conditions, for the species of interest" (ASTM 2010). ASTM C1733 represents a significant revision of ASTM standard procedure D4319, which was withdrawn by ASTM in due, in part, to disbanding of the subcommittee D18.14 on Geotechnics of Waste Management that was responsible for maintaining and updating the standard. That method was revised and reissued by subcommittee C26.07 on Waste Materials (part of Nuclear Fuel Cycle committee $\mathrm{C} 26$ ), which made modifications to the test method and data analysis, provided a standard format for documenting the test results, and refined the recommended usage of the test results. The work described in this report was done to (1) evaluate the sensitivity of the ASTM C1733 test responses to several test parameters and provide measures of intra-laboratory precision and bias, and (2) identify a material and test conditions that can be used in a future study to measure inter-laboratory precision and bias.

The ASTM C1733 test procedure is a static method that can be used to measure the distribution coefficient $\left(K_{\mathrm{d}}\right)$ value of a particular system. (The terms distribution coefficient and partition coefficient are used interchangeably in the literature.) The distribution coefficient is commonly used to quantify the amount of a solute that has been removed from a solution due to interactions with a solid, and is defined as:

$K_{\mathrm{d}}=\frac{\text { mass of solute on the solid phase per unit mass of solid phase }}{\text { mass of solute in solution per unit volume of the liquid phase }}$.

This definition stems from the thermodynamic basis of distribution as it was developed to quantify equilibrium conditions for ion exchange reactions. The use of $K_{\mathrm{d}}$ has expanded to empirical use in contamination transport models, where the distribution coefficient is used to quantify the collective effects of several processes in addition to ion exchange, which may include sorption, absorption, precipitation, coprecipitation, size exclusion, complexation, and oxidation-reduction reactions. Most of these processes are expected to be sensitive to temperature, solution $\mathrm{pH}$ and $\mathrm{Eh}$, ionic strength, etc., and perhaps most importantly, to the solution concentration of the solute of interest. In such usage, the value of $K_{\mathrm{d}}$ represents the behavior of a particular solid and solution under a specific set of conditions, and may or may not be considered an equilibrium value.

While $K_{\mathrm{d}}$ values can be determined for any pure solid material, the focus of ASTM C1733 is measuring values for use in the modeling of contaminant transport through geological media. For application to soils, the texture, porosity, water and organic matter content of the soil, and the presence of microbes can also affect $K_{\mathrm{d}}$. In the procedure, it is stated that collected soils can be evaluated in the natural aggregated state or be disaggregated, and may be used in the natural state with retained pore water or may be dried. Note that $K_{\mathrm{d}}$ is calculated based on the dry mass of the soil, so a separate sample must be dried to determine the dry mass even if $K_{\mathrm{d}}$ is to be measured using a sample that is not dried. The state of the soil will affect the test result. The US Environmental Protection Agency has issued three reports that provide detailed discussion of the thermodynamic basis of $K_{\mathrm{d}}$ and the empirical use in contaminant transport models (EPA 1999a, EPA 1999b, EPA 2004). The reader is referred to these documents for more detailed and thorough descriptions of the processes that are summarized in this report. 


\subsection{Measuring $K_{\mathrm{d}}$ with Laboratory Tests}

The distribution coefficient $\left(\mathrm{K}_{\mathrm{d}}\right)$ is the ratio of the concentration of a substance in (on) a solid (in this case soil) per unit dry mass to the concentration in solution. The uncertainty in the measured value of $K_{\mathrm{d}}$ and the sensitivity to environmental conditions contribute inherently high uncertainties to source term models. The value of $K_{\mathrm{d}}$ can be measured in the laboratory using dynamic column tests or static batch tests. These methods can yield different values due to the effects of non-equilibrium, convection, and diffusion in the column method and failure to reach equilibrium in the batch method. In general, the batch method is used to provide values under hydrodynamically saturated and equilibrium conditions, whereas the column method is used to provide values for a more representative unsaturated soil condition. In column tests, the $50 \%$ breakthrough curves for the solvent (usually water) and solute are compared as

$$
\frac{V_{\text {solute }}}{V_{\text {water }}}=\frac{\theta}{1+\rho K_{\mathrm{d}} / \theta} \text {, }
$$

where $V_{\text {solute }}$ and $V_{\text {water }}$ are the volumes at $50 \%$ solute breakthrough and water breakthrough, respectively, $\rho$ is the density of the soil and $\theta$ its volumetric water content. The denominator in this equation is often referred to as the retardation factor $\mathrm{R}$

$$
\mathrm{R}=1+\rho K_{\mathrm{d}} / \theta \text {. }
$$

The retardation factor is commonly used in the advection-dispersion equations included in contaminant transport calculations and occurs in the denominator of a dispersion term. Higher values of $K_{\mathrm{d}}$ indicate stronger interactions between the contaminant and soil and slower transport. The effect of $K_{\mathrm{d}}$ on the amount of material released and transported increases with the reaction time. The distribution coefficient can be written as

$$
K_{\mathrm{d}}=\frac{C_{\text {sorbed }}\left(g_{\text {contaminant }} / g_{\text {soil }}\right)}{C_{\text {test solution }}\left(g_{\text {contaminan } \mathrm{t}} / m L_{\text {test solution }}\right)},
$$

where $C_{\text {sorbed }}$ is the concentration of the contaminant that has been taken up by the soil and $C_{\text {solution }}$ is the concentration of the contaminant remaining in solution. In the batch tests, soil and a solution containing a known amount of contaminant are shaken together and left to react for a period of time sufficient for the system to equilibrate. In this report, the initial solution is referred to as the leachant to distinguish it from the solution recovered at the end of the test, which is referred to as the test solution. The value of $K_{d}$ is determined from the initial contaminant concentration (mass) in the leachant and concentration (mass) of the contaminant in the test solution. Equation 4 can be rearranged to give Equation 5:

$$
K_{\mathrm{d}}=\frac{C_{\text {leachant }} \bullet V_{\text {leachant }}}{C_{\text {test solution }} \bullet M_{\text {soil }}}-\frac{V_{\text {test solution }}}{M_{\text {soil }}} .
$$

Since $K_{d}$ is the ratio of two measured concentrations ( $C_{\text {leachant }}$ and $\left.C_{\text {test solution }}\right)$, small errors in measurement can lead to a large error in the ratio. Values of $K_{d}$ can also be inferred from field tests and field modeling studies using inverse modeling methods. 


\section{$1.2 \quad$ ASTM C1733 Batch Test Method}

Due to the many process that affect the distribution coefficient, the use of generic $K_{\mathrm{d}}$ values for particular contaminants and soil types is strongly discouraged in the procedure, as inappropriate values can greatly impact contaminant migration and site-remediation analyses (e.g., Yu et al 2001). In current practice, bounding values of $K_{d}$ are often used to provide conservative estimates to evaluate remediation needs. Conservatively low values of $K_{d}$ are used when groundwater contamination is of concern and conservatively high values are used when soil contamination is of concern. Nevertheless, measurements made under site-specific conditions are considered to be essential for defensible assessments. The ASTM C1733 recommends careful collection of groundwater and soils, stabilization during transport to the laboratory and storage, and detailed characterization of the groundwater and soil mineralogy. While the test method itself is simple to perform, the sensitivity of test response to condition of the solid and the groundwater chemistry requires the utmost care during sample collection, handling, and storage for representative results.

Likewise, the usefulness of the measured values is greatly increased if dependencies of the $K_{\mathrm{d}}$ value on key environmental variables can be quantified, probably most importantly the contaminant concentration in the groundwater. For example, the method recommends that measurements be made for a range of contamination concentrations that can be used to develop an analytical relationship between the contaminant concentration and the $K_{\mathrm{d}}$ value. This is usually quantified in the form of an adsorption isotherm, although the contributions of other processes besides adsorption are taken into account in the (empirical) measured value. While the dependence on the contaminant concentration is probably the most important relationship for remediation analyses, additional relationships can be determined between $K_{\mathrm{d}}$ values and other environmental factors, such as $\mathrm{pH}, \mathrm{T}$, and $\mathrm{Eh}$ (groundwater redox), the presence of complexants and competing species, ionic strength, etc. Other than stressing the importance of simulating the natural conditions, ASTM C1733 does not address these other dependencies. Though it is not addressed in ASTM C1733, the reversibility of contaminant uptake can be measured following the same procedure to provide additional insight into the dominant process.

The ASTM C1733 method recommends that tests be conducted at reference $\mathrm{pH}$ and temperature values and at a reference water-to-soil mass ratio to facilitate comparisons of other contaminants and soils, but only provides the recommended water-to-soil mass ratio. Since $K_{\mathrm{d}}$ is usually considered to be an equilibrium value, the method calls for the use of scoping tests to determine the duration required to reach a constant solution concentration indicating the system has reached equilibrium (or steady state). Since this will vary with the system being evaluated, it is left to the user to determine the appropriate test duration. One objective of the research presented in this report is to provide a set of reference test conditions that can be included in ASTM C1733 for direct comparison of results obtained at different laboratories.

Because the purpose of this study was to evaluate repeatability of the test method and sensitivity to test parameters exclusive of the uncertainties inherent in collected soil and groundwater, a sample of San Joaquin soil was purchased from the National Institute for Standards and Technology (NIST) and used as the geologic medium. This is a dried soil that has been crushed, sized, and well mixed. The gross chemical composition has been certified as uniform in the 50-g subsamples provided as SRM 2709a (see NIST 2011 and Appendix A). An ASTM synthetic silicate groundwater spiked with small amounts of either $\mathrm{CsCl}$ or $\mathrm{Sr}\left(\mathrm{NO}_{3}\right)_{2}$ was used to represent contaminated groundwater. 


\section{EXPERIMENTAL APPROACH}

\subsection{Soil Sample}

San Joaquin Soil supplied by the National Institute of Standards and Technology was used as the solid: Standard Reference Material 2709a (NIST 2009). The gross composition of SRM 2709a has been standardized, with the concentrations of 19 constituent elements being certified, reference values for 15 elements, and information values provided for 10 constituents. (The elemental compositions provided with SRM 2709a are included in Appendix A.) The soil is provided as a finely divided powder that passes through a 200 mesh sieve ( $75 \mu \mathrm{m}$ openings). This material was selected, in part, based on its availability and the intent of using this SRM in a future inter-laboratory study to further evaluate the ASTM C1733 method. Although the mineralogy of the soil is not standardized, it is assumed that the consistency of the composition reflects consistency in the mineral constituents. Soil from two $50 \mathrm{~g}$ bottles of SRM 2709a was used in the study. These are referred to as Jar 1 and Jar 2. The source for each test is indicated in the prefix of the test number as SJ1 and SJ2 for soil taken from Jar 1 and Jar 2, respectively.

\subsection{Solution Preparation}

To mimic a generic groundwater, a silicate solution containing sodium bicarbonate and silicic acid was used to prepare all of the cesium and strontium solutions. The silicate solution was prepared following the method outlined by ASTM Standard Procedure C1220 in step 7.4. All of the solid reagents were dried at about $150{ }^{\circ} \mathrm{C}$ prior to use, and freshly demineralized water $(17.8 \mathrm{M} \Omega \mathrm{cm})$ was used. Four liters of the silicate solution was prepared in two 2-liter Nalgene bottles. In each bottle, $0.358 \mathrm{~g} \mathrm{SiO}_{2} \cdot 2 \mathrm{H}_{2} \mathrm{O}$ and $0.192 \mathrm{~g} \mathrm{NaHCO}_{3}$ were mixed with enough demineralized water to make $2 \mathrm{~kg}$ solution. Small amounts of dilute $\mathrm{HNO}_{3}$ and $\mathrm{NaOH}$ solutions were then added to adjust the solutions in the two bottles to $\mathrm{pH} 8.99$ and $\mathrm{pH} 8.98$, respectively. The solution $\mathrm{pH}$ was measured with a combination electrode that was calibrated with $\mathrm{pH} 3,7$, and 10 buffers before and after the solutions were analyzed.

An approximately $0.02 \mathrm{~m} \mathrm{CsCl}$ stock solution was prepared by adding $0.3351 \mathrm{~g} \mathrm{CsCl}$ to the silicate solution to make $100.02 \mathrm{~g}$ of solution. [Molality $(\underline{\mathrm{m}})$ is defined as moles solute per kg solution.] This solution was diluted to prepare two other solutions:

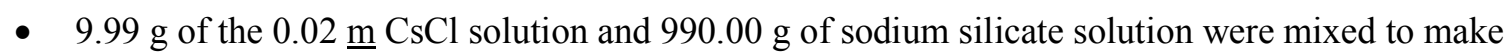
$999.99 \mathrm{~g}$ of the $1 \times 10^{-4} \mathrm{~m} \mathrm{CsCl}$ solution, which is referred to as Cs solution A.

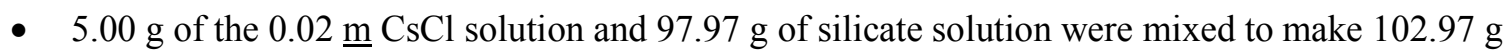
of a $5 \times 10^{-4} \underline{\mathrm{m}} \mathrm{CsCl}$ solution. This is referred to as Cs solution B.

Aliquots of solutions $\mathrm{A}$ and $\mathrm{B}$ were diluted to make other $\mathrm{CsCl}$ solutions for use in the series of tests to study the effects of the Cs concentration:

- $50.00 \mathrm{~g}$ of the $1 \times 10^{-4} \mathrm{~m}$ solution and $51.80 \mathrm{~g}$ of the sodium silicate solution were mixed to make $101.80 \mathrm{~g}$ of the $5 \times 10^{-5} \underline{\mathrm{m}} \mathrm{CsCl}$ solution. This is referred to as Cs solution $\mathrm{C}$.

- $10.02 \mathrm{~g}$ of the $1 \times 10^{-4} \mathrm{~m}$ solution and $90.11 \mathrm{~g}$ of the sodium silicate solution were mixed to make $100.13 \mathrm{~g}$ of the $1 \times 10^{-5} \underline{\mathrm{m}} \mathrm{CsCl}$ solution. This is referred to as Cs solution $\mathrm{D}$.

- $1.00 \mathrm{~g}$ of the $1 \times 10^{-4} \mathrm{~m}$ solution and $99.00 \mathrm{~g}$ of the sodium silicate solution were mixed to make $100.00 \mathrm{~g}$ of the $1 \times 10^{-6} \mathrm{~m} \mathrm{CsCl}$ solution. This is referred to as Cs solution $\mathrm{E}$.

- $5.01 \mathrm{~g}$ of the $5 \times 10^{-4} \underline{\mathrm{m}}$ solution and $94.97 \mathrm{~g}$ of the sodium silicate solution were mixed to make $100.01 \mathrm{~g}$ of the $2.5 \times 10^{-5} \mathrm{~m} \mathrm{CsCl}$ solution. This is referred to as Cs solution $\mathrm{F}$. 
The $\mathrm{CsCl}$ solutions $\mathrm{C}, \mathrm{D}, \mathrm{E}$, and $\mathrm{F}$ were then adjusted to $\mathrm{pH} 8.5$ by the addition of small amounts of $\mathrm{HNO}_{3}$ or $\mathrm{NaOH}$ to separate the effects of solution $\mathrm{pH}$ from Cs concentration. A portion of the A solution was also adjusted to $\mathrm{pH} 8.5$ by adding a small amount of $\mathrm{HNO}_{3}$; the $\mathrm{pH}$-adjusted solution is referred to as A2.

The strontium solutions were prepared following the same procedure. An approximately $0.02 \underline{\mathrm{m}} \operatorname{Sr}\left(\mathrm{NO}_{3}\right)_{2}$ solution was prepared by adding $0.4279 \mathrm{~g} \mathrm{Sr}\left(\mathrm{NO}_{3}\right)_{2}$ to the silicate solution to make $100.03 \mathrm{~g}$ final solution. This solution was diluted to prepare the other $\mathrm{Sr}$ solutions:

- $10.60 \mathrm{~g}$ of the $0.02 \underline{\mathrm{m}} \mathrm{Sr}\left(\mathrm{NO}_{3}\right)_{2}$ solution and $990.07 \mathrm{~g}$ of sodium silicate solution were mixed to make $1000.67 \mathrm{~g}$ of the $1 \times 10^{-4} \underline{\mathrm{m} \mathrm{Sr}}\left(\mathrm{NO}_{3}\right)_{2}$ solution, which is referred to as $\mathrm{Sr}$ solution A.

- $5.01 \mathrm{~g}$ of the $0.02 \mathrm{~m} \mathrm{Sr}\left(\mathrm{NO}_{3}\right)_{2}$ solution and $95.04 \mathrm{~g}$ of silicate solution were mixed to make $100.05 \mathrm{~g}$ of a $5 \times 10^{-4} \underline{\mathrm{m}} \mathrm{Sr}\left(\mathrm{NO}_{3}\right)_{2}$ solution. This is referred to as $\mathrm{Sr}$ solution B.

Aliquots of solutions $\mathrm{A}$ and $\mathrm{B}$ were diluted to make other $\operatorname{Sr}\left(\mathrm{NO}_{3}\right)_{2}$ solutions:

- $50.01 \mathrm{~g}$ of the $1 \times 10^{-4} \mathrm{~m}$ solution and $50.02 \mathrm{~g}$ of the sodium silicate solution were mixed to make $100.03 \mathrm{~g}$ of the $5 \times 10^{-5} \underline{\mathrm{m}} \mathrm{Sr}\left(\mathrm{NO}_{3}\right)_{2}$ solution. This is referred to as $\mathrm{Sr}$ solution $\mathrm{C}$.

- $\quad 10.05 \mathrm{~g}$ of the $1 \times 10^{-4} \mathrm{~m}$ solution and $89.95 \mathrm{~g}$ of the sodium silicate solution were mixed to make $100.00 \mathrm{~g}$ of the $1 \times 10^{-5} \underline{\mathrm{m}} \mathrm{Sr}\left(\mathrm{NO}_{3}\right)_{2}$ solution. This is referred to as $\mathrm{Sr}$ solution $\mathrm{D}$.

- $\quad 1.02 \mathrm{~g}$ of the $1 \times 10^{-4} \mathrm{~m}$ solution and $100.48 \mathrm{~g}$ of the sodium silicate solution were mixed to make $101.50 \mathrm{~g}$ of the $1 \times 10^{-6} \underline{\mathrm{m} \mathrm{Sr}}\left(\mathrm{NO}_{3}\right)_{2}$ solution. This is referred to as $\mathrm{Sr}$ solution $\mathrm{E}$.

- $\quad 5.00 \mathrm{~g}$ of the $5 \times 10^{-4} \mathrm{~m}$ solution and $95.02 \mathrm{~g}$ of the sodium silicate solution were mixed to make $100.02 \mathrm{~g}$ of the $2.5 \times 10^{-5} \underline{\mathrm{m}} \mathrm{Sr}\left(\mathrm{NO}_{3}\right)_{2}$ solution. This is referred to as $\mathrm{Sr}$ solution $\mathrm{F}$.

The $\mathrm{Sr}\left(\mathrm{NO}_{3}\right)_{2}$ solutions $\mathrm{C}, \mathrm{D}, \mathrm{E}$, and $\mathrm{F}$ were adjusted to $\mathrm{pH} 8.5$ by the addition of small amounts of $\mathrm{HNO}_{3}$ or $\mathrm{NaOH}$ to separate the effects of solution $\mathrm{pH}$ from $\mathrm{Sr}$ concentration. A portion of the A solution was also adjusted to $\mathrm{pH} 8.5$ by adding a small amount of $\mathrm{HNO}_{3}$; the $\mathrm{pH}$-adjusted solution is referred to as $\mathrm{A} 2$. The $\mathrm{Cs}$ and $\mathrm{Sr}$ concentrations in all of the final solutions were measured directly in the leachant blank series.

The densities of Cs solution A and Sr solution A were measured using a $100 \mathrm{~mL}$ volumetric flask as follows. The volume of the flask was measured first by filling to just below the line with demineralized water, equilibrating at $30.0^{\circ} \mathrm{C}$, and then adding enough water to raise the meniscus to line. The filled volumetric was weighed to determine the mass of water, and the volume calculated by using the known density of air-saturated water at $30.0{ }^{\circ} \mathrm{C}\left(0.99565 \mathrm{~g} / \mathrm{cm}^{3}\right)$. The masses of Cs solution A and $\mathrm{Sr}$ solution A required to fill the volumetric were then measured at ambient temperature and divided by the known volume of the flask to calculate the density. The density of Cs solution A was determined to be $0.9946 \mathrm{~g} / \mathrm{cm}^{3}$ and that of $\mathrm{Sr}$ solution A $0.9966 \mathrm{~g} / \mathrm{cm}^{3}$. These values were used as the densities of the other Cs and Sr solutions, as well.

\subsection{Vessel Preparation}

Thirty 45-mL Teflon screw top vessels were cleaned for use in these tests. The vessels had been used in previous tests and had been cleaned with dilute $\mathrm{NaOH}$ solutions when new and then with dilute nitric acid solutions and water after use in other tests. The vessels were cleaned prior to use in these tests as follows. The vessels were subjected to three washes with demineralized water and then filled with demineralized water and 5 drops (about $1 \mathrm{~mL}$ ) of concentrated nitric acid, capped, and shaken to help mix the acid and rinse the cap. The containers were then placed in a $70{ }^{\circ} \mathrm{C}$ oven overnight. The acid solution was 
discarded the following morning and the vessels and caps rinsed three times with demineralized water. The vessels were then filled with demineralized water, capped, and placed in a $70{ }^{\circ} \mathrm{C}$ oven overnight. The water was discarded the following morning and the vessels were dried in the oven then capped for storage. The Teflon containers were labeled 1-30.

\subsection{Test Method}

Simple batch experiments were performed to determine how much cesium and strontium was taken up by the soil. Tests were conducted by placing a weighed amount of SRM 2709a soil in a clean Teflon vessel and adding a known mass of solution. The vessels were tightly sealed with screw-top lids, shaken to suspend the soil in the solution, and then placed in a convection oven that was set to $30.0^{\circ} \mathrm{C}$ using a NIST-traceable thermometer. The test was considered to be initiated at the time it was placed in the oven, even though about 30 minutes were required to heat the vessel from ambient to $30.0{ }^{\circ} \mathrm{C}$. The vessels were shaken to suspend the solids at the beginning and end of the work day. The termination time was taken to be the time at which the solution was removed from the vessel, even though the vessel had been removed from the oven several minutes earlier. Vessels were shaken to suspend the solids when they were removed from the oven, then allowed to settle for several minutes before the vessels were opened. The leachates were decanted from the test vessel into a syringe fitted with a $0.45 \mu \mathrm{m}$ pore size polycarbonate syringe filter. A small amount of soil was entrained in the solution poured into the syringe. The solution was forced through the filter with a plunger and collected in a pre-weighed solution bottle. A small sample of each filtrate (about $1 \mathrm{~mL}$ ) was removed from the solution bottle with a pipette for $\mathrm{pH}$ analysis. The solution $\mathrm{pH}$ was measured at ambient temperature using a combination microelectrode that had been calibrated with three commercial buffer solutions $(\mathrm{pH} \mathrm{3,} \mathrm{pH} 7$, and $\mathrm{pH} 10)$ prior to the measurements. The remaining filtrate was acidified with about $0.05 \mathrm{~mL}$ concentrated nitric acid and stored several days prior to analysis with inductively coupled plasma-mass spectrometry (ICP-MS). Blank tests conducted without soil were treated the same as tests with soil, including the filtration step. Solutions from each test series, including blank tests, were analyzed as a set to eliminate day-to-day variance in the performance of the ICP-MS. Solutions from some tests with the $\mathrm{Cs}$ and $\mathrm{Sr}$ solutions of similar concentrations were combined for analyses to lower the analytical costs.

\subsection{Solution Analysis}

All solutions were analyzed for Cs and Sr using inductively coupled plasma-mass spectrometry (ICPMS). Some solutions were also analyzed for $\mathrm{Na}$ and $\mathrm{Si}$. To reduce analytical costs, the solutions from some tests conducted with the Cs leachant were mixed with the solution from a corresponding test conducted with the Sr leachant and analyzed as a single sample. Each solution was stabilized with concentrated $\mathrm{HNO}_{3}$ before mixing and the amounts of each solution were measured. Each leachant provides the same matrix (a dilute silicate solution near $\mathrm{pH}$ 8.7) and $\mathrm{Cs}$ and $\mathrm{Sr}$ do not have interferences in the ICP-MS analysis. Demineralized water was added to a few solutions (prior to acidification) to provide sufficient solution for analysis (at least $10 \mathrm{~mL}$ ).

The $\mathrm{pH}$ was measured for samples of most solutions using a combination electrode. The $\mathrm{pH}$ values of commercial buffer standards were measured to calibrate the meter response before and after the test samples were analyzed to account for drift. The initially-measured $\mathrm{pH}$ values of the buffers were recorded but the meter was not adjusted. Instead, the as-measured values of the unknown solutions were measured and recorded, and then the buffers were reanalyzed. A calibration curve was determined later using the two sets of measured buffer $\mathrm{pH}$ values (i.e., before and after measuring the test solutions) and 
this was used to calculate the $\mathrm{pH}$ values of the test solutions. This approach takes into account any drift in the $\mathrm{pH}$ meter that occurred during the measurements.

\subsection{Test Series}

Several series of tests were conducted to evaluate various aspects of the ASTM C1733 procedure. All tests were conducted at $30^{\circ} \mathrm{C}$. These are summarized below:

Soil Blank Tests-A series of tests was run with $12.5 \mathrm{~g}$ demineralized water and $0.5 \mathrm{~g}$ soil to measure the amounts of Cs and Sr released from the San Joaquin soil into solution during 1-, 3-, and 7-day test durations.

Leachant Blank Tests-A series of tests was run with $12.5 \mathrm{~g}$ of each leachant without soil for 1,2 and 7 days to evaluate the stabilities of the solutions and any interactions with the Teflon vessels. The measured concentrations were used as background values for other tests.

Repeatability Tests-Series of 5 replicate tests were conducted for 1- and 2-day durations with the $1 \times 10^{-4} \underline{\mathrm{m}}$ Cs A solution and for 1 day with the $1 \times 10^{-4} \underline{\mathrm{m}}$ Sr A solution, all with $1 \mathrm{~g}$ soil and $25 \mathrm{~g}$ solution.

Effects of Scale Tests-A series of tests was conducted using the $1 \times 10^{-4} \underline{\mathrm{m}}$ Cs A solution to study the effect of scale. Tests were conducted for 1 day durations with $0.2,0.5,1$, and $1.5 \mathrm{~g}$ soil and the appropriate amount of solution to attain a mass ratio of $25 \mathrm{~g}$ solution-to- $1 \mathrm{~g}$ solid. These tests address the homogeneity of the soil and test uncertainty associated with handling different amounts of solid and solution.

Effects of Duration Tests-A series of tests was conducted with the $1 \times 10^{-4} \underline{\mathrm{m}}$ Cs A solution and the $1 \times 10^{-4} \underline{\mathrm{m}} \mathrm{Sr}$ A solution for durations between 15 minutes and 7 days to track the approach to equilibrium (steady state). Tests were conducted at a mass ratio of $12.5 \mathrm{~g}$ solution and $0.5 \mathrm{~g}$ soil.

Effects of $\mathrm{pH}$ Tests-A series of tests was conducted with samples of the $1 \times 10^{-4} \underline{\mathrm{m}} \mathrm{Cs}$ A2 solution and the $1 \times 10^{-4} \underline{\mathrm{m}} \mathrm{Sr} \mathrm{A} 2$ solution that were adjusted to $\mathrm{pH}$ values of $6.5,7.0,8.0$, and 8.5. Tests were conducted for 1 and 2 days at a mass ratio of $12.5 \mathrm{~g}$ solution and $0.5 \mathrm{~g}$ soil.

Effects of Concentration Tests-Series of tests were conducted using six different Cs concentrations and six different $\mathrm{Sr}$ concentrations (i.e., the A2, B, C, D, E, and F solutions) for 1, 2, and 3 days at a mass ratio of $12.5 \mathrm{~g}$ solution and $0.5 \mathrm{~g}$ soil to quantify the effect of the solution concentration on $K_{\mathrm{d}}$ in the form of sorption isotherms.

\subsection{Soil Characterization by XRD}

Powder x-ray diffraction (XRD) was performed on a small sample of soil from Jar 1. Sections of the resulting spectrum are shown in Figure 1, and the measured values of two theta and intensity values for the major peaks are given in Table 1 with the calculated $d$-spacings, estimated background intensities, and calculated relative intensities. The $d$-spacings of the peaks were calculated using the Bragg diffraction equation (calculations are discussed in Appendix B) with an X-ray wavelength of $\lambda=0.15406 \mathrm{~nm}$ : 


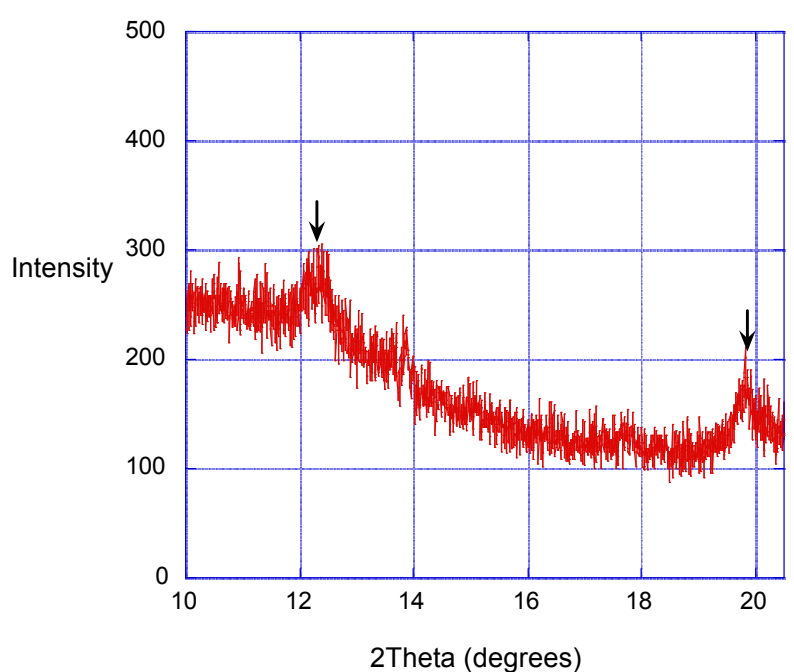

(a)

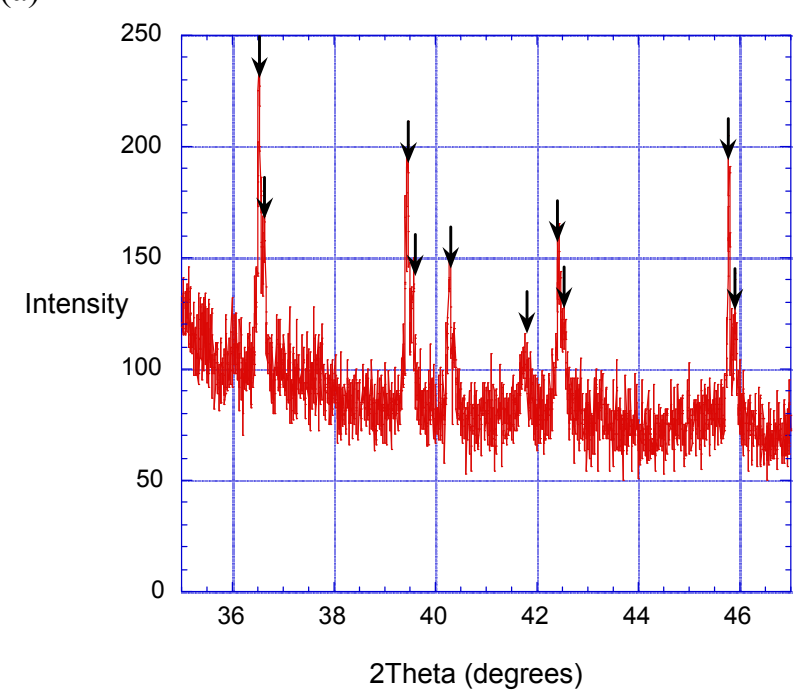

(d)

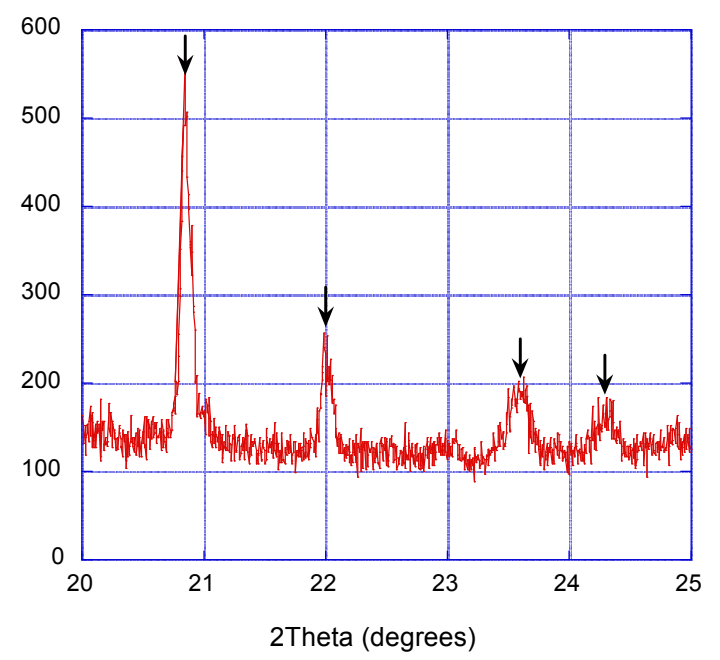

(b)

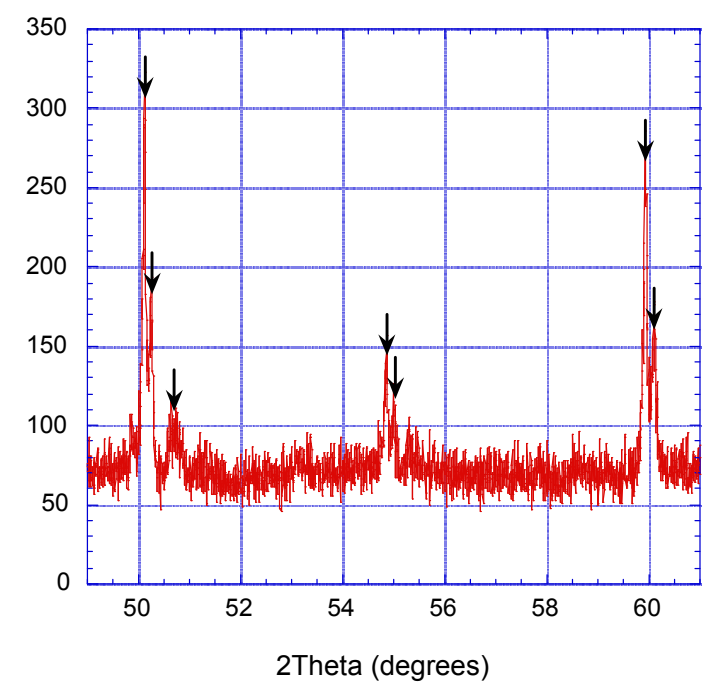

(e)

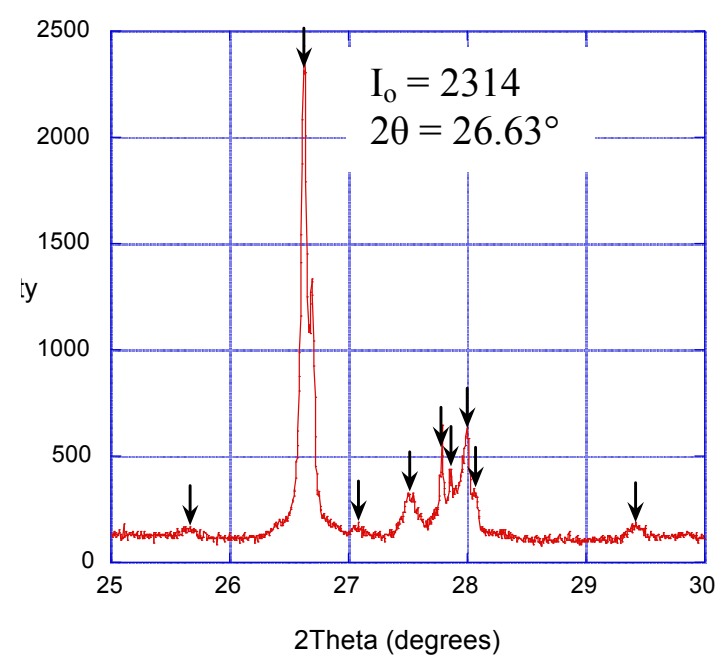

(c)

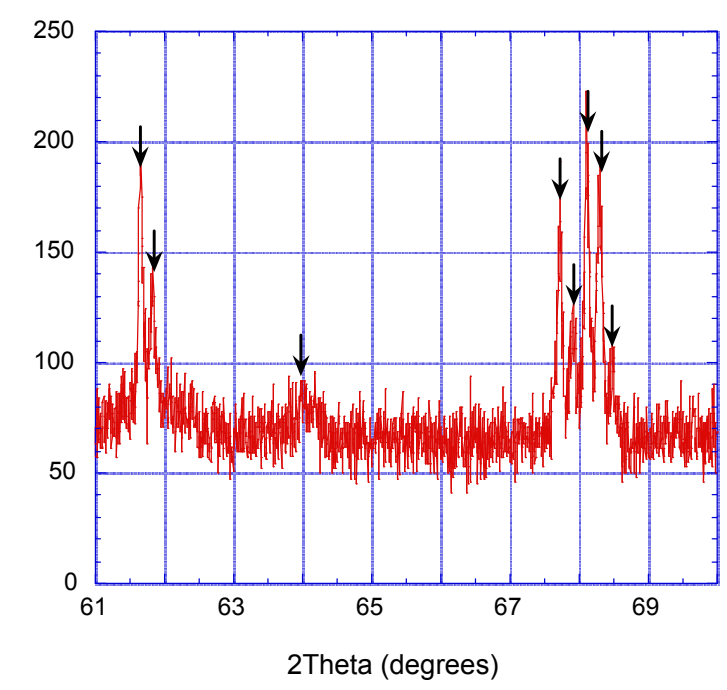

(f)

Figure 1. XRD results of the San Joaquin soil sample from Jar 1 showing major peaks. The arrows locate the peaks that are included in Table 1. 
Table 1. Summary of peaks in XRD spectrum of NIST SRM 2709a

\begin{tabular}{|c|c|c|c|c|}
\hline 2 Theta & d-spacing, $\AA$ & I, relative & I, background & I/Io \\
\hline 12.317 & 7.180 & 302 & 229 & 3.2 \\
\hline 19.819 & 4.476 & 211 & 124 & 3.8 \\
\hline 20.842 & 4.259 & 567 & 131 & 18.8 \\
\hline 21.983 & 4.040 & 257 & 122 & 5.8 \\
\hline 23.580 & 3.770 & 201 & 116 & 3.7 \\
\hline 24.312 & 3.658 & 184 & 123 & 2.6 \\
\hline 25.627 & 3.473 & 169 & 121 & 2.1 \\
\hline 26.630 & 3.345 & 2429 & 115 & 100 \\
\hline 27.085 & 3.290 & 186 & 124 & 2.7 \\
\hline 27.535 & 3.237 & 315 & 136 & 7.7 \\
\hline 27.786 & 3.208 & 647 & 169 & 20.7 \\
\hline 27.853 & 3.201 & 438 & 164 & 11.8 \\
\hline 27.996 & 3.185 & 634 & 154 & 20.7 \\
\hline 28.073 & 3.176 & 328 & 147 & 7.8 \\
\hline 29.419 & 3.034 & 183 & 145 & 1.6 \\
\hline 36.531 & 2.458 & 234 & 99 & 5.8 \\
\hline 36.639 & 2.451 & 170 & 98 & 3.1 \\
\hline 39.458 & 2.282 & 211 & 81 & 5.6 \\
\hline 39.561 & 2.276 & 138 & 81 & 2.5 \\
\hline 40.287 & 2.237 & 147 & 78 & 3.0 \\
\hline 41.884 & 2.155 & 108 & 79 & 1.3 \\
\hline 42.416 & 2.129 & 158 & 76 & 3.5 \\
\hline 42.539 & 2.123 & 121 & 76 & 1.9 \\
\hline 45.788 & 1.980 & 191 & 75 & 5.0 \\
\hline 45.901 & 1.975 & 132 & 74 & 2.5 \\
\hline 50.127 & 1.818 & 323 & 67 & 11.1 \\
\hline 50.255 & 1.814 & 194 & 66 & 5.5 \\
\hline 50.762 & 1.797 & 108 & 66 & 1.8 \\
\hline 54.866 & 1.672 & 157 & 69 & 3.8 \\
\hline 55.004 & 1.668 & 115 & 69 & 2.0 \\
\hline 59.942 & 1.542 & 272 & 69 & 8.8 \\
\hline 60.116 & 1.538 & 163 & 69 & 4.1 \\
\hline 61.646 & 1.503 & 196 & 69 & 5.5 \\
\hline 61.820 & 1.500 & 135 & 69 & 2.9 \\
\hline 63.974 & 1.454 & 92 & 66 & 1.1 \\
\hline 67.699 & 1.383 & 161 & 65 & 4.1 \\
\hline 67.919 & 1.379 & 135 & 65 & 3.0 \\
\hline 68.109 & 1.376 & 223 & 64 & 6.9 \\
\hline 68.298 & 1.372 & 189 & 64 & 5.4 \\
\hline 68.482 & 1.369 & 106 & 64 & 1.8 \\
\hline
\end{tabular}

$$
\lambda=2 d \sin \theta .
$$

The most intense peak occurred at a two theta value of 26.63 degrees and had an intensity of 2429 with an estimated background of 115 . The mineral identifications provided by the commercial software were not plausible (based on the known composition and absence of strong peaks expected for the suggested minerals) and no further analysis of the spectrum was done. Documentation of these results is presented for future comparisons with other samples of NIST SRM 2709a San Joaquin soil. 


\subsection{Soil Characterization by SEM}

A small amount of soil from Jar 1 was examined using a scanning electron microscope (SEM) to document the range of particle sizes in the soil samples. The photomicrographs in Figure 3 show a few larger particles, but a preponderance of 1-micrometer-sized particles. Clearly, the small particles provide the vast majority of surface area in the tests. While sieving the as-received soil to better constrain the particle size was considered initially, this was not done for the following reasons. The ASTM C1733 procedure does not specify a constrained size range; rather, it identifies a typical upper size limit of $2 \mathrm{~mm}$ to exclude gravel. It is reasoned that the majority of the surface area is provided by smaller particles and excluding particles larger than $2 \mathrm{~mm}$ simplifies test performance without contributing significant error. Since the test is conducted on a mass-soil basis, the size fraction will affect the test response. Therefore, it is crucial that a representative sample be used to ensure that the test response is representative of the material of interest. For the present purpose, the samples used in the tests are assumed to represent all of the material in the jar. The validity of this assumption is determined, in part, by the measured effect of the sample size on the test response, which is discussed in Section 3.4. In addition, the range of particle sizes of soil in the jars used in these tests is assumed to be the same as that of soils in other jars of SRM 2709a. Although performing a sieve analysis to quantify the size fractions was considered, this was not done due to the limited amount of soil that was available and the primary focus of this project being evaluation of the test method.

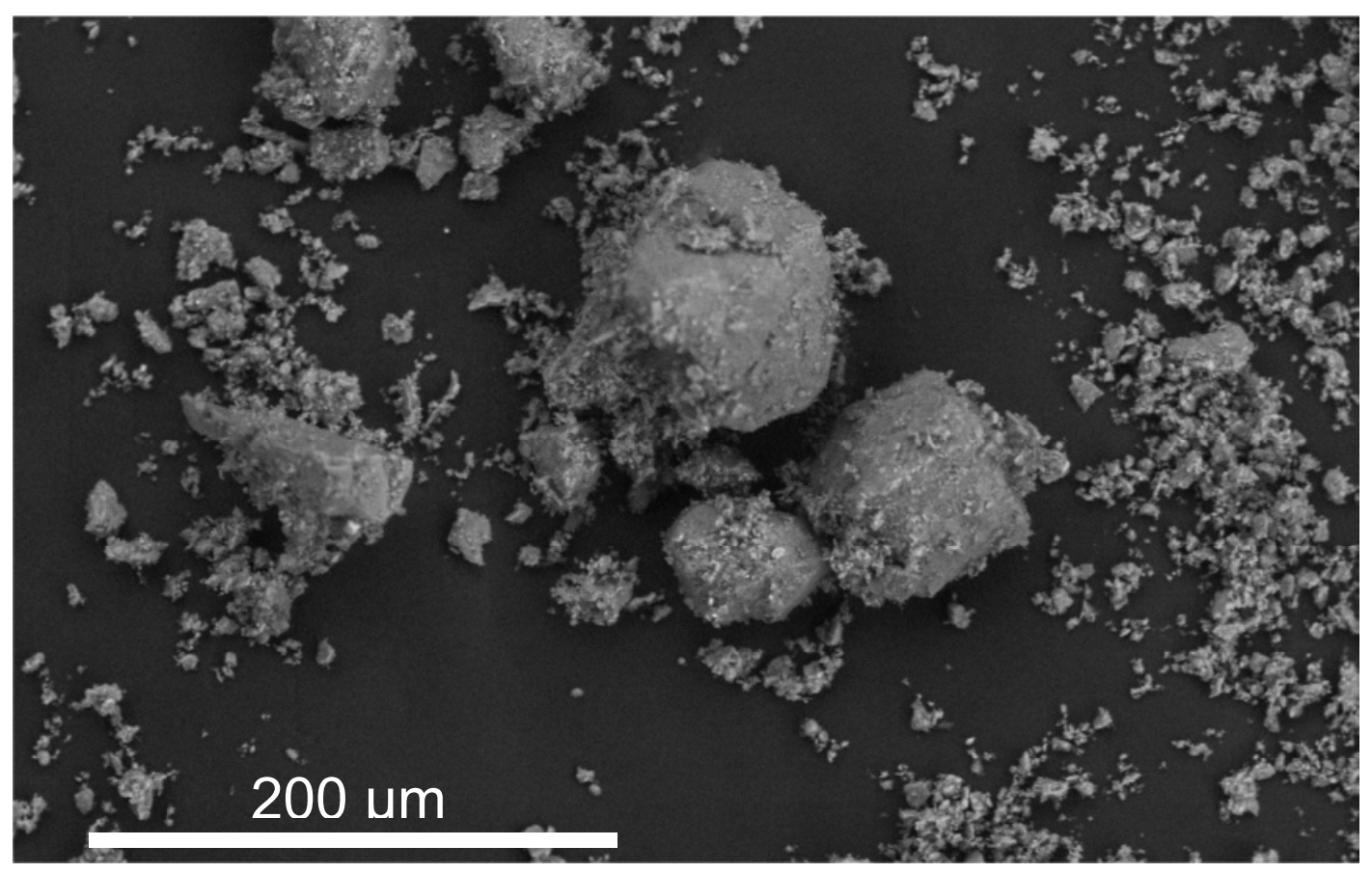

(a)

Figure 2. SEM photomicrographs of the San Joaquin soil from Jar 1 at (a) low, (b) moderate, and (c) high magnification. 


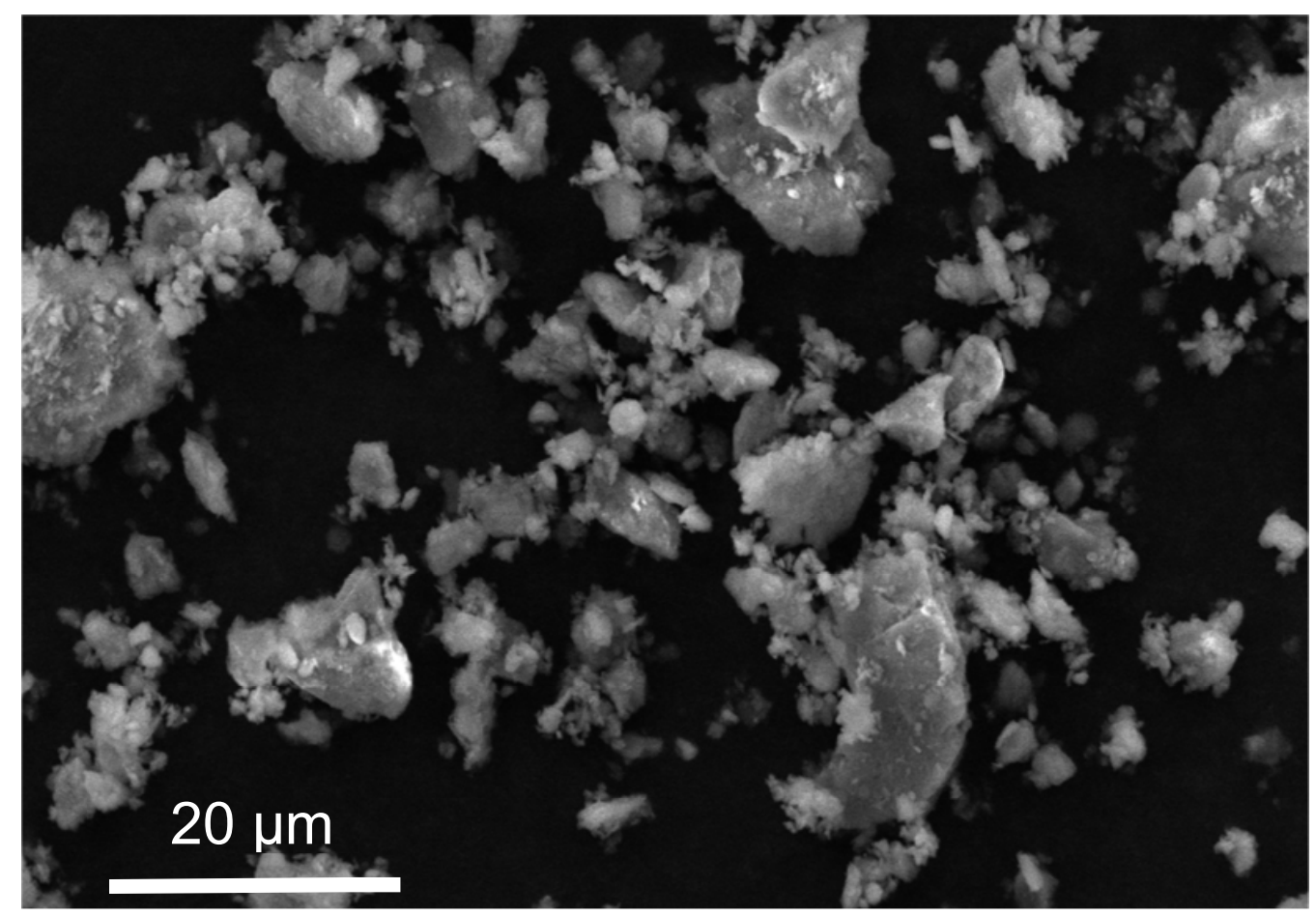

(b)

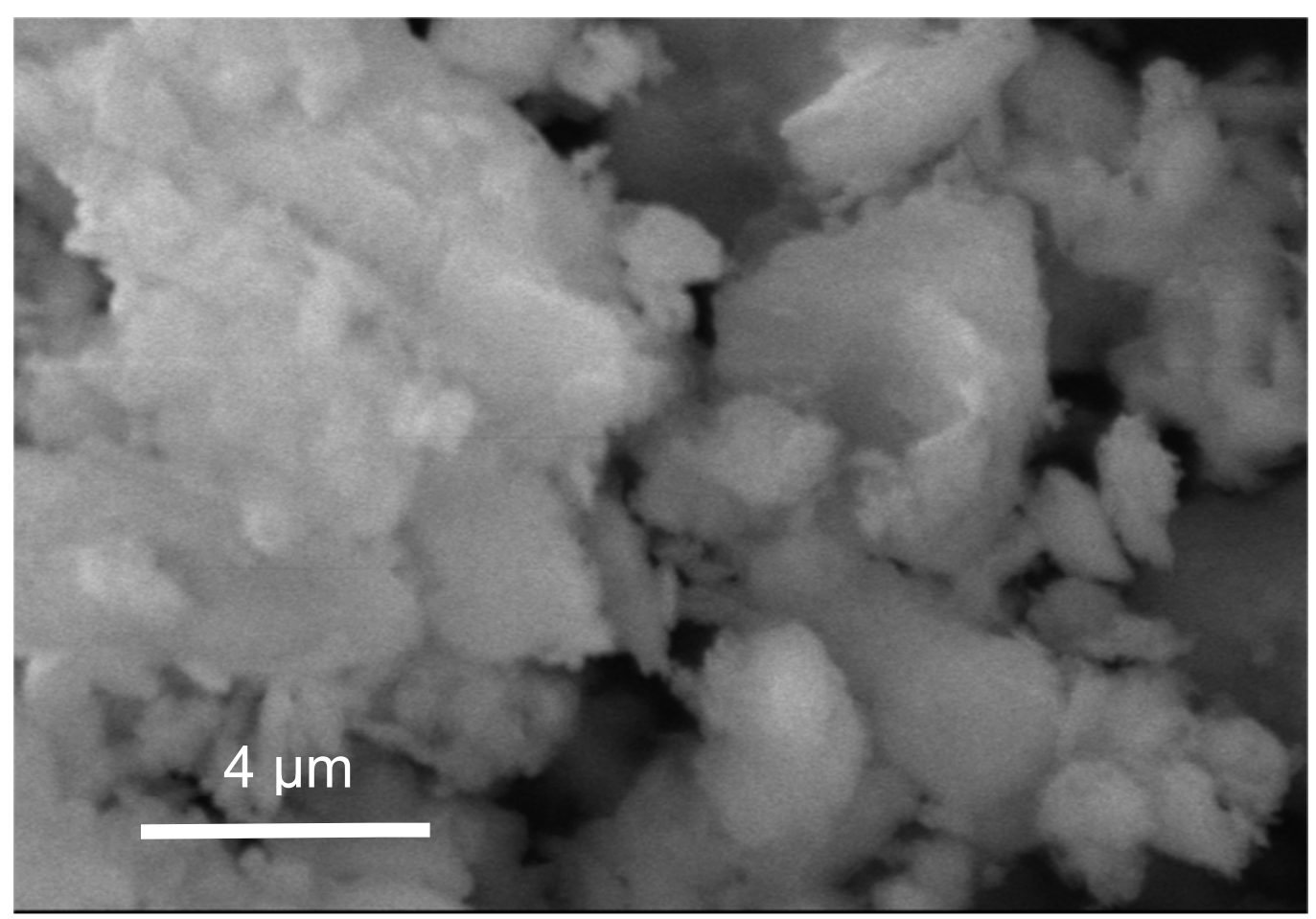

(c)

Figure 2. (cont.) 


\section{TEST RESULTS}

\subsection{Soil Blank Tests}

A series of blank tests were run to measure the amounts of Cs and $\mathrm{Sr}$ released from the soil into solution. Three tests were conducted with $0.50 \mathrm{~g}$ soil in $12.5 \mathrm{~g}$ demineralized water for about 1,3 , and 7 days. Soil from Jar 1 was used in these tests. The test data and results are given in Table 2. Calculations of final $\mathrm{pH}$, dilution factors, and dilution-corrected concentrations are discussed in Appendix B. The average solution concentrations for the three soil blank tests are $0.2 \times 10^{-9}$ molal Cs and $1.1 \times 10^{-6}$ molal Sr. From these measured concentrations, averages of $0.77 \mathrm{ng} \mathrm{Cs}$ and $2.47 \mu \mathrm{g}$ Sr were released per gram soil in the three soil blank tests. The release of $\mathrm{Cs}$ is negligible, but enough $\mathrm{Sr}$ is released to affect the test response.

Table 2. Data and results for soil blank tests

\begin{tabular}{|c|c|c|c|c|}
\hline Test Number & $\begin{array}{c}\text { Duration, } \\
\mathrm{h}\end{array}$ & $\begin{array}{c}\text { Mass Soil, } \\
\mathrm{g}\end{array}$ & $\begin{array}{c}\text { Mass DIW, } \\
\mathrm{g}\end{array}$ & Final pH \\
\hline SJ1-Blank-0 & 71.6 & 0.50 & 12.59 & 8.09 \\
\hline SJ1-Blank-1 & 23.6 & 0.50 & 12.55 & 8.04 \\
\hline SJ1-Blank-2 & 167.6 & 0.50 & 12.50 & 8.02 \\
\hline
\end{tabular}

\begin{tabular}{|c|c|c|c|c|}
\hline Test Number & $\begin{array}{c}\text { Solution Bottle, } \\
\mathrm{g}\end{array}$ & $\begin{array}{c}\text { + test solution, } \\
\mathrm{g}\end{array}$ & $\begin{array}{c}+\mathrm{DIW}+\mathrm{HNO}_{3}, \\
\mathrm{~g}\end{array}$ & Dilution Factor \\
\hline SJ1-Blank-0 & 11.19 & 22.89 & 27.25 & 1.37265 \\
\hline SJ1-Blank-1 & 11.11 & 22.37 & 22.42 & 1.00444 \\
\hline SJ1-Blank-2 & 11.19 & 22.42 & 22.48 & 1.00534 \\
\hline
\end{tabular}

\begin{tabular}{|c|c|c|c|c|}
\hline Test Number & $\begin{array}{c}\text { Measured Cs, } \\
\mu \mathrm{g} / \mathrm{L}\end{array}$ & $\begin{array}{c}\text { Measured Sr, } \\
\mu \mathrm{g} / \mathrm{L}\end{array}$ & $\begin{array}{c}\text { Dil.-corrected Cs, } \\
\mu \mathrm{g} / \mathrm{L}\end{array}$ & $\begin{array}{c}\text { Dil.-corrected Sr, } \\
\mu \mathrm{g} / \mathrm{L}\end{array}$ \\
\hline SJ1-Blank-0 & 0.0200 & 59.4 & 0.0275 & 81.5 \\
\hline SJ1-Blank-1 & 0.0242 & 89.0 & 0.0244 & 89.4 \\
\hline SJ1-Blank-2 & 0.0395 & 124 & 0.0397 & 125 \\
\hline
\end{tabular}

\subsection{Leachant Blank Tests}

Three solution blank tests were conducted with the nominal $1 \times 10^{-4} \underline{\mathrm{m}} \mathrm{Cs}$ A solution and $1 \times 10^{-4} \underline{\mathrm{m}} \mathrm{Sr} \mathrm{A}$ solution for 1, 2, and 7 days to evaluate the stability of the solutions. Single blank tests were later conducted with the leachants made with different $\mathrm{Cs}$ and $\mathrm{Sr}$ concentrations for duration of about 3 days. Those solutions were adjusted to a common $\mathrm{pH}$ value before use by adding small amounts of nitric acid or $\mathrm{NaOH}$ solutions. This was done to distinguish between the effects of time, concentration, and $\mathrm{pH}$. The test data are provided in Table 3. The dilution factors listed in Table 3 are due to dilution of the test solution by adding nitric acid. The $\mathrm{Cs}$ and $\mathrm{Sr}$ test solutions from tests run for the same duration were combined for analysis. Table 4 lists the solutions that were combined and the dilution factors that resulted from mixing the solutions. Calculations of final $\mathrm{pH}$, dilution factors, and dilution-corrected concentrations are discussed in Appendix B. 
Table 3. Data and results for leachant blank tests

\begin{tabular}{|c|c|c|c|c|}
\hline Test Number & $\begin{array}{c}\text { Duration, } \\
\mathrm{h}\end{array}$ & $\begin{array}{c}\text { Mass Soil, } \\
\mathrm{g}\end{array}$ & $\begin{array}{c}\text { Mass Leachant, } \\
\mathrm{g}\end{array}$ & Final $\mathrm{pH}$ \\
\hline Cs-A-Blank-1 & 24.62 & 0 & 12.53 & not measured \\
\hline Cs-A-Blank-2 & 48.20 & 0 & 12.49 & 8.61 \\
\hline Cs-A-Blank-3 & 168.37 & 0 & 12.63 & 8.46 \\
\hline Sr-A-Blank-1 & 24.62 & 0 & 12.56 & not measured \\
\hline Sr-A-Blank-2 & 48.20 & 0 & 12.51 & 8.36 \\
\hline Sr-A-Blank-3 & 168.37 & 0 & 12.50 & 8.39 \\
\hline SJ1-Cs-A2-0 & 74.87 & 0 & 12.51 & 8.56 \\
\hline SJ1-Cs-B-0 & 71.63 & 0 & 12.50 & 8.53 \\
\hline SJ1-Cs-C-0 & 71.63 & 0 & 12.51 & 8.40 \\
\hline SJ1-Cs-D-0 & 71.63 & 0 & 12.50 & 8.47 \\
\hline SJ1-Cs-E-0 & 71.63 & 0 & 2.50 & 8.44 \\
\hline SJ1-Cs-F-0 & 71.63 & 0 & 12.50 & 8.48 \\
\hline SJ1-Sr-A2-0 & 74.87 & 0 & 12.51 & 8.56 \\
\hline SJ1-Sr-B-0 & 78.93 & 0 & 12.51 & 8.10 \\
\hline SJ1-Sr-C-0 & 78.93 & 0 & 12.50 & 8.52 \\
\hline SJ1-Sr-D-0 & 78.93 & 0 & 12.50 & 8.52 \\
\hline SJ1-Sr-E-0 & 78.93 & 0 & 12.51 & 8.50 \\
\hline SJ1-Sr-F-0 & 78.93 & 0 & 12.50 & 8.50 \\
\hline SJ1-Sr-F-0 & 47.88 & 0 & 12.50 & 8.62 \\
\hline
\end{tabular}

\begin{tabular}{|c|c|c|c|c|}
\hline Test Number & $\begin{array}{c}\text { Solution Bottle, } \\
\mathrm{g}\end{array}$ & $\begin{array}{c}\text { Bottle + test } \\
\text { solution, }\end{array}$ & $\begin{array}{c}\text { Bottle + test solution } \\
+\mathrm{DIW}+\mathrm{HNO}_{3}, \mathrm{~g}\end{array}$ & Dilution Factor \\
\hline Cs-A-Blank-1 & 11.09 & 23.32 & 23.36 & 1.003 \\
\hline Cs-A-Blank-2 & 11.16 & 22.99 & 23.03 & 1.003 \\
\hline Cs-A-Blank-3 & 11.12 & 23.10 & 23.16 & 1.005 \\
\hline Sr-A-Blank-1 & 11.10 & 23.35 & 23.40 & 1.004 \\
\hline Sr-A-Blank-2 & 11.09 & 22.94 & 22.98 & 1.003 \\
\hline Sr-A-Blank-3 & 11.12 & 23.02 & 23.09 & 1.006 \\
\hline SJ1-Cs-A2-0 & 11.16 & 22.97 & 23.03 & 1.005 \\
\hline SJ1-Cs-B-0 & 11.17 & 22.82 & 22.88 & 1.005 \\
\hline SJ1-Cs-C-0 & 11.14 & 23.03 & 23.11 & 1.007 \\
\hline SJ1-Cs-D-0 & 11.16 & 22.9 & 22.93 & 1.003 \\
\hline SJ1-Cs-E-0 & 11.15 & 22.89 & 22.93 & 1.003 \\
\hline SJ1-Cs-F-0 & 11.19 & 22.94 & 23.00 & 1.005 \\
\hline SJ1-Sr-A2-0 & 11.16 & 22.97 & 23.03 & 1.005 \\
\hline SJ1-Sr-B-0 & 11.1 & 22.73 & 22.78 & 1.004 \\
\hline SJ1-Sr-C-0 & 11.21 & 22.87 & 22.94 & 1.006 \\
\hline SJ1-Sr-D-0 & 11.19 & 22.87 & 22.94 & 1.006 \\
\hline SJ1-Sr-E-0 & 11.17 & 22.91 & 22.94 & 1.003 \\
\hline SJ1-Sr-F-0 & 11.24 & 22.98 & 23.02 & 1.003 \\
\hline SJ1-Sr-F-0 & 11.11 & 22.82 & 22.92 & 1.009 \\
\hline
\end{tabular}

The solution results for the leachant blank tests are summarized in Table 5. These results show the Cs concentration to remain constant in blanks conducted through 7 days, but the $\mathrm{Sr}$ concentrations to decrease with time. The Cs solutions made for the concentration study were about $50 \%$ higher than the target concentrations and the $\mathrm{Sr}$ solutions were about $30 \%$ lower. The reason for this is not known, but the measured concentrations were used to calculate the $K_{\mathrm{d}}$ values in tests with soil. 
Table 4. Combination of leachant blank test solutions for analysis

\begin{tabular}{|c|c|c|}
\hline $\begin{array}{c}\text { Solution } \\
\text { Number }\end{array}$ & Solution 1 & Solution 2 \\
\hline Cs/Sr-A-Blank-1 & Cs-A-Blank-1 & Sr-A-Blank-1 \\
\hline Cs/Sr-A-Blank-2 & Cs-A-Blank-2 & Sr-A-Blank-2 \\
\hline Cs/Sr-A-Blank-3 & Cs-A-Blank-3 & Sr-A-Blank-3 \\
\hline SJ-A2-0 & SJ1-Cs-A2-0 & SJ1-Sr-A2-0 \\
\hline SJ-B-0 & SJ1-Cs-B-0 & SJ1-Sr-B-0 \\
\hline SJ-C-0 & SJ1-Cs-C-0 & SJ1-Sr-C-0 \\
\hline SJ-D-0 & SJ1-Cs-D-0 & SJ1-Sr-D-0 \\
\hline SJ-E-0 & SJ1-Cs-E-0 & SJ1-Sr-E-0 \\
\hline SJ-F-0 & SJ1-Cs-F-0 & SJ1-Sr-F-0 \\
\hline
\end{tabular}

\begin{tabular}{|c|c|c|c|c|c|}
\hline $\begin{array}{c}\text { Solution } \\
\text { Number }\end{array}$ & $\begin{array}{c}\text { Mixed Solutions } \\
\text { Bottle, g }\end{array}$ & $\begin{array}{c}\text { Bottle + Cs test } \\
\text { solution, g }\end{array}$ & $\begin{array}{c}\text { Bottle + Cs + Sr } \\
\text { test solution, g }\end{array}$ & $\begin{array}{c}\text { Cs Dilution } \\
\text { Factor }\end{array}$ & $\begin{array}{c}\text { Sr Dilution } \\
\text { Factor }\end{array}$ \\
\hline Cs/Sr-A-Blank-1 & 11.09 & 23.24 & 35.46 & 2.006 & 1.994 \\
\hline Cs/Sr-A-Blank-2 & 11.11 & 22.87 & 34.68 & 2.004 & 1.996 \\
\hline Cs/Sr-A-Blank-3 & 11.19 & 23.16 & 35.09 & 1.997 & 2.003 \\
\hline SJ-A2-0 & 11.12 & 22.98 & 34.80 & 1.997 & 2.003 \\
\hline SJ-B-0 & 11.16 & 22.79 & 34.34 & 1.993 & 2.007 \\
\hline SJ-C-0 & 11.18 & 23.11 & 34.77 & 1.977 & 2.023 \\
\hline SJ-D-0 & 11.19 & 22.86 & 34.57 & 2.003 & 1.997 \\
\hline SJ-E-0 & 11.19 & 22.88 & 34.6 & 2.003 & 1.997 \\
\hline SJ-F-0 & 11.23 & 22.98 & 34.66 & 1.994 & 2.006 \\
\hline SJ-F-0* & 11.11 & - & 22.92 & - & 1.003 \\
\hline
\end{tabular}

\subsection{Repeatability Tests}

Replicate tests were run using the $1.5 \times 10^{-4} \underline{\mathrm{m}} \mathrm{Cs}$ A solution and $0.50 \times 10^{-4} \underline{\mathrm{m}} \mathrm{Sr}$ A solution to measure the precision of the procedure for determining the $K_{\mathrm{d}}$ values following the ASTM C1733 procedure. Tests were conducted using $1.0 \mathrm{~g}$ soil and $25.0 \mathrm{~g}$ of solution. Five replicate tests were conducted with the Cs solution for both 1 and 2 days, and five replicate tests were conducted with the $\mathrm{Sr}$ solution for 1 day. All of the tests in the replicate test series were run with soil from the second container of San Joaquin soil and labeled with the prefix SJ2. Table 6 provides the test data. Note that the dilution factors due to the addition of concentrated $\mathrm{HNO}_{3}$ are neglected in subsequent calculations.

The test solutions from 1-day tests with the Cs solution and with the Sr solution with the same test indices were combined for analyses. The test solutions from the 2-day tests with the Cs solution were analyzed without mixing. Data for the combined solutions are given in Table 7. The mass of the empty solution bottle is given and then the accumulated masses of solution 1 and solution 2 are given. The solution masses were calculated by difference. The dilution factors due to mixing the solutions were calculated and are provided in the table. Calculations are discussed in Appendix B.

The analytical results for the combined and single solutions are summarized in Table 8 . These results indicate that an error occurred when the tests were initiated, namely, that the Cs A solution was used in the 1-day Sr tests and the Sr A solution was used in the 2-day Cs tests. (The Cs A solution was used correctly in the 1-day Cs tests.) The evidence is clear: First, no Cs was detected in SJ2-A-Y-6 through 10 but a significant concentration of $\mathrm{Sr}$ was measured. The $\mathrm{Sr}$ concentration is similar to that measured in other tests conducted with the same Sr solution used in this test series. Second, the Sr concentrations 
Table 5. Results for leachant blank tests

\begin{tabular}{|c|c|c|c|c|}
\hline Test Number & $\begin{array}{c}\text { Measured Cs, } \\
\mu \mathrm{g} / \mathrm{L}\end{array}$ & $\begin{array}{c}\text { Dil.-corrected Cs, } \\
\mu \mathrm{g} / \mathrm{L}\end{array}$ & $\begin{array}{c}\text { Measured Sr, } \\
\mu \mathrm{g} / \mathrm{L}\end{array}$ & $\begin{array}{c}\text { Dil.-corrected Sr, } \\
\mu \mathrm{g} / \mathrm{L}\end{array}$ \\
\hline Cs/Sr-A-Blank-1 & 12500 & 25070 & 5450 & 10900 \\
\hline Cs/Sr-A-Blank-2 & 12600 & 25250 & 3810 & 7600 \\
\hline Cs/Sr-A-Blank-3 & 12500 & 24960 & 2950 & 5910 \\
\hline SJ-A2-0 & 12300 & 24600 & 7360 & 14745 \\
\hline SJ-B-0 & 63200 & 125965 & 18000 & 36125 \\
\hline SJ-C-0 & 6140 & 12141 & 3860 & 7809 \\
\hline SJ-D-0 & 1260 & 2524 & 772 & 1541 \\
\hline SJ-E-0 & 135 & 270 & 82.8 & 165 \\
\hline SJ-F-0 & 3140 & 6261 & - & - \\
\hline SJ-F-0* & - & - & 3830 & 3840 \\
\hline
\end{tabular}

\begin{tabular}{|c|c|c|c|}
\hline Test Number & $\begin{array}{c}\text { Mass Cs in test solution, } \\
\mu \mathrm{g}\end{array}$ & $\begin{array}{c}\text { Measured Cs concentration, } \\
\text { molal }\end{array}$ & $\begin{array}{c}\text { Targeted Cs concentration, } \\
\text { molal }\end{array}$ \\
\hline Cs-A-Blank-1 & 316 & $1.49 \times 10^{-4}$ & $1.0 \times 10^{-4}$ \\
\hline Cs-A-Blank-2 & 317 & $1.50 \times 10^{-4}$ & $1.0 \times 10^{-4}$ \\
\hline Cs-A-Blank-3 & 317 & $1.48 \times 10^{-4}$ & $1.0 \times 10^{-4}$ \\
\hline SJ1-Cs-A2-0 & 309 & $1.46 \times 10^{-4}$ & $1.0 \times 10^{-4}$ \\
\hline SJ1-Cs-B-0 & 1583 & $7.48 \times 10^{-4}$ & $5.0 \times 10^{-4}$ \\
\hline SJ1-Cs-C-0 & 152.7 & $7.21 \times 10^{-5}$ & $5.0 \times 10^{-5}$ \\
\hline SJ1-Cs-D-0 & 31.7 & $1.50 \times 10^{-5}$ & $1.0 \times 10^{-5}$ \\
\hline SJ1-Cs-E-0 & 3.40 & $1.60 \times 10^{-6}$ & $1.0 \times 10^{-6}$ \\
\hline SJ1-Cs-F-0 & 78.69 & $3.72 \times 10^{-5}$ & $2.50 \times 10^{-5}$ \\
\hline
\end{tabular}

\begin{tabular}{|c|c|c|c|}
\hline Test Number & $\begin{array}{c}\text { Mass Sr in test solution, } \\
\mu \mathrm{g}\end{array}$ & $\begin{array}{c}\text { Measured Sr concentration, } \\
\text { molal }\end{array}$ & $\begin{array}{c}\text { Targeted Sr concentration, } \\
\text { molal }\end{array}$ \\
\hline Sr-A-Blank-1 & 137 & $5.14 \times 10^{-5}$ & $1.0 \times 10^{-4}$ \\
\hline Sr-A-Blank-2 & 95.5 & $3.59 \times 10^{-5}$ & $1.0 \times 10^{-4}$ \\
\hline Sr-A-Blank-3 & 74.1 & $2.79 \times 10^{-5}$ & $1.0 \times 10^{-4}$ \\
\hline SJ1-Sr-A2-0 & 186.24 & $6.97 \times 10^{-5}$ & $1.0 \times 10^{-4}$ \\
\hline SJ1-Sr-B-0 & 454.62 & $1.71 \times 10^{-4}$ & $5.0 \times 10^{-4}$ \\
\hline SJ1-Sr-C-0 & 99.09 & $3.69 \times 10^{-5}$ & $5.0 \times 10^{-5}$ \\
\hline SJ1-Sr-D-0 & 20.47 & $7.28 \times 10^{-6}$ & $1.0 \times 10^{-5}$ \\
\hline SJ1-Sr-E-0 & 3.22 & $7.80 \times 10^{-7}$ & $1.0 \times 10^{-6}$ \\
\hline SJ1-Sr-F-0 & - & - & $2.50 \times 10^{-5}$ \\
\hline SJ1-Sr-F-0* & 49.18 & $1.81 \times 10^{-5}$ & $2.50 \times 10^{-5}$ \\
\hline
\end{tabular}

measured in SJ2-A-Y-1 are consistent with the Sr concentrations measured in the soil blank tests. The results for tests SJ2-Cs-A-Y-6 through -10 are interpreted as being conducted with the Sr solution. The test numbers were retained to maintain traceability of test results. The measured Cs concentrations in the combined solutions SJ2-A-Y-1 through -5 reflect the combined results of tests conducted for 1 and 2 days. Although amounts cannot be attributed to each test solution, the volumes of each solution in the mixture are nearly equal and the test conditions are the same except for the reaction time. Other tests discussed below indicate that the test response is not sensitive to time between 1 and 2 days, so the combined solution provides a reliable measure of the repeatability of the test. Therefore, the results for the combined 1-day and 2-day test solutions are used with the added leachant and solid masses to calculate the distribution coefficient for Cs. Calculations are discussed in Appendix B. Propagation of uncertainties used to estimate uncertainty for plotted results is discussed in Appendix C. 
Table 6. Data for Replicate Tests

\begin{tabular}{|c|c|c|c|c|}
\hline Test Number & $\begin{array}{c}\text { Duration, } \\
\mathrm{h}\end{array}$ & $\begin{array}{c}\text { Mass Soil, } \\
\mathrm{g}\end{array}$ & $\begin{array}{c}\text { Mass Leachant, } \\
\mathrm{g}\end{array}$ & Final $\mathrm{pH}$ \\
\hline SJ2-Cs-A-Y-1 & 24.02 & 1.00 & 25.00 & 8.61 \\
\hline SJ2-Cs-A-Y-2 & 24.02 & 1.00 & 25.00 & 8.48 \\
\hline SJ2-Cs-A-Y-3 & 24.02 & 1.00 & 25.00 & 8.45 \\
\hline SJ2-Cs-A-Y-4 & 24.02 & 1.00 & 25.02 & 8.47 \\
\hline SJ2-Cs-A-Y-5 & 24.02 & 1.00 & 25.00 & 8.49 \\
\hline SJ2-Sr-A-Y-1 $^{\mathrm{a}}$ & 24.02 & 1.00 & 25.00 & 8.45 \\
\hline SJ2-Sr-A-Y-2 & 24.02 & 1.00 & 25.00 & 8.44 \\
\hline SJ2-Sr-A-Y-3 $^{\mathrm{a}}$ & 24.02 & 1.00 & 25.02 & 8.43 \\
\hline SJ2-Sr-A-Y-4 & 24.02 & 1.00 & 25.00 & 8.43 \\
\hline SJ2-Sr-A-Y-5 & 24.02 & 1.00 & 25.04 & 8.44 \\
\hline SJ2-Cs-A-Y-6 & 48.00 & 1.00 & 25.04 & 8.27 \\
\hline SJ2-Cs-A-Y-7 & 48.00 & 1.00 & 25.00 & 8.29 \\
\hline SJ2-Cs-A-Y-8 & 48.00 & 1.00 & 25.00 & 8.29 \\
\hline SJ2-Cs-A-Y-9 & 48.00 & 1.00 & 25.01 & 8.29 \\
\hline SJ2-Cs-A-Y-10 & 48.00 & 1.00 & 25.00 & 8.42 \\
\hline
\end{tabular}

\begin{tabular}{|c|c|c|c|c|}
\hline Test Number & $\begin{array}{l}\text { Solution Bottle, } \\
\mathrm{g}\end{array}$ & $\begin{array}{l}\text { Bottle + test } \\
\text { solution, } g\end{array}$ & $\begin{array}{l}\text { Bottle }+ \text { test solution } \\
+ \text { DIW }+\mathrm{HNO}_{3}, \mathrm{~g}\end{array}$ & Dilution Factor \\
\hline SJ2-Cs-A-Y-1 & 11.12 & 34.31 & 34.35 & 1.002 \\
\hline SJ2-Cs-A-Y-2 & 11.26 & 34.41 & 34.46 & 1.002 \\
\hline SJ2-Cs-A-Y-3 & 11.18 & 34.26 & 34.33 & 1.003 \\
\hline SJ2-Cs-A-Y-4 & 11.21 & 34.36 & 34.45 & 1.004 \\
\hline SJ2-Cs-A-Y-5 & 11.17 & 34.28 & 34.36 & 1.003 \\
\hline SJ2-Sr-A-Y-1 ${ }^{\text {a }}$ & 11.19 & 34.19 & 34.26 & 1.003 \\
\hline SJ2-Sr-A-Y-2 ${ }^{\mathrm{a}}$ & 11.20 & 34.24 & 34.34 & 1.004 \\
\hline SJ2-Sr-A-Y-3 ${ }^{\mathrm{a}}$ & 11.18 & 34.15 & 34.22 & 1.003 \\
\hline SJ2-Sr-A-Y-4 ${ }^{a}$ & 11.19 & 34.07 & 34.14 & 1.003 \\
\hline SJ2-Sr-A-Y-5 & 11.17 & 34.28 & 34.33 & 1.002 \\
\hline SJ2-Cs-A-Y-6 ${ }^{b}$ & 11.17 & 19.96 & 20.01 & 1.006 \\
\hline SJ2-Cs-A-Y-7 ${ }^{b}$ & 11.20 & 24.02 & 24.08 & 1.005 \\
\hline SJ2-Cs-A-Y- $8^{b}$ & 11.16 & 34.10 & 34.17 & 1.003 \\
\hline SJ2-Cs-A-Y-9 ${ }^{b}$ & 11.19 & 34.19 & 34.26 & 1.003 \\
\hline SJ2-Cs-A-Y-10 & 11.19 & 34.28 & 34.33 & 1.002 \\
\hline
\end{tabular}

${ }^{\mathrm{a}}$ Test was inadvertently conducted using Cs A solution.

${ }^{\mathrm{b}}$ Test was inadvertently conducted using $\mathrm{Sr}$ A solution.

Mean values are given for the amounts of $\mathrm{Cs}$ and $\mathrm{Sr}$ associated with the soil and in solution and for $K_{\mathrm{d}}$ values calculated from the replicate tests. Standard deviation values and relative standard deviation values are given of the solution concentration and $K_{\mathrm{d}}$ values, but not for the amounts on the soil. This is because the amounts taken up by the soil are calculated as the difference between the masses calculated from the concentrations in the initial solution (for which single values for $\mathrm{Cs}$ and $\mathrm{Sr}$ were used in all calculations) and each test solution. The average values from three blank test analyses are used to calculate the initial $\mathrm{Cs}$ and $\mathrm{Sr}$ contents in the initial solution (leachant). The relative standard deviations for the contaminant concentrations in the test solutions are less than the $10 \%$ uncertainty that is assumed for each measurement. Likewise, the precision of the replicate $K_{\mathrm{d}}$ measurements are within the propagated analytical uncertainty of about $15 \%$ for each value. 
Table 7. Combination of replicate test solutions for analysis

\begin{tabular}{|c|c|c|}
\hline $\begin{array}{c}\text { Solution } \\
\text { Number }\end{array}$ & Solution 1 & Solution 2 \\
\hline SJ2-A-Y-1 & SJ2-Cs-A-Y-1 & SJ2-Sr-A-Y-1 $^{\text {a }}$ \\
\hline SJ2-A-Y-2 & SJ2-Cs-A-Y-2 & SJ2-Sr-A-Y-2 $^{\text {a }}$ \\
\hline SJ2-A-Y-3 & SJ2-Cs-A-Y-3 & SJ2-Sr-A-Y-3 $^{\text {a }}$ \\
\hline SJ2-A-Y-4 & SJ2-Cs-A-Y-4 & SJ2-Sr-A-Y-4 $^{\text {a }}$ \\
\hline SJ2-A-Y-5 & SJ2-Cs-A-Y-5 & SJ2-Sr-A-Y-5 \\
\hline SJ2-A-Y-6 & SJ2-Cs-A-Y-6 & - \\
\hline SJ2-A-Y-7 & SJ2-Cs-A-Y-7 & - \\
\hline SJ2-A-Y-8 & SJ2-Cs-A-Y-8 & - \\
\hline SJ2-A-Y-9 & SJ2-Cs-A-Y-9 & - \\
\hline SJ2-A-Y-10 & SJ2-Cs-A-Y-10 & - \\
\hline
\end{tabular}

${ }^{a}$ Test was inadvertently conducted using Cs A solution.

${ }^{\mathrm{b}}$ Test was inadvertently conducted using Sr A solution.

\begin{tabular}{|c|c|c|c|c|c|}
\hline $\begin{array}{c}\text { Solution } \\
\text { Number }\end{array}$ & $\begin{array}{c}\text { Mixed Solution } \\
\text { Bottle, } \mathrm{g}\end{array}$ & $\begin{array}{c}\text { Bottle }+ \\
\text { Solution 1, g }\end{array}$ & $\begin{array}{c}\text { Bottle }+1+ \\
\text { Solution 2, }\end{array}$ & $\begin{array}{c}\text { Solution 1 } \\
\text { Dilution Factor }\end{array}$ & $\begin{array}{c}\text { Solution 2 } \\
\text { Dilution Factor }\end{array}$ \\
\hline SJ2-A-Y-1 & 11.19 & 22.68 & 34.35 & 2.016 & 1.985 \\
\hline SJ2-A-Y-2 & 11.17 & 22.50 & 33.95 & 2.011 & 1.990 \\
\hline SJ2-A-Y-3 & 11.16 & 22.88 & 35.41 & 2.069 & 1.935 \\
\hline SJ2-A-Y-4 & 11.21 & 22.94 & 34.27 & 1.966 & 2.035 \\
\hline SJ2-A-Y-5 & 11.21 & 22.43 & 33.71 & 2.008 & 1.992 \\
\hline SJ2-A-Y-6 & 11.17 & 19.96 & - & 1.006 & - \\
\hline SJ2-A-Y-7 & 11.20 & 24.02 & - & 1.005 & - \\
\hline SJ2-A-Y-8 & 11.16 & 34.10 & - & 1.003 & - \\
\hline SJ2-A-Y-9 & 11.19 & 34.19 & - & 1.003 & - \\
\hline SJ2-A-Y-10 & 11.19 & 34.28 & - & 1.002 & - \\
\hline
\end{tabular}

Figures $3 \mathrm{a}$ and $4 \mathrm{a}$ compare the amounts of $\mathrm{Cs}$ and $\mathrm{Sr}$ in the leachant with the masses taken up by the soil and remaining in solution, respectively, and Figures $3 \mathrm{~b}$ and $4 \mathrm{~b}$ compare the concentrations taken up by the soil and remaining in the solution, and the calculated $K_{\mathrm{d}}$ values. The variance and uncertainties in the amounts of Cs or Sr taken up by the soil and the $K_{\mathrm{d}}$ values are due to uncertainties in the leachant concentrations and the solution concentrations. As emphasized by the bar graphs, the calculated uptakes of both elements are the differences between large and small numbers. $K_{\mathrm{d}}$ is the ratio of a large number divided by a small number. The propagated uncertainties in the calculation of $K_{\mathrm{d}}$ is discussed in Appendix C. As displayed in Figures 3a and 4a, the uncertainties in the masses of Cs and $\mathrm{Sr}$ on the soil and in the solution in each test are greater than the variance between tests. Likewise, the variance in the calculated concentrations on the soil and $K_{\mathrm{d}}$ values for the replicate tests lie within the uncertainties of the values calculated for the individual tests.

The mean value of $K_{\mathrm{d}}(\mathrm{Cs})$ is $521.60 \mathrm{~mL} / \mathrm{g}$ with a standard deviation $(1 \sigma)$ of $16.45 \mathrm{~mL} / \mathrm{g}$, which gives a relative standard deviation of $3.13 \%$. The mean value of $K_{\mathrm{d}}(\mathrm{Sr})$ is $162.34 \mathrm{~mL} / \mathrm{g}$ with a standard deviation $(1 \sigma)$ of $8.34 \mathrm{~mL} / \mathrm{g}$, which gives a relative standard deviation of $5.13 \%$. The repeatability of the tests with a range defined by $\pm 2 \sigma$ lies within the propagated uncertainties for both Cs and Sr. 
Table 8. Results for replicate tests

\begin{tabular}{|c|c|c|c|c|}
\hline Solution Number & Measured Cs, $\mu \mathrm{g} / \mathrm{L}$ & Measured Sr, $\mu \mathrm{g} / \mathrm{L}$ & $\begin{array}{c}\text { Dil.-corrected Cs in } \\
\text { test solution, } \mu \mathrm{g} / \mathrm{L}\end{array}$ & $\begin{array}{c}\text { Dil.-corrected Sr in } \\
\text { test solution, } \mu \mathrm{g} / \mathrm{L}\end{array}$ \\
\hline SJ2-A-Y-1 & 1200 & 79.2 & 1200 & 157 \\
\hline SJ2-A-Y-2 & 1140 & 77.1 & 1140 & 153 \\
\hline SJ2-A-Y-3 & 1170 & 82.6 & 1170 & 160 \\
\hline SJ2-A-Y-4 & 1120 & 82.0 & 1120 & 167 \\
\hline SJ2-A-Y-5 & 1120 & 79.6 & 1120 & 159 \\
\hline SJ2-A-Y-6 & $<0.2$ & 1010 & 0 & 1013 \\
\hline SJ2-A-Y-7 & $<0.2$ & 1090 & 0 & 1095 \\
\hline SJ2-A-Y-8 & $<0.2$ & 1070 & 0 & 1073 \\
\hline SJ2-A-Y-9 & $<0.2$ & 1090 & 0 & 1093 \\
\hline SJ2-A-Y-10 & $<0.2$ & 1140 & 0 & 1142 \\
\hline
\end{tabular}

\begin{tabular}{|c|c|c|c|c|c|}
\hline Solution Number & $\begin{array}{c}\text { Mass Cs in test } \\
\text { solution, } \mu \mathrm{g}\end{array}$ & $\begin{array}{c}\text { Mass Sr in test } \\
\text { solution, } \mu \mathrm{g}\end{array}$ & $\begin{array}{c}\text { Leachant } \\
\text { Volume, } \mathrm{mL}\end{array}$ & $\begin{array}{c}\text { Mass Cs in } \\
\text { Leachant, } \mu \mathrm{g}\end{array}$ & $\begin{array}{c}\text { Mass Sr in } \\
\text { Leachant, } \mu \mathrm{g}\end{array}$ \\
\hline SJ2-A-Y-1 & 60.06 & - & 50.048 & 1256 & - \\
\hline SJ2-A-Y-2 & 57.06 & - & 50.048 & 1256 & - \\
\hline SJ2-A-Y-3 & 58.58 & - & 50.068 & 1256 & - \\
\hline SJ2-A-Y-4 & 56.08 & - & 50.069 & 1256 & - \\
\hline SJ2-A-Y-5 & 56.10 & - & 50.088 & 1257 & - \\
\hline SJ2-A-Y-6 & - & 25.28 & 24.954 & - & 202.8 \\
\hline SJ2-A-Y-7 & - & 27.27 & 24.914 & - & 202.5 \\
\hline SJ2-A-Y-8 & - & 26.74 & 24.914 & - & 202.5 \\
\hline SJ2-A-Y-9 & - & 27.25 & 24.924 & - & 202.6 \\
\hline SJ2-A-Y-10 & - & 28.46 & 24.914 & - & 202.5 \\
\hline
\end{tabular}

\begin{tabular}{|c|c|c|c|c|}
\hline Test Numbers & $\begin{array}{l}\text { Mass Cs on } \\
\text { soil, } \mu \mathrm{g}\end{array}$ & $\mu \mathrm{g}$ Cs/g soil & $\begin{array}{c}\text { Cs in test solution, } \\
\mu \mathrm{g} / \mathrm{mL}\end{array}$ & $\begin{array}{c}K_{\mathrm{d}}(\mathrm{Cs}), \\
\mathrm{mL} / \mathrm{g}\end{array}$ \\
\hline SJ2-Cs-A-Y-1 + SJ2-Sr-A-Y-1 ${ }^{\mathrm{a}}$ & 1196 & 597.9 & 1.20 & 498.3 \\
\hline SJ2-Cs-A-Y-2 + SJ2-Sr-A-Y-2 ${ }^{\mathrm{a}}$ & 1199 & 599.4 & 1.14 & 525.8 \\
\hline SJ2-Cs-A-Y-3 + SJ2-Sr-A-Y-3 ${ }^{a}$ & 1198 & 598.9 & 1.17 & 511.9 \\
\hline SJ2-Cs-A-Y-4 + SJ2-Sr-A-Y-4a & 1200 & 600.2 & 1.12 & 535.9 \\
\hline SJ2-Cs-A-Y-5 + SJ2-Sr-A-Y-5 & 1201 & 600.4 & 1.12 & 536.1 \\
\hline \multirow{2}{*}{\multicolumn{2}{|c|}{$\begin{array}{r}\text { Mean } \\
\text { Standard Deviation }\end{array}$}} & 599.42 & 1.150 & 521.60 \\
\hline & & - & 0.035 & 16.45 \\
\hline \multicolumn{2}{|c|}{ Relative Standard Deviation } & - & $3.01 \%$ & $3.13 \%$ \\
\hline
\end{tabular}

${ }^{\mathrm{a}}$ Test was inadvertently conducted using Cs A solution instead of Sr A solution.

\begin{tabular}{|c|c|c|c|c|}
\hline Test Number & $\begin{array}{c}\text { Mass Sr on } \\
\text { soil, } \mu \mathrm{g}\end{array}$ & $\mu \mathrm{g} \mathrm{Sr} / \mathrm{g}$ soil & $\begin{array}{c}\text { Sr in test solution, } \\
\mu \mathrm{g} / \mathrm{mL}\end{array}$ & $\begin{array}{c}K_{\mathrm{d}}(\mathrm{Sr}), \\
\mathrm{mL} / \mathrm{g}\end{array}$ \\
\hline SJ2-Cs-A-Y-6 & 178 & 178 & 1.01 & 175.2 \\
\hline SJ2-Cs-A-Y-7 $^{\mathrm{b}}$ & 175 & 175 & 1.09 & 160.1 \\
\hline SJ2-Cs-A-Y-8 $^{\mathrm{b}}$ & 176 & 176 & 1.07 & 163.8 \\
\hline SJ2-Cs-A-Y-9 $^{\mathrm{b}}$ & 175 & 175 & 1.09 & 160.4 \\
\hline SJ2-Cs-A-Y-10 $^{\mathrm{b}}$ & 174 & 174 & 1.14 & 152.3 \\
\hline \multicolumn{2}{r|r|}{ Standard Deviation } & 175.4 & 1.083 & 162.34 \\
\hline \multicolumn{2}{r|r|}{ Relative Standard Deviation } & - & 0.047 & 8.34 \\
\hline
\end{tabular}

${ }^{\mathrm{b}}$ Test was inadvertently conducted using $\mathrm{Sr}$ A solution instead of Cs A solution. 


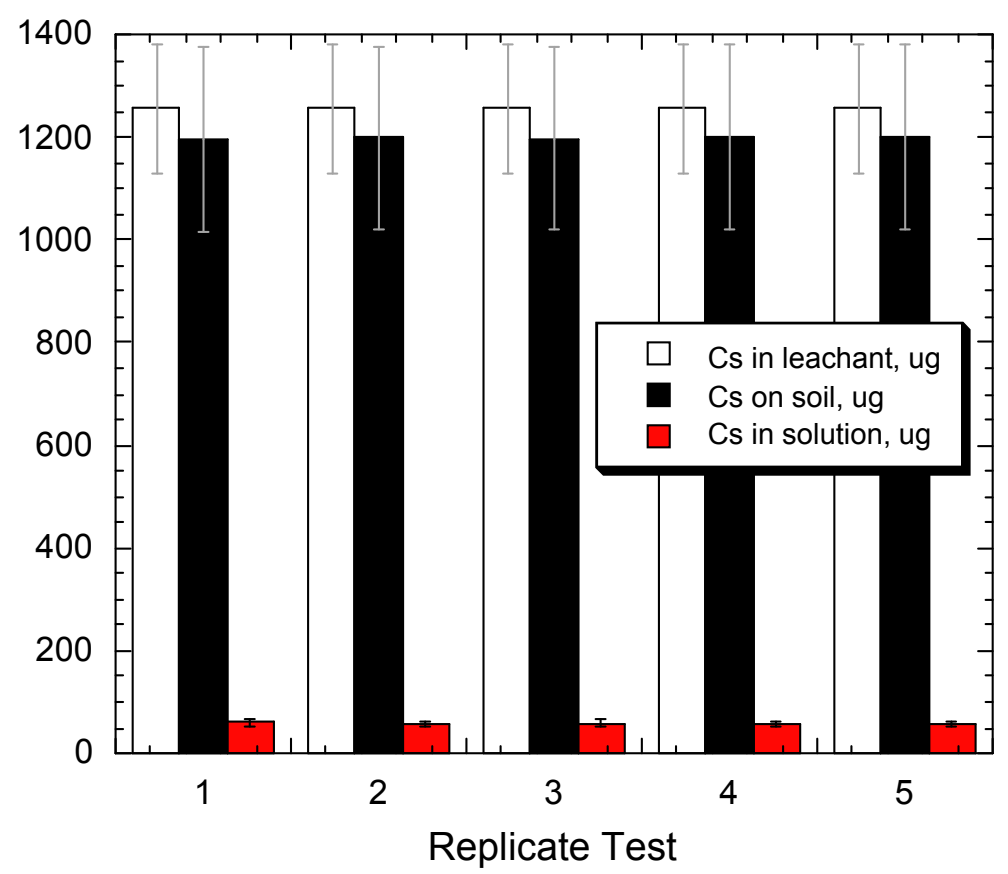

(a)

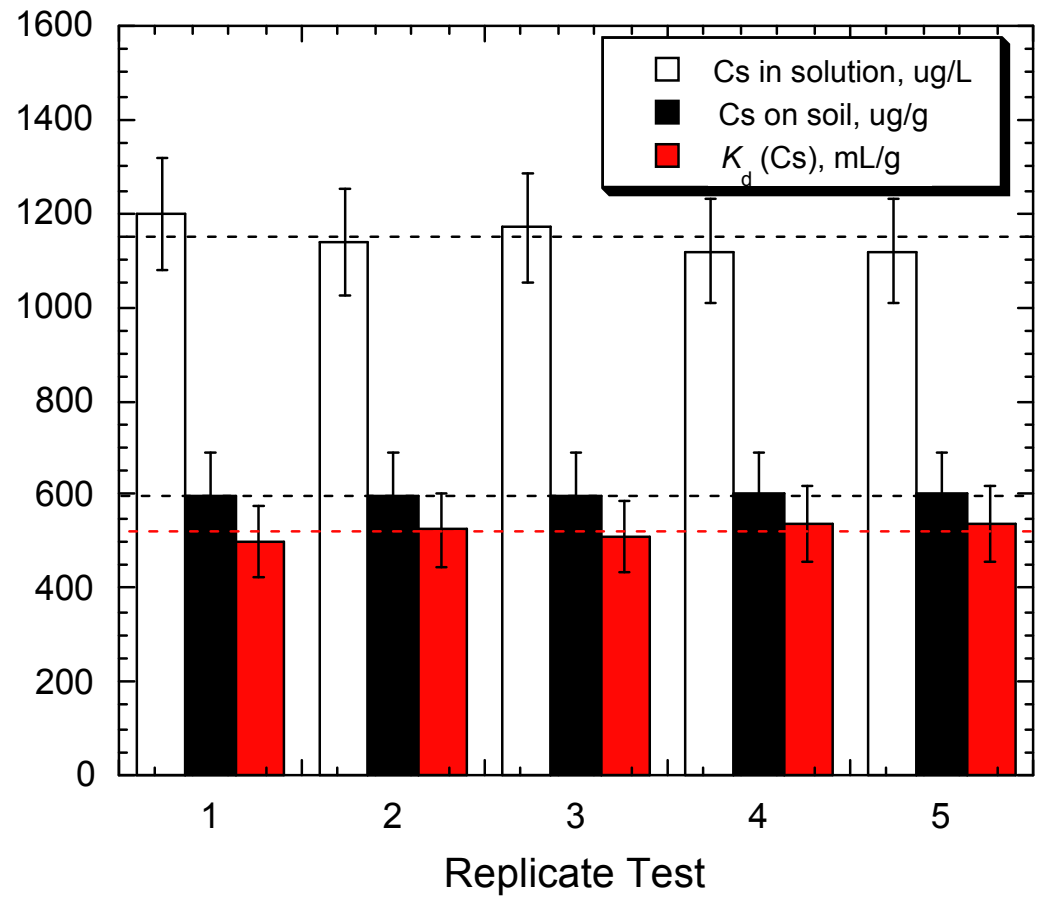

(b)

Figure 3. Results of replicate tests with Cs solution A: (a) masses of Cs in leachant, test solution, and taken up by soil, and (b) Cs concentrations in solution and on soil and $K_{\mathrm{d}}$ values. Dashed lines show mean values. 


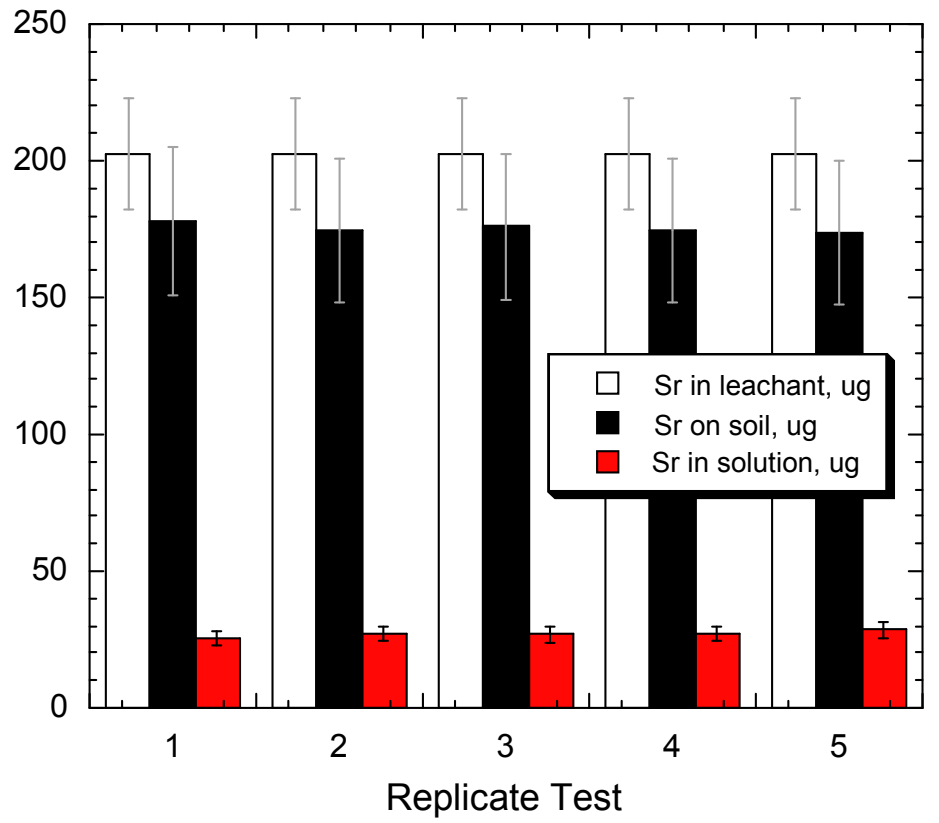

(a)

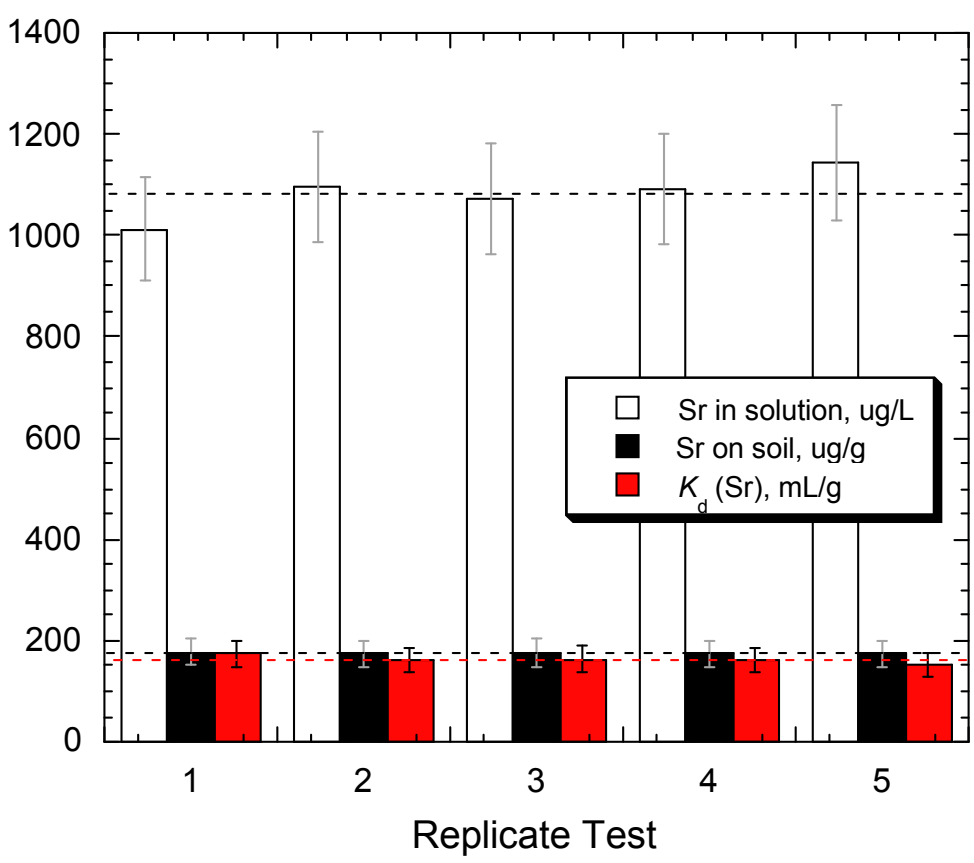

(b)

Figure 4. Results of replicate tests with $\mathrm{Sr}$ solution A: (a) masses of $\mathrm{Sr}$ in leachant, test solution, and taken up by soil, and (b) $\mathrm{Sr}$ concentrations in solution and on soil and $K_{\mathrm{d}}$ values. Dashed lines show mean values. 


\subsection{Effects of Scale Tests}

A series of tests was conducted in which the total amounts of soil and solution varied but the ratio was constant at the ASTM C1733-specified ratio of $1 \mathrm{~g}$ soil and $25 \mathrm{~g}$ groundwater. Four different masses of soil were used: $0.20,0.50,1.00$, and $1.50 \mathrm{~g}$. Tests were conducted with the Cs A solution. Table 9 provides the test data and Table 10 gives the results. Calculations are discussed in Appendix B. The mean value of $K_{\mathrm{d}}(\mathrm{Cs})$ is $568.2 .58 \mathrm{~mL} / \mathrm{g}$ with a standard deviation of $34.64 \mathrm{~mL} / \mathrm{g}$. The standard deviation is $6.16 \%$ of the mean. (Excluding the test with $0.20 \mathrm{~g}$ soil changes the mean to $547.73 \mathrm{~mL} / \mathrm{g}$ and reduces the standard deviation to $21.87 \mathrm{~mL} / \mathrm{g}$.) Figure 5 shows the $K_{\mathrm{d}}(\mathrm{Cs})$ values for all the soil masses with uncertainty bars drawn at $15 \%$ for the individual tests. The uncertainty in $K_{\mathrm{d}}(\mathrm{Cs})$ for the repeatability of the test based on the replicate tests is represented by the size of the diamonds. These results show a negative correlation between $K_{\mathrm{d}}(\mathrm{Cs})$ and the mass of soil. This is outside the uncertainty in the repeatability of the test method but within the uncertainties of the individual measurements.

Table 9. Data for tests conducted with different amounts of soil and solution

\begin{tabular}{|c|c|c|c|c|c|}
\hline Test Number & $\begin{array}{c}\text { Duration, } \\
\mathrm{h}\end{array}$ & $\begin{array}{c}\text { Mass Soil, } \\
\mathrm{g}\end{array}$ & $\begin{array}{c}\text { Mass } \\
\text { Leachant, } \mathrm{g}\end{array}$ & $\begin{array}{c}\text { Soil/Leachant } \\
\text { mass ratio }\end{array}$ & Final $\mathrm{pH}$ \\
\hline SJ2-Cs-A-Y-11 & 24.02 & 0.20 & 5.01 & 0.0399 & 8.48 \\
\hline SJ2-Cs-A-Y-12 & 24.02 & 0.50 & 12.50 & 0.0400 & 8.43 \\
\hline SJ2-Cs-A-Y-13 & 24.02 & 1.00 & 25.02 & 0.0400 & 8.67 \\
\hline SJ2-Cs-A-Y-14 & 24.02 & 1.50 & 37.50 & 0.0400 & 8.48 \\
\hline
\end{tabular}

\begin{tabular}{|c|c|c|c|c|}
\hline Test Number & $\begin{array}{c}\text { Solution Bottle, } \\
\mathrm{g}\end{array}$ & $\begin{array}{c}\text { Bottle }+\mathrm{Cs} \\
\text { solution, } \mathrm{g}\end{array}$ & $\begin{array}{c}\text { Bottle + Cs solution } \\
+\mathrm{DIW}+\mathrm{HNO}_{3}, \mathrm{~g}\end{array}$ & Cs Dilution Factor \\
\hline SJ2-Cs-A-Y-11 & 11.16 & 15.32 & 22.84 & 2.808 \\
\hline SJ2-Cs-A-Y-12 & 11.20 & 22.51 & 22.55 & 1.004 \\
\hline SJ2-Cs-A-Y-13 & 11.22 & 34.47 & 34.51 & 1.002 \\
\hline SJ2-Cs-A-Y-14 & 11.17 & 45.82 & 45.87 & 1.001 \\
\hline
\end{tabular}

Table 10. Results for tests conducted with different amounts of soil and solution

\begin{tabular}{|c|c|c|c|}
\hline Test Number & $\begin{array}{c}\text { Measured Cs, } \\
\mu \mathrm{g} / \mathrm{L}\end{array}$ & $\begin{array}{c}\text { Dil.-corrected Cs in } \\
\text { test solution, } \mu \mathrm{g} / \mathrm{L}\end{array}$ & $\begin{array}{c}\text { Mass Cs in test } \\
\text { solution, } \mu \mathrm{g}\end{array}$ \\
\hline SJ2-Cs-A-Y-11 & 356 & 999.5 & 5.035 \\
\hline SJ2-Cs-A-Y-12 & 1080 & 1085 & 13.63 \\
\hline SJ2-Cs-A-Y-13 & 1070 & 1073 & 27.00 \\
\hline SJ2-Cs-A-Y-14 & 1150 & 1154 & 43.49 \\
\hline
\end{tabular}

\begin{tabular}{|c|c|c|c|c|c|}
\hline Test Number & $\begin{array}{c}\text { Leachant } \\
\text { Volume, } \mathrm{mL}\end{array}$ & $\begin{array}{c}\text { Mass Cs in } \\
\text { Leachant, } \mu \mathrm{g}\end{array}$ & $\begin{array}{c}\text { Mass Cs on } \\
\text { soil, } \mu \mathrm{g}\end{array}$ & $\mu \mathrm{g}$ Cs/g soil & $\begin{array}{c}K_{\mathrm{d}}(\mathrm{Cs}) \\
\mathrm{mL} / \mathrm{g}\end{array}$ \\
\hline SJ2-Cs-A-Y-11 & 5.037 & 126.40 & 121.4 & 606.83 & 607.1 \\
\hline SJ2-Cs-A-Y-12 & 12.567 & 315.37 & 301.7 & 603.48 & 556.3 \\
\hline SJ2-Cs-A-Y-13 & 25.155 & 631.25 & 604.2 & 604.25 & 563.0 \\
\hline SJ2-Cs-A-Y-14 & 37.702 & 946.11 & 902.6 & 601.75 & 521.6 \\
\hline & & & & Mean & 562.01 \\
\hline \multicolumn{5}{|c|}{ Standard Deviation } & 34.12 \\
\hline \multicolumn{5}{|c|}{ Relative Standard Deviation } & $6.07 \%$ \\
\hline
\end{tabular}


The differences in the values for tests with different amounts of soil are all from differences in the measured solution concentration. The same value for the mass of $\mathrm{Cs}$ in the leachant is used in all calculations, so differences in the mass sorbed and $K_{\mathrm{d}}$ are due solely to differences in the measured solution concentrations. The uncertainty is slightly higher for the concentration measured in the $0.20 \mathrm{~g}$ test because that solution was diluted prior to analysis to provide sufficient solution. The data are plotted in Figure 5a to show almost all of the Cs is taken up by the soil and that the amount remaining in solution increases linearly with the mass of soil (and leachant) used in the test. The concentrations plotted in Figure $5 \mathrm{~b}$ show a slight increase in Cs in the solution, whereas the concentration on the soil, which is calculated from the difference in Cs contents in the leachant and test solution, remains essentially constant. The decrease in the value of $K_{\mathrm{d}}(\mathrm{Cs})$ with increasing soil masses reflects the increase in the

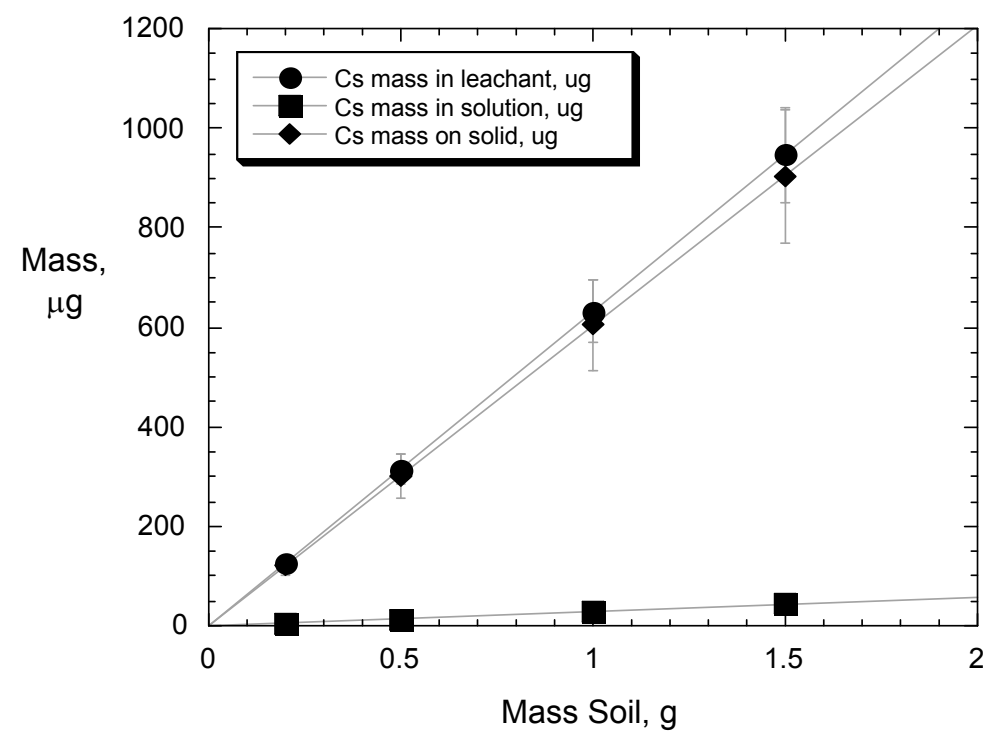

(a)

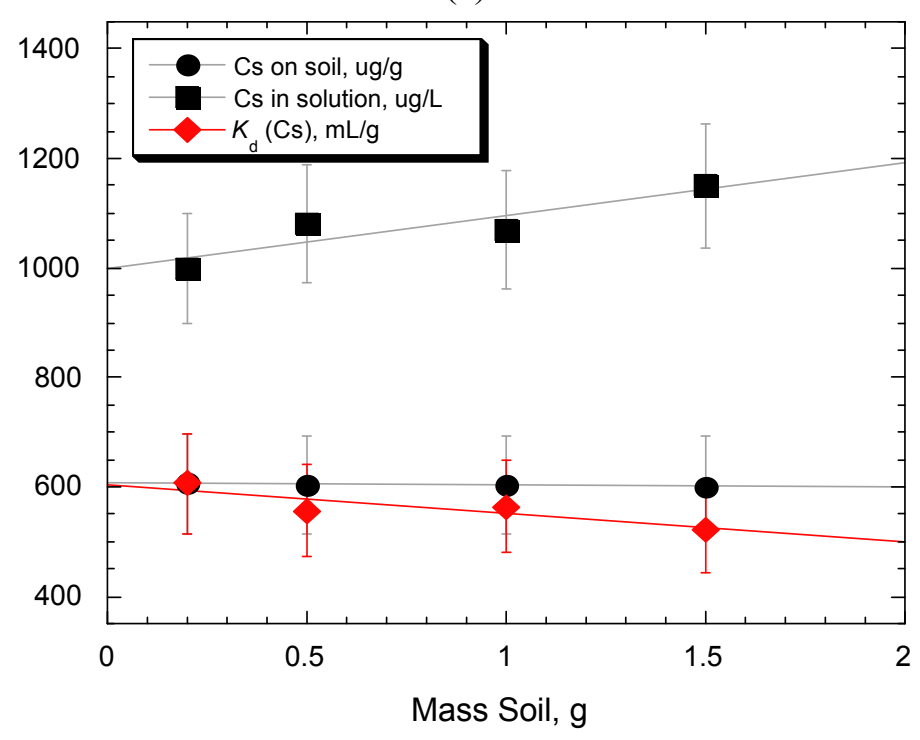

(b)

Figure 5. Results of tests with different amounts of soil and solution: (a) mass of Cs in leachant and in test solution or on soil vs. mass soil and (b) concentrations of Cs on soil and in solution, and $K_{\mathrm{d}}$ value, vs. mass soil. 
solution concentrations. Figure 6 presents the results of the replicate tests on a bar graph. Note the 1000fold difference in scale between the concentrations on the soil and in the test solution.

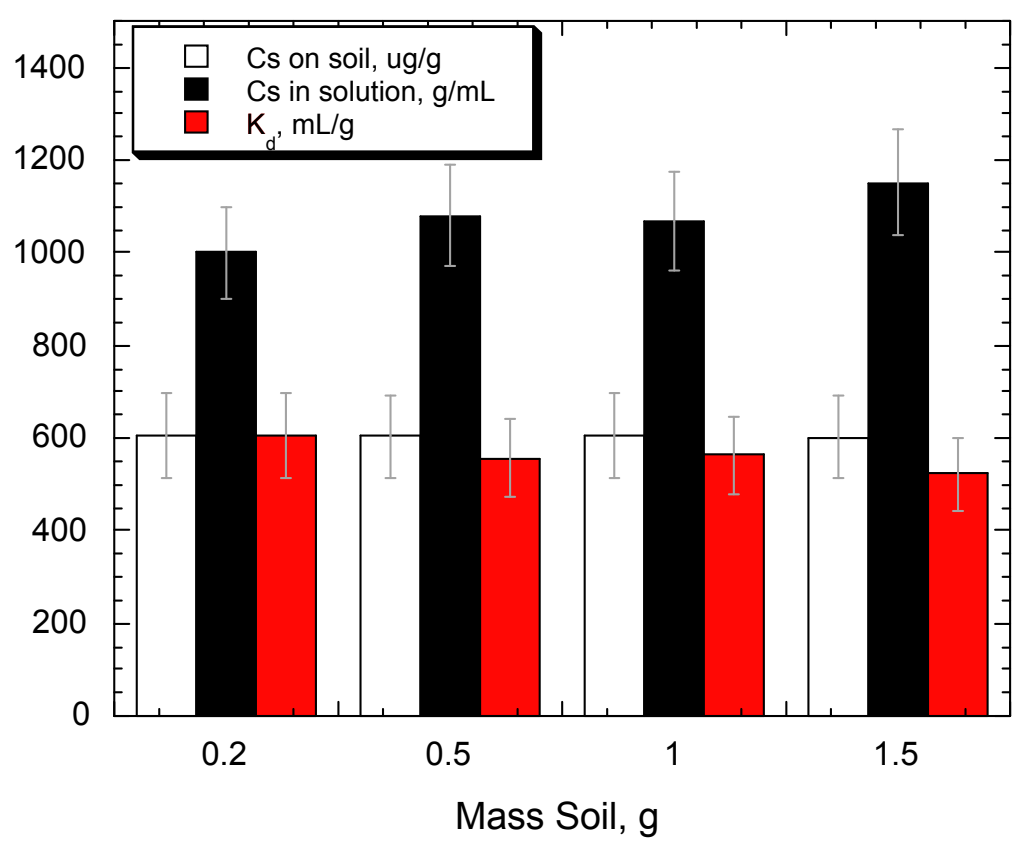

Figure 6. Results of tests with different amounts of soil and solution: comparison of concentrations of Cs on soil and in solution, and $K_{\mathrm{d}}$ values for different masses of soil

\subsection{Effects of Duration Tests}

A series of tests having durations between 15 minutes and about 7 days (167 hours and 46 minutes) was run to characterize the approach to equilibrium over time. The test data are provided in Table 11. Separate tests were conducted with about $0.5 \mathrm{~g}$ soil and $12.5 \mathrm{~g}$ of either the $1.4 \times 10^{-4} \underline{\mathrm{m}} \mathrm{Cs}$ A solution or the $0.50 \times 10^{-4} \mathrm{~m}$ Sr A solution. Tests SJ1-Cs-A-1 through SJ1-Cs-A-10 were conducted using soil from Jar 1 and tests SJ2-Cs-A-11 through SJ2-Cs-A-14 were conducted about 3 weeks later after it was determined that equilibrium had been reached within 7 days. The latter tests were conducted using soil from Jar 2. The solutions from tests run with $\mathrm{Cs}$ and $\mathrm{Sr}$ solutions for the same duration were combined for analysis. The data for the combined solutions are given in Table 12. The results are given in Table 13. Calculations are discussed in Appendix A.

Figures 7 and 8 show the amounts of cesium and strontium sorbed per gram of soil and remaining in solution as a function of time, along with the $K_{\mathrm{d}}$ values calculated for each test. Uncertainty bars are drawn at $10 \%$ for the solution concentrations and at $15 \%$ for the sorbed concentrations and at $15 \%$ for the $K_{\mathrm{d}}$ values: $10 \%$ uncertainty is conservative for solution analyses, the sorbed concentrations are calculated as the difference of two measured numbers and $K_{\mathrm{d}}$ values are calculated from the difference and quotient of two measured numbers. These plots show equilibrium was reached in less than two hours. In Figures $6 \mathrm{~b}$ and $7 \mathrm{~b}$, the uncertainty bars for $K_{\mathrm{d}}(\mathrm{Cs})$ and $K_{\mathrm{d}}(\mathrm{Sr})$ are drawn at $3 \%$ and $5 \%$, respectively, to represent the repeatability measured with the replicate tests. This shows the variance in $K_{\mathrm{d}}(\mathrm{Cs})$ to be about twice the measured testing repeatability, although there is no correlation with the duration. The variance in $K_{\mathrm{d}}(\mathrm{Sr})$ was within the measured testing repeatability for tests longer than 10 hours. 
Table 11. Data for tests conducted for different durations

\begin{tabular}{|c|c|c|c|c|c|}
\hline Test Number & $\begin{array}{c}\text { Duration, } \\
\mathrm{h}\end{array}$ & $\begin{array}{c}\text { Mass Soil, } \\
\mathrm{g}\end{array}$ & $\begin{array}{c}\text { Mass } \\
\text { Leachant, } \mathrm{g}\end{array}$ & $\begin{array}{c}\text { Soil/Leachant } \\
\text { mass ratio }\end{array}$ & Final $\mathrm{pH}$ \\
\hline SJ1-Cs-A-1 & 6.90 & 0.50 & 12.52 & 0.0399 & not measured \\
\hline SJ1-Cs-A-2 & 30.85 & 0.50 & 12.50 & 0.0400 & 8.32 \\
\hline SJ1-Cs-A-3 & 54.12 & 0.50 & 12.51 & 0.0400 & 8.27 \\
\hline SJ1-Cs-A-4 & 24.02 & 0.50 & 12.50 & 0.0400 & not measured \\
\hline SJ1-Cs-A-5 & 47.97 & 0.50 & 12.50 & 0.0400 & 8.32 \\
\hline SJ1-Cs-A-6 & 71.63 & 0.50 & 12.50 & 0.0400 & 8.37 \\
\hline SJ1-Cs-A-7 & 143.70 & 0.50 & 12.51 & 0.0400 & 8.30 \\
\hline SJ1-Cs-A-8 & 167.77 & 0.50 & 12.51 & 0.0400 & 8.44 \\
\hline SJ1-Cs-A-9 & 95.82 & 0.50 & 12.50 & 0.0400 & 8.47 \\
\hline SJ1-Cs-A-10 & 119.90 & 0.50 & 12.50 & 0.0400 & 8.52 \\
\hline SJ2-Cs-A-11 & 0.27 & 0.50 & 12.50 & 0.0400 & 8.69 \\
\hline SJ2-Cs-A-12 & 0.52 & 0.50 & 12.51 & 0.0400 & 8.54 \\
\hline SJ2-Cs-A-13 & 1.00 & 0.50 & 12.50 & 0.0400 & 8.43 \\
\hline SJ2-Cs-A-14 & 2.00 & 0.50 & 12.53 & 0.0399 & 8.47 \\
\hline
\end{tabular}

\begin{tabular}{|c|c|c|c|c|c|}
\hline Test Number & $\begin{array}{c}\text { Duration, } \\
\mathrm{h}\end{array}$ & $\begin{array}{c}\text { Mass Soil, } \\
\mathrm{g}\end{array}$ & $\begin{array}{c}\text { Mass } \\
\text { Leachant, } \mathrm{g}\end{array}$ & $\begin{array}{c}\text { Soil/Leachant } \\
\text { mass ratio }\end{array}$ & Final $\mathrm{pH}$ \\
\hline SJ1-Sr-A-1 & 6.62 & 0.50 & 12.53 & 0.0399 & not measured \\
\hline SJ1-Sr-A-2 & 30.57 & 0.50 & 12.54 & 0.0399 & 8.27 \\
\hline SJ1-Sr-A-3 & 53.83 & 0.50 & 12.50 & 0.0400 & 8.26 \\
\hline SJ1-Sr-A-4 & 23.78 & 0.50 & 12.51 & 0.0400 & not measured \\
\hline SJ1-Sr-A-5 & 47.73 & 0.50 & 12.50 & 0.0400 & 8.31 \\
\hline SJ1-Sr-A-6 & 71.00 & 0.50 & 12.50 & 0.0400 & 8.23 \\
\hline SJ1-Sr-A-7 & 143.47 & 0.50 & 12.52 & 0.0399 & 8.37 \\
\hline SJ1-Sr-A-8 & 167.63 & 0.50 & 12.51 & 0.0400 & 8.37 \\
\hline SJ1-Sr-A-9 & 95.82 & 0.50 & 12.50 & 0.0400 & 8.42 \\
\hline SJ1-Sr-A-10 & 119.90 & 0.50 & 12.50 & 0.0400 & 8.46 \\
\hline SJ2-Sr-A-11 & 0.25 & 0.50 & 12.50 & 0.0400 & 8.42 \\
\hline SJ2-Sr-A-12 & 0.50 & 0.50 & 12.50 & 0.0400 & 8.31 \\
\hline SJ2-Sr-A-13 & 1.00 & 0.50 & 12.50 & 0.0400 & 8.35 \\
\hline SJ2-Sr-A-14 & 2.00 & 0.50 & 12.50 & 0.0400 & 8.38 \\
\hline
\end{tabular}

\begin{tabular}{|c|c|c|c|c|}
\hline Test Number & $\begin{array}{c}\text { Solution Bottle, } \\
\mathrm{g}\end{array}$ & $\begin{array}{c}\text { Bottle }+ \text { Cs test } \\
\text { solution, } \mathrm{g}\end{array}$ & $\begin{array}{c}\text { Bottle }+ \text { Cs test solution } \\
+\mathrm{DIW}+\mathrm{HNO}_{3}, \mathrm{~g}\end{array}$ & Dilution Factor \\
\hline SJ1-Cs-A-1 & 11.20 & 22.64 & 22.68 & 1.003 \\
\hline SJ1-Cs-A-2 & 11.16 & 22.39 & 22.44 & 1.004 \\
\hline SJ1-Cs-A-3 & 11.20 & 22.61 & 22.66 & 1.004 \\
\hline SJ1-Cs-A-4 & 11.14 & 22.50 & 22.54 & 1.004 \\
\hline SJ1-Cs-A-5 & 11.10 & 22.42 & 22.48 & 1.005 \\
\hline SJ1-Cs-A-6 & 11.14 & 22.48 & 22.52 & 1.004 \\
\hline SJ1-Cs-A-7 & 11.13 & 22.30 & 22.34 & 1.004 \\
\hline SJ1-Cs-A-8 & 11.23 & 22.49 & 22.55 & 1.005 \\
\hline SJ1-Cs-A-9 & 11.13 & 22.28 & 22.32 & 1.004 \\
\hline SJ1-Cs-A-10 & 11.18 & 22.43 & 22.48 & 1.004 \\
\hline SJ2-Cs-A-11 & 11.12 & 22.54 & 22.61 & 1.006 \\
\hline SJ2-Cs-A-12 & 11.20 & 22.55 & 22.64 & 1.008 \\
\hline SJ2-Cs-A-13 & 11.22 & 22.63 & 22.69 & 1.005 \\
\hline SJ2-Cs-A-14 & 11.16 & 22.55 & 22.63 & 1.007 \\
\hline
\end{tabular}




\begin{tabular}{|c|c|c|c|c|}
\hline Test Number & $\begin{array}{c}\text { Solution Bottle, } \\
\mathrm{g}\end{array}$ & $\begin{array}{c}\text { Bottle }+ \text { Sr test } \\
\text { solution, } \mathrm{g}\end{array}$ & $\begin{array}{c}\text { Bottle }+ \text { Sr solution }+ \\
\mathrm{DIW}+\mathrm{HNO}_{3}, \mathrm{~g}\end{array}$ & Dilution Factor \\
\hline SJ1-Sr-A-1 & 11.17 & 22.70 & 22.74 & 1.003 \\
\hline SJ1-Sr-A-2 & 11.16 & 22.55 & 22.58 & 1.003 \\
\hline SJ1-Sr-A-3 & 11.13 & 22.43 & 22.48 & 1.004 \\
\hline SJ1-Sr-A-4 & 11.15 & 22.68 & 22.73 & 1.004 \\
\hline SJ1-Sr-A-5 & 11.12 & 22.36 & 22.42 & 1.005 \\
\hline SJ1-Sr-A-6 & 11.11 & 22.37 & 22.42 & 1.004 \\
\hline SJ1-Sr-A-7 & 11.08 & 22.29 & 22.33 & 1.004 \\
\hline SJ1-Sr-A-8 & 11.11 & 22.36 & 22.41 & 1.004 \\
\hline SJ1-Sr-A-9 & 11.17 & 22.34 & 22.38 & 1.004 \\
\hline SJ1-Sr-A-10 & 11.11 & 22.30 & 22.35 & 1.004 \\
\hline SJ2-Sr-A-11 & 11.17 & 22.45 & 22.51 & 1.005 \\
\hline SJ2-Sr-A-12 & 11.16 & 22.56 & 22.63 & 1.006 \\
\hline SJ2-Sr-A-13 & 11.24 & 22.54 & 22.60 & 1.005 \\
\hline SJ2-Sr-A-14 & 11.13 & 22.46 & 22.54 & 1.007 \\
\hline
\end{tabular}

Table 12. Combination of test solutions for tests conducted for different durations

\begin{tabular}{|c|c|c|c|c|c|}
\hline $\begin{array}{c}\text { Solution } \\
\text { Number }\end{array}$ & Solution 1 & Solution 2 & $\begin{array}{c}\text { Solution } \\
\text { Number }\end{array}$ & Solution 1 & Solution 2 \\
\hline SJ-A-1 & SJ1-Cs-A-1 & SJ1-Sr-A-1 & SJ-A-8 & SJ1-Cs-A-8 & SJ1-Sr-A-8 \\
\hline SJ-A-2 & SJ1-Cs-A-2 & SJ1-Sr-A-2 & SJ-A-9 & SJ1-Cs-A-9 & SJ1-Sr-A-9 \\
\hline SJ-A-3 & SJ1-Cs-A-3 & SJ1-Sr-A-3 & SJ-A-10 & SJ1-Cs-A-10 & SJ1-Sr-A-10 \\
\hline SJ-A-4 & SJ1-Cs-A-4 & SJ1-Sr-A-4 & SJ-A-11 & SJ2-Cs-A-11 & SJ2-Sr-A-11 \\
\hline SJ-A-5 & SJ1-Cs-A-5 & SJ1-Sr-A-5 & SJ-A-12 & SJ2-Cs-A-12 & SJ2-Sr-A-12 \\
\hline SJ-A-6 & SJ1-Cs-A-6 & SJ1-Sr-A-6 & SJ-A-13 & SJ2-Cs-A-13 & SJ2-Sr-A-13 \\
\hline SJ-A-7 & SJ1-Cs-A-7 & SJ1-Sr-A-7 & SJ-A-14 & SJ2-Cs-A-14 & SJ2-Sr-A-14 \\
\hline
\end{tabular}

\begin{tabular}{|c|c|c|c|c|c|}
\hline Test Number & $\begin{array}{c}\text { Mixed Solution } \\
\text { Bottle, } \mathrm{g}\end{array}$ & $\begin{array}{c}\text { Bottle }+ \text { Cs } \\
\text { test solution, } \mathrm{g}\end{array}$ & $\begin{array}{c}\text { Bottle + Cs + Sr } \\
\text { test solution, }\end{array}$ & $\begin{array}{c}\text { Cs Dilution } \\
\text { Factor }\end{array}$ & $\begin{array}{c}\text { Sr Dilution } \\
\text { Factor }\end{array}$ \\
\hline SJ-A-1 & 11.16 & 22.48 & 33.71 & 1.992 & 2.008 \\
\hline SJ-A-2 & 11.08 & 22.17 & 33.44 & 2.016 & 1.984 \\
\hline SJ-A-3 & 11.12 & 22.36 & 33.49 & 1.990 & 2.010 \\
\hline SJ-A-4 & 11.14 & 22.37 & 33.82 & 2.020 & 1.981 \\
\hline SJ-A-5 & 11.17 & 22.27 & 33.34 & 1.997 & 2.003 \\
\hline SJ-A-6 & 11.17 & 22.36 & 33.49 & 1.995 & 2.005 \\
\hline SJ-A-7 & 11.16 & 22.18 & 33.18 & 1.998 & 2.002 \\
\hline SJ-A-8 & 11.07 & 22.12 & 33.27 & 2.009 & 1.991 \\
\hline SJ-A-9 & 11.09 & 22.02 & 33.04 & 2.008 & 1.992 \\
\hline SJ-A-10 & 11.10 & 22.10 & 33.08 & 1.998 & 2.002 \\
\hline SJ-A-11 & 11.18 & 22.55 & 33.80 & 1.989 & 2.011 \\
\hline SJ-A-12 & 11.25 & 22.58 & 33.96 & 2.004 & 1.996 \\
\hline SJ-A-13 & 11.19 & 22.54 & 33.76 & 1.989 & 2.012 \\
\hline SJ-A-14 & 11.18 & 22.47 & 33.79 & 2.003 & 1.997 \\
\hline
\end{tabular}


Table 13. Results for tests conducted for different durations

\begin{tabular}{|c|c|c|c|c|}
\hline Test Number & $\begin{array}{c}\text { Measured Cs, } \\
\mu \mathrm{g} / \mathrm{L}\end{array}$ & $\begin{array}{c}\text { Dil.-corrected Cs, } \\
\mu \mathrm{g} / \mathrm{L}\end{array}$ & $\begin{array}{c}\text { Cs in test solution, } \\
\mu \mathrm{g}\end{array}$ & $\begin{array}{c}\text { Cs in test solution, } \\
\mu \mathrm{g} / \mathrm{mL}\end{array}$ \\
\hline SJ-A-1 & 510 & 1016 & 12.79 & 1.016 \\
\hline SJ-A-2 & 518 & 1044 & 13.13 & 1.044 \\
\hline SJ-A-3 & 565 & 1124 & 14.14 & 1.124 \\
\hline SJ-A-4 & 519 & 1048 & 13.17 & 1.048 \\
\hline SJ-A-5 & 516 & 1031 & 12.95 & 1.031 \\
\hline SJ-A-6 & 528 & 1053 & 13.24 & 1.053 \\
\hline SJ-A-7 & 552 & 1103 & 13.87 & 1.103 \\
\hline SJ-A-8 & 469 & 942.2 & 11.85 & 0.9422 \\
\hline SJ-A-9 & 542 & 1088 & 13.68 & 1.088 \\
\hline SJ-A-10 & 583 & 1165 & 14.64 & 1.165 \\
\hline SJ-A-11 & 507 & 1009 & 12.68 & 1.009 \\
\hline SJ-A-12 & 530 & 1062 & 13.36 & 1.062 \\
\hline SJ-A-13 & 585 & 1163 & 14.62 & 1.163 \\
\hline SJ-A-14 & 560 & 1121 & 14.13 & 1.121 \\
\hline
\end{tabular}

\begin{tabular}{|c|c|c|c|c|}
\hline Test Number & $\begin{array}{c}\text { Measured Sr, } \\
\mu \mathrm{g} / \mathrm{L}\end{array}$ & $\begin{array}{c}\text { Dil.-corrected Sr, } \\
\mu \mathrm{g} / \mathrm{L}\end{array}$ & $\begin{array}{c}\text { Sr in test solution, } \\
\mu \mathrm{g}\end{array}$ & $\begin{array}{c}\text { Sr in test solution, } \\
\mu \mathrm{g} / \mathrm{mL}\end{array}$ \\
\hline SJ-A-1 & 465 & 933.7 & 11.74 & 0.9337 \\
\hline SJ-A-2 & 492 & 976.1 & 12.28 & 0.9761 \\
\hline SJ-A-3 & 489 & 982.8 & 12.33 & 0.9828 \\
\hline SJ-A-4 & 513 & 1016 & 12.76 & 1.016 \\
\hline SJ-A-5 & 480 & 961.3 & 12.06 & 0.9613 \\
\hline SJ-A-6 & 488 & 978.6 & 12.28 & 0.9786 \\
\hline SJ-A-7 & 506 & 1013 & 12.73 & 1.013 \\
\hline SJ-A-8 & 482 & 959.7 & 12.05 & 0.9597 \\
\hline SJ-A-9 & 473 & 942.1 & 11.82 & 0.9421 \\
\hline SJ-A-10 & 483 & 966.9 & 12.13 & 0.9669 \\
\hline SJ-A-11 & 518 & 1042 & 13.06 & 1.042 \\
\hline SJ-A-12 & 537 & 1072 & 13.44 & 1.072 \\
\hline SJ-A-13 & 554 & 1114 & 13.98 & 1.114 \\
\hline SJ-A-14 & 558 & 1115 & 13.98 & 1.115 \\
\hline
\end{tabular}

\begin{tabular}{|c|c|c|c|c|c|}
\hline Test Number & $\begin{array}{c}\text { Leachant } \\
\text { Volume, } \mathrm{mL}\end{array}$ & $\begin{array}{c}\text { Mass Cs in } \\
\text { Leachant, } \mu \mathrm{g}\end{array}$ & $\begin{array}{c}\text { Mass Cs on } \\
\text { soil, } \mu \mathrm{g}\end{array}$ & $\mu \mathrm{g} \mathrm{Cs} / \mathrm{g}$ soil & $\begin{array}{c}K_{\mathrm{d}}(\mathrm{Cs}) \\
\mathrm{mL} / \mathrm{g}\end{array}$ \\
\hline SJ1-Cs-A-1 & 12.59 & 315.9 & 303.1 & 606.2 & 596.7 \\
\hline SJ1-Cs-A-2 & 12.57 & 315.4 & 302.2 & 604.5 & 578.8 \\
\hline SJ1-Cs-A-3 & 12.58 & 315.6 & 301.5 & 603.0 & 536.2 \\
\hline SJ1-Cs-A-4 & 12.57 & 315.4 & 302.2 & 604.4 & 576.6 \\
\hline SJ1-Cs-A-5 & 12.57 & 315.4 & 302.4 & 604.8 & 586.9 \\
\hline SJ1-Cs-A-6 & 12.57 & 315.4 & 302.1 & 604.3 & 573.8 \\
\hline SJ1-Cs-A-7 & 12.58 & 315.6 & 301.8 & 603.5 & 547.1 \\
\hline SJ1-Cs-A-8 & 12.58 & 315.6 & 303.8 & 607.5 & 644.8 \\
\hline SJ1-Cs-A-9 & 12.57 & 315.4 & 301.7 & 603.4 & 554.3 \\
\hline SJ1-Cs-A-10 & 12.57 & 315.4 & 300.7 & 601.5 & 516.3 \\
\hline SJ2-Cs-A-11 & 12.57 & 315.4 & 302.7 & 605.4 & 600.2 \\
\hline SJ2-Cs-A-12 & 12.58 & 315.6 & 302.3 & 604.5 & 569.0 \\
\hline SJ2-Cs-A-13 & 12.57 & 315.4 & 300.8 & 601.5 & 517.1 \\
\hline SJ2-Cs-A-14 & 12.60 & 316.1 & 302.0 & 604.0 & 538.6 \\
\hline
\end{tabular}

Table 13. (cont.) 


\begin{tabular}{|c|c|c|c|c|c|}
\hline Test Number & $\begin{array}{c}\text { Leachant } \\
\text { Volume, } \mathrm{mL}\end{array}$ & $\begin{array}{c}\text { Mass Sr in } \\
\text { Leachant, } \mu \mathrm{g}\end{array}$ & $\begin{array}{c}\text { Mass Sr on } \\
\text { soil, } \mu \mathrm{g}\end{array}$ & $\mu \mathrm{g} \mathrm{Sr} / \mathrm{g}$ soil & $\begin{array}{c}K_{\mathrm{d}}(\mathrm{Sr}) \\
\mathrm{mL} / \mathrm{g}\end{array}$ \\
\hline SJ1-Sr-A-1 & 12.57 & 102.2 & 90.45 & 180.9 & 193.7 \\
\hline SJ1-Sr-A-2 & 12.58 & 102.3 & 89.99 & 180.0 & 184.4 \\
\hline SJ1-Sr-A-3 & 12.54 & 101.9 & 89.62 & 179.2 & 182.4 \\
\hline SJ1-Sr-A-4 & 12.55 & 102.0 & 89.27 & 178.5 & 175.7 \\
\hline SJ1-Sr-A-5 & 12.54 & 101.9 & 89.89 & 179.8 & 187.0 \\
\hline SJ1-Sr-A-6 & 12.54 & 101.9 & 89.67 & 179.3 & 183.3 \\
\hline SJ1-Sr-A-7 & 12.56 & 102.1 & 89.38 & 178.8 & 176.5 \\
\hline SJ1-Sr-A-8 & 12.55 & 102.0 & 89.98 & 180.0 & 187.5 \\
\hline SJ1-Sr-A-9 & 12.54 & 101.9 & 90.13 & 180.3 & 191.3 \\
\hline SJ1-Sr-A-10 & 12.54 & 101.9 & 89.82 & 179.6 & 185.8 \\
\hline SJ2-Sr-A-11 & 12.54 & 101.9 & 88.88 & 177.8 & 170.7 \\
\hline SJ2-Sr-A-12 & 12.54 & 101.9 & 88.50 & 177.0 & 165.2 \\
\hline SJ2-Sr-A-13 & 12.54 & 101.9 & 87.97 & 175.9 & 157.9 \\
\hline SJ2-Sr-A-14 & 12.54 & 101.9 & 87.97 & 175.9 & 157.9 \\
\hline
\end{tabular}

Note that the tests run for the four shortest durations were conducted with soil from a different bottle of SRM 2709a than the other tests. The dashed lines show the average values of tests run for longer than 10 hours, all of which were conducted with soil from Jar 1. The 6.6-hour tests were also conducted with soil from Jar 1, but not included in the average values indicated by the dashed lines. Soil from Jar 2 was used in tests run for 2 hours or less. The Cs results for the short-term tests with soil from Jar 2 are consistent with the other tests, both with soil from Jar 1 and after longer reaction times. The Sr results for the shortterm tests are consistently higher, although the uncertainty ranges of the data points overlap. The $\mathrm{Sr}$ result of the 6.6-hour test is consistent with the results of longer duration tests, all run with soil from Jar 1. The results suggest that tests with soil from Jar 2 are approaching an equilibrium $\mathrm{Sr}$ concentration that is higher than the equilibrium concentration attained by tests with soil from Jar 1. The result for the 6.6hour test indicates that this is not an effect of reaction time, but a real difference in the properties of the San Joaquin soil in Jars 1 and 2. The difference could result from more $\mathrm{Sr}$ being dissolved from the soil into solution or less Sr being taken up by the soil from solution. Regardless, this indicates that interlaboratory studies should be conducted using well-mixed soil from a single source, which could be a mixture of soil taken from several jars. 


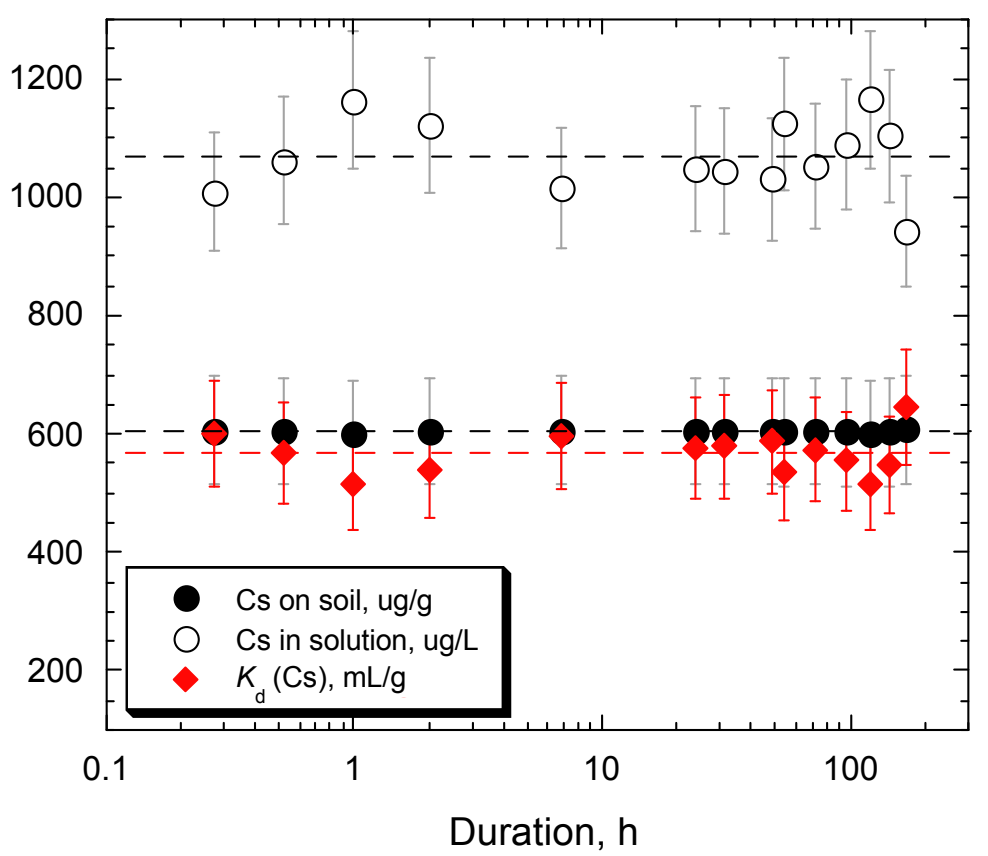

(a)

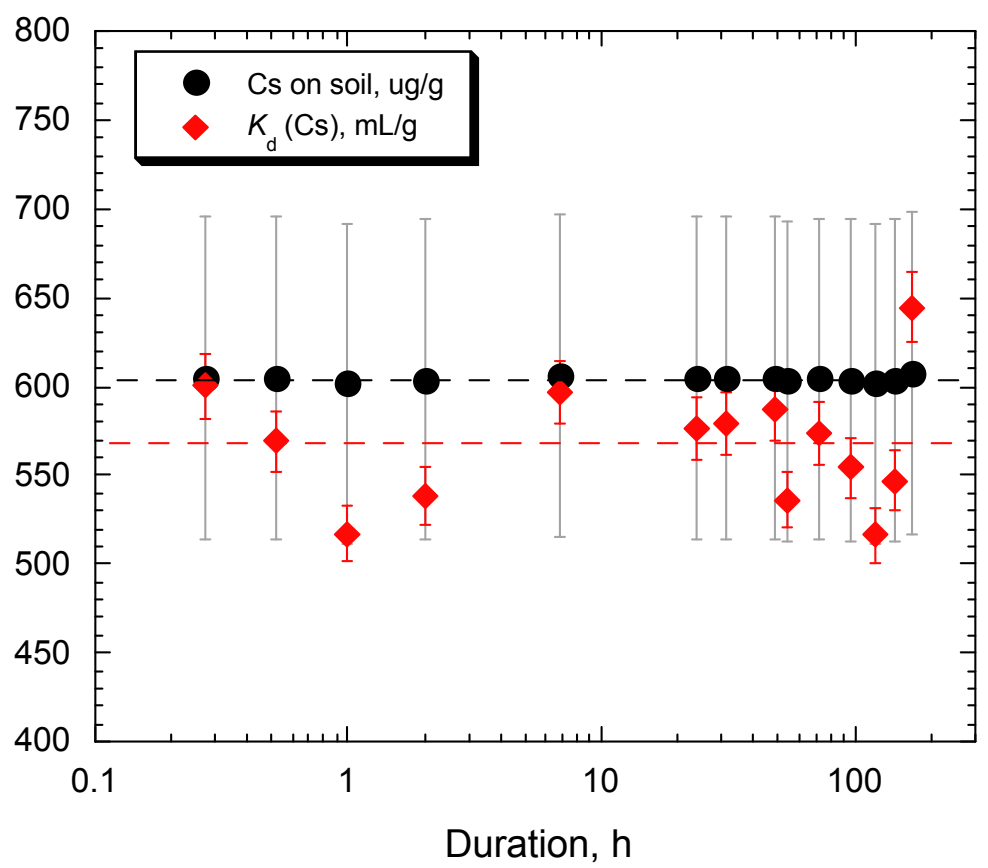

(b)

Figure 7. Results of tests conducted for different duration: (a) concentrations of Cs on soil and in solution, and $K_{\mathrm{d}}$ values vs. test duration and (b) expanded view of Cs on soil and $K_{\mathrm{d}}$ values. Dashed lines show average values for tests conducted for longer than 10 hours. 


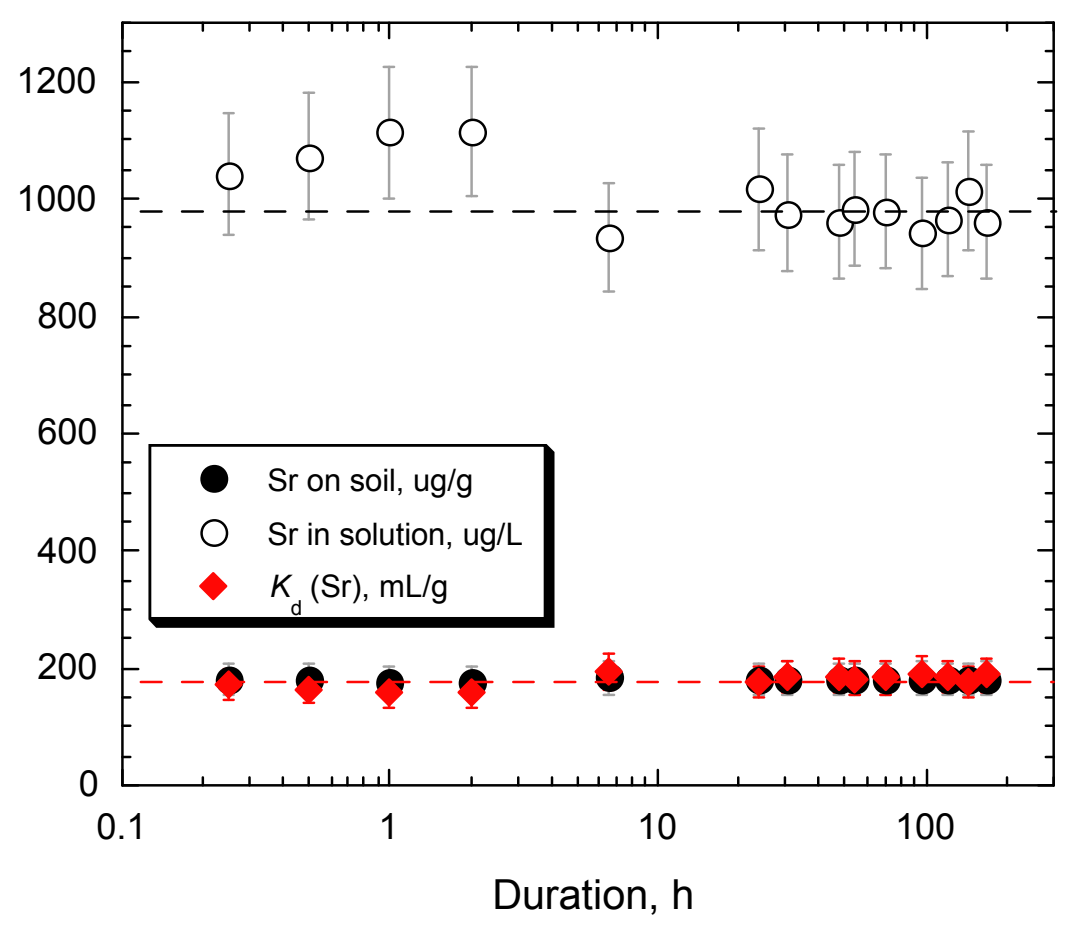

(a)

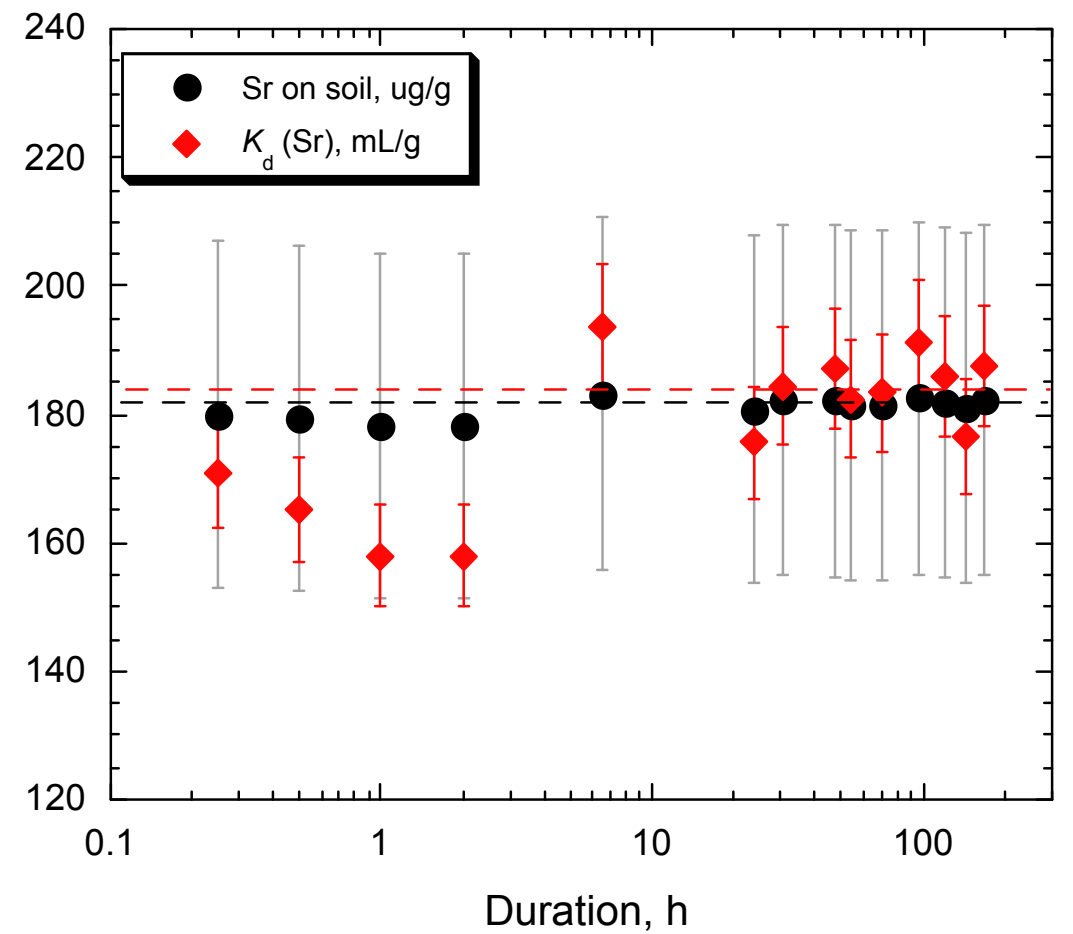

(b)

Figure 8. Results of tests conducted for different duration: (a) concentrations of $\mathrm{Sr}$ on soil and in solution, and $K_{\mathrm{d}}$ values vs. test duration and (b) expanded view of $\mathrm{Sr}$ on soil and $K_{\mathrm{d}}$ values. Dashed lines show average values for tests conducted for longer than 10 hours. 


\subsection{Effects of $\mathrm{pH}$ Tests}

Portions of Cs solution A and $\mathrm{Sr}$ solution A were used to make new solutions with imposed $\mathrm{pH}$ values that were either lower or higher than the nominal $\mathrm{pH} 8.5$ values of the base solutions to assess the effects of $\mathrm{pH}$ on uptake by the soil. Small amounts of either a dilute $\mathrm{HNO}_{3}$ solution or a dilute $\mathrm{NaOH}$ solution were added to adjust the solutions to targeted $\mathrm{pH}$ values of 7.5 (solution A3), 8.0 (solution A4), 8.5 (solution A2), 9.0 (solution A5), or 9.5 (solution A6). These leachants had no buffer capacity, and the solution $\mathrm{pH}$ values drifted during the test. Tests were conducted for 1 and 2 days using soil from Jar 2 . The test data are summarized in Table 14. Tests with A2 solutions were conducted as part of the effects of duration study discussed in Section 3.7, but are included here for completeness. Note that the intended adjustment of the Cs A6 solution to $\mathrm{pH} 9.5$ was not achieved. Note also that all solutions drifted to final $\mathrm{pH}$ values near the leachant blank $\mathrm{pH}$ values of about 8.5. The data for the combination of solutions for analysis are given in Table 15 and the results are given in Table 16. Calculations are discussed in Appendix A.

Table 14. Data for tests conducted with leachants adjusted to different $\mathrm{pH}$ values

\begin{tabular}{|c|c|c|c|c|c|}
\hline Test Number & $\begin{array}{c}\text { Duration, } \\
\mathrm{h}\end{array}$ & $\begin{array}{c}\text { Mass Soil, } \\
\mathrm{g}\end{array}$ & $\begin{array}{c}\text { Mass } \\
\text { Leachant, } \mathrm{g}\end{array}$ & Initial $\mathrm{pH}^{\mathrm{a}}$ & Final $\mathrm{pH}$ \\
\hline SJ2-Cs-A3-1 & 24.00 & 0.50 & 12.51 & 7.54 & 8.44 \\
\hline SJ2-Cs-A3-2 & 47.88 & 0.50 & 12.50 & 7.54 & 8.32 \\
\hline SJ2-Cs-A4-1 & 24.00 & 0.50 & 12.50 & 8.05 & 8.42 \\
\hline SJ2-Cs-A4-2 & 47.88 & 0.50 & 12.50 & 8.05 & 8.38 \\
\hline SJ2-Cs-A2-1 & 24.00 & 0.50 & 12.50 & 8.56 & 8.64 \\
\hline SJ2-Cs-A2-2 & 48.03 & 0.50 & 12.52 & 8.56 & 8.45 \\
\hline SJ2-Cs-A5-1 & 22.08 & 0.50 & 12.50 & 9.12 & 8.43 \\
\hline SJ2-Cs-A5-2 & 47.88 & 0.50 & 12.49 & 9.12 & 8.44 \\
\hline SJ2-Cs-A6-1 & 24.00 & 0.50 & 12.50 & 9.13 & 8.49 \\
\hline SJ2-Cs-A6-2 & 47.88 & 0.50 & 12.50 & 9.13 & 8.46 \\
\hline
\end{tabular}

${ }^{\mathrm{a}}$ Values from Table 3 .

\begin{tabular}{|c|c|c|c|c|c|}
\hline Test Number & $\begin{array}{c}\text { Duration, } \\
\mathrm{h}\end{array}$ & $\begin{array}{c}\text { Mass Soil, } \\
\mathrm{g}\end{array}$ & $\begin{array}{c}\text { Mass } \\
\text { Leachant, } \mathrm{g}\end{array}$ & Initial $\mathrm{pH}^{\mathrm{a}}$ & Final $\mathrm{pH}$ \\
\hline SJ2-Sr-A3-1 & 23.57 & 0.50 & 12.50 & 7.42 & 8.33 \\
\hline SJ2-Sr-A3-2 & 47.45 & 0.50 & 12.51 & 7.42 & 8.28 \\
\hline SJ2-Sr-A4-1 & 23.57 & 0.50 & 12.50 & 8.07 & 8.39 \\
\hline SJ2-Sr-A4-2 & 47.45 & 0.50 & 12.54 & 8.07 & 8.19 \\
\hline SJ2-Sr-A2-1 & 24.00 & 0.50 & 12.50 & 8.56 & 8.53 \\
\hline SJ2-Sr-A2-2 & 48.03 & 0.50 & 12.50 & 8.56 & 8.42 \\
\hline SJ2-Sr-A5-1 & 23.57 & 0.50 & 12.50 & 9.13 & 8.45 \\
\hline SJ2-Sr-A5-2 & 47.45 & 0.50 & 12.53 & 9.13 & 8.30 \\
\hline SJ2-Sr-A6-1 & 23.57 & 0.50 & 12.52 & 9.65 & 8.72 \\
\hline SJ2-Sr-A6-2 & 47.45 & 0.50 & 12.51 & 9.65 & 8.29 \\
\hline
\end{tabular}

${ }^{\mathrm{a}}$ Values from Table 3. 
Table 14. (cont.)

\begin{tabular}{|c|c|c|c|c|}
\hline Test Number & $\begin{array}{c}\text { Solution Bottle, } \\
\mathrm{g}\end{array}$ & $\begin{array}{c}\text { Bottle }+ \text { Cs test } \\
\text { solution, } \mathrm{g}\end{array}$ & $\begin{array}{c}\text { Bottle }+ \text { Cs test solution } \\
+\mathrm{DIW}+\mathrm{HNO}_{3}, \mathrm{~g}\end{array}$ & Cs Dilution Factor \\
\hline SJ2-Cs-A3-1 & 11.15 & 22.44 & 22.53 & 1.008 \\
\hline SJ2-Cs-A3-2 & 11.19 & 22.46 & 22.54 & 1.007 \\
\hline SJ2-Cs-A4-1 & 11.17 & 22.41 & 22.50 & 1.008 \\
\hline SJ2-Cs-A4-2 & 11.25 & 22.37 & 22.44 & 1.006 \\
\hline SJ1-Cs-A2-1 & 11.10 & 22.45 & 22.50 & 1.004 \\
\hline SJ1-Cs-A2-2 & 11.15 & 22.52 & 22.56 & 1.004 \\
\hline SJ2-Cs-A5-1 & 11.20 & 22.43 & 22.51 & 1.007 \\
\hline SJ2-Cs-A5-2 & 11.15 & 22.28 & 22.36 & 1.007 \\
\hline SJ2-Cs-A6-1 & 11.14 & 22.22 & 22.33 & 1.010 \\
\hline SJ2-Cs-A6-2 & 11.22 & 22.35 & 22.50 & 1.013 \\
\hline
\end{tabular}

\begin{tabular}{|c|c|c|c|c|}
\hline Test Number & $\begin{array}{c}\text { Solution Bottle, } \\
\mathrm{g}\end{array}$ & $\begin{array}{c}\text { Bottle }+ \text { Sr test } \\
\text { solution, } \mathrm{g}\end{array}$ & $\begin{array}{c}\text { Bottle }+\mathrm{Sr} \text { solution } \\
+\mathrm{DIW}+\mathrm{HNO}_{3}, \mathrm{~g}\end{array}$ & Sr Dilution Factor \\
\hline SJ2-Sr-A3-1 & 11.18 & 22.35 & 22.41 & 1.005 \\
\hline SJ2-Sr-A3-2 & 11.14 & 22.23 & 22.28 & 1.005 \\
\hline SJ2-Sr-A4-1 & 11.17 & 22.33 & 22.42 & 1.008 \\
\hline SJ2-Sr-A4-2 & 11.21 & 22.41 & 22.55 & 1.013 \\
\hline SJ2-Sr-A2-1 & 11.10 & 22.45 & 22.50 & 1.004 \\
\hline SJ2-Sr-A2-2 & 11.16 & 22.38 & 22.44 & 1.005 \\
\hline SJ2-Sr-A5-1 & 11.18 & 22.27 & 22.34 & 1.006 \\
\hline SJ2-Sr-A5-2 & 11.22 & 22.41 & 22.53 & 1.011 \\
\hline SJ2-Sr-A6-1 & 11.19 & 22.45 & 22.56 & 1.010 \\
\hline SJ2-Sr-A6-2 & 11.15 & 22.27 & 22.37 & 1.009 \\
\hline
\end{tabular}

Table 15. Combination of solutions for tests conducted with leachants adjusted to different $\mathrm{pH}$ values

\begin{tabular}{|c|c|c|}
\hline $\begin{array}{c}\text { Solution } \\
\text { Number }\end{array}$ & Solution 1 & Solution 2 \\
\hline SJ-A-1 & SJ2-Cs-A3-1 & SJ2-Sr-A3-1 \\
\hline SJ-A-2 & SJ2-Cs-A3-2 & SJ2-Sr-A3-2 \\
\hline SJ-A-3 & SJ2-Cs-A4-1 & SJ2-Sr-A4-1 \\
\hline SJ-A-4 & SJ2-Cs-A4-2 & SJ2-Sr-A4-2 \\
\hline SJ-A-5 & SJ2-Cs-A5-1 & SJ2-Sr-A5-1 \\
\hline SJ-A-6 & SJ2-Cs-A5-2 & SJ2-Sr-A5-2 \\
\hline SJ-A-7 & SJ2-Cs-A6-1 & SJ2-Sr-A6-1 \\
\hline SJ-A-8 & SJ2-Cs-A6-2 & SJ2-Sr-A6-2 \\
\hline
\end{tabular}

\begin{tabular}{|c|c|c|c|c|c|}
\hline Test Number & $\begin{array}{c}\text { Mixed Solution } \\
\text { Bottle, } \mathrm{g}\end{array}$ & $\begin{array}{c}\text { Bottle }+ \text { Cs test } \\
\text { solution, } \mathrm{g}\end{array}$ & $\begin{array}{c}\text { Bottle }+ \text { Cs }+\mathrm{Sr} \\
\text { test solution, } \mathrm{g}\end{array}$ & $\begin{array}{c}\text { Cs Dilution } \\
\text { Factor }\end{array}$ & $\begin{array}{c}\text { Sr Dilution } \\
\text { Factor }\end{array}$ \\
\hline SJ-A-1 & 11.19 & 22.43 & 33.48 & 1.9831 & 2.017 \\
\hline SJ-A-2 & 11.16 & 22.38 & 33.37 & 1.9795 & 2.021 \\
\hline SJ-A-3 & 11.06 & 22.23 & 33.29 & 1.9902 & 2.010 \\
\hline SJ-A-4 & 11.20 & 22.20 & 33.42 & 2.0200 & 1.980 \\
\hline SJ-A-5 & 11.17 & 22.35 & 33.35 & 1.9839 & 2.016 \\
\hline SJ-A-6 & 11.16 & 22.17 & 33.33 & 2.0136 & 1.987 \\
\hline SJ-A-7 & 11.13 & 22.15 & 33.32 & 2.0136 & 1.987 \\
\hline SJ-A-8 & 11.21 & 22.34 & 33.44 & 1.9973 & 2.003 \\
\hline
\end{tabular}


Table 16. Solution results for tests conducted with leachants adjusted to different $\mathrm{pH}$ values

\begin{tabular}{|c|c|c|c|c|}
\hline Test Number & $\begin{array}{c}\text { Measured Cs, } \\
\mu \mathrm{g} / \mathrm{L}\end{array}$ & $\begin{array}{c}\text { Dil.-corrected Cs, } \\
\mu \mathrm{g} / \mathrm{L}\end{array}$ & $\begin{array}{c}\text { Cs in test solution, } \\
\mu \mathrm{g}\end{array}$ & $\begin{array}{c}\text { Cs in test solution, } \\
\mu \mathrm{g} / \mathrm{mL}\end{array}$ \\
\hline SJ2-Cs-A3-1 & 593 & 1176 & 14.79 & 1.176 \\
\hline SJ2-Cs-A3-2 & 641 & 1269 & 15.95 & 1.269 \\
\hline SJ2-Cs-A4-1 & 596 & 1186 & 14.91 & 1.186 \\
\hline SJ2-Cs-A4-2 & 573 & 1157 & 14.55 & 1.157 \\
\hline SJ-A2-1 & 552 & 1101 & 13.84 & 1.101 \\
\hline SJ-A2-2 & 573 & 1139 & 14.34 & 1.139 \\
\hline SJ2-Cs-A5-1 & 515 & 1022 & 12.84 & 1.022 \\
\hline SJ2-Cs-A5-2 & 527 & 1061 & 13.33 & 1.061 \\
\hline SJ2-Cs-A6-1 & 574 & 1156 & 14.53 & 1.156 \\
\hline SJ2-Cs-A6-2 & 569 & 1136 & 14.28 & 1.136 \\
\hline
\end{tabular}

\begin{tabular}{|c|c|c|c|c|}
\hline Test Number & $\begin{array}{c}\text { Measured Sr, } \\
\mu \mathrm{g} / \mathrm{L}\end{array}$ & $\begin{array}{c}\text { Dil.-corrected Sr, } \\
\mu \mathrm{g} / \mathrm{L}\end{array}$ & $\begin{array}{c}\text { Sr in test solution, } \\
\mu \mathrm{g}\end{array}$ & $\begin{array}{c}\text { Sr in test solution, } \\
\mu \mathrm{g} / \mathrm{mL}\end{array}$ \\
\hline SJ2-Sr-A3-1 & 715 & 1442 & 18.09 & 1.44 \\
\hline SJ2-Sr-A3-2 & 680 & 1374 & 17.25 & 1.37 \\
\hline SJ2-Sr-A4-1 & 637 & 1280 & 16.06 & 1.28 \\
\hline SJ2-Sr-A4-2 & 616 & 1220 & 15.35 & 1.22 \\
\hline SJ-A2-1 & 528 & 1059 & 13.28 & 1.059 \\
\hline SJ-A2-2 & 528 & 1062 & 13.32 & 1.062 \\
\hline SJ2-Sr-A5-1 & 258 & 520 & 6.53 & 0.520 \\
\hline SJ2-Sr-A5-2 & 290 & 576 & 7.24 & 0.576 \\
\hline SJ2-Sr-A6-1 & 82.4 & 164 & 2.06 & 0.164 \\
\hline SJ2-Sr-A6-2 & 86.5 & 173 & 2.17 & 0.173 \\
\hline
\end{tabular}

\begin{tabular}{|c|c|c|c|c|c|}
\hline Test Number & $\begin{array}{c}\text { Leachant } \\
\text { Volume, } \mathrm{mL}\end{array}$ & $\begin{array}{c}\text { Mass Cs in } \\
\text { Leachant, } \mu \mathrm{g}\end{array}$ & $\begin{array}{c}\text { Mass Cs on } \\
\text { soil, } \mu \mathrm{g}\end{array}$ & $\mu \mathrm{g}$ Cs/g soil & $\begin{array}{c}K_{\mathrm{d}}(\mathrm{Cs}) \\
\mathrm{mL} / \mathrm{g}\end{array}$ \\
\hline SJ2-Cs-A3-1 & 12.58 & 315.62 & 301 & 602 & 511.6 \\
\hline SJ2-Cs-A3-2 & 12.57 & 315.37 & 299 & 599 & 472.0 \\
\hline SJ2-Cs-A4-1 & 12.57 & 315.37 & 300 & 601 & 506.6 \\
\hline SJ2-Cs-A4-2 & 12.57 & 315.37 & 301 & 602 & 519.8 \\
\hline SJ1-Cs-A2-1 & 12.57 & 308.63 & 302 & 603 & 547.7 \\
\hline SJ1-Cs-A2-2 & 12.59 & 309.13 & 301 & 602 & 528.4 \\
\hline SJ2-Cs-A5-1 & 12.57 & 315.37 & 302 & 605 & 592.2 \\
\hline SJ2-Cs-A5-2 & 12.56 & 315.12 & 302 & 604 & 568.8 \\
\hline SJ2-Cs-A6-1 & 12.57 & 315.37 & 301 & 602 & 520.6 \\
\hline SJ2-Cs-A6-2 & 12.57 & 315.37 & 301 & 602 & 529.9 \\
\hline
\end{tabular}

\begin{tabular}{|c|c|c|c|c|c|}
\hline Test Number & $\begin{array}{c}\text { Leachant } \\
\text { Volume, } \mathrm{mL}\end{array}$ & $\begin{array}{c}\text { Mass Sr in } \\
\text { Leachant }{ }^{\mathrm{a}}, \mu \mathrm{g}\end{array}$ & $\begin{array}{c}\text { Mass Sr on } \\
\text { soil, } \mu \mathrm{g}\end{array}$ & $\mu \mathrm{g}$ Sr/g soil & $\begin{array}{c}K_{\mathrm{d}}(\mathrm{Sr}) \\
\mathrm{mL} / \mathrm{g}\end{array}$ \\
\hline SJ2-Sr-A3-1 & 12.54 & 101.9 & 83.9 & 168 & 116.3 \\
\hline SJ2-Sr-A3-2 & 12.55 & 102.0 & 84.8 & 170 & 123.4 \\
\hline SJ2-Sr-A4-1 & 12.54 & 101.9 & 85.9 & 172 & 134.2 \\
\hline SJ2-Sr-A4-2 & 12.58 & 102.3 & 86.9 & 174 & 142.5 \\
\hline SJ2-Sr-A2-1 & 12.54 & 102.1 & 88.8 & 178 & 167.7 \\
\hline SJ2-Sr-A2-2 & 12.54 & 102.0 & 88.7 & 177 & 167.0 \\
\hline SJ2-Sr-A5-1 & 12.54 & 101.9 & 95.4 & 191 & 366.8 \\
\hline SJ2-Sr-A5-2 & 12.57 & 102.2 & 94.9 & 190 & 329.6 \\
\hline SJ2-Sr-A6-1 & 12.56 & 102.1 & 100 & 200 & 1222 \\
\hline SJ2-Sr-A6-2 & 12.55 & 102.0 & 99.9 & 200 & 1153 \\
\hline
\end{tabular}

${ }^{\mathrm{a}} \mathrm{Calculated}$ using concentration in $\mathrm{Sr}$ A solution to be consistent with other tests. 
Figures $9 \mathrm{a}$ and $9 \mathrm{~b}$ show the masses of $\mathrm{Cs}$ and $\mathrm{Sr}$ calculated to be in the leachant solution and in the test solutions and on the soil after reacting for 1 or 2 days. Uncertainty bars are drawn at $10 \%$ for the masses in the leachants and test solutions, and at $15 \%$ for the masses on the soil. The results for the 1- and 2-day tests overlap at all $\mathrm{pH}$ values for both $\mathrm{Cs}$ and $\mathrm{Sr}$. As determined from the Cs concentrations in the test solutions, almost all of the Cs present in the leachant was taken up by the soil within 1 day at all $\mathrm{pH}$ values. The uptake of $\mathrm{Sr}$ showed a dependence on the $\mathrm{pH}$, where more $\mathrm{Sr}$ was taken up from the solutions with higher imposed $\mathrm{pH}$ values.

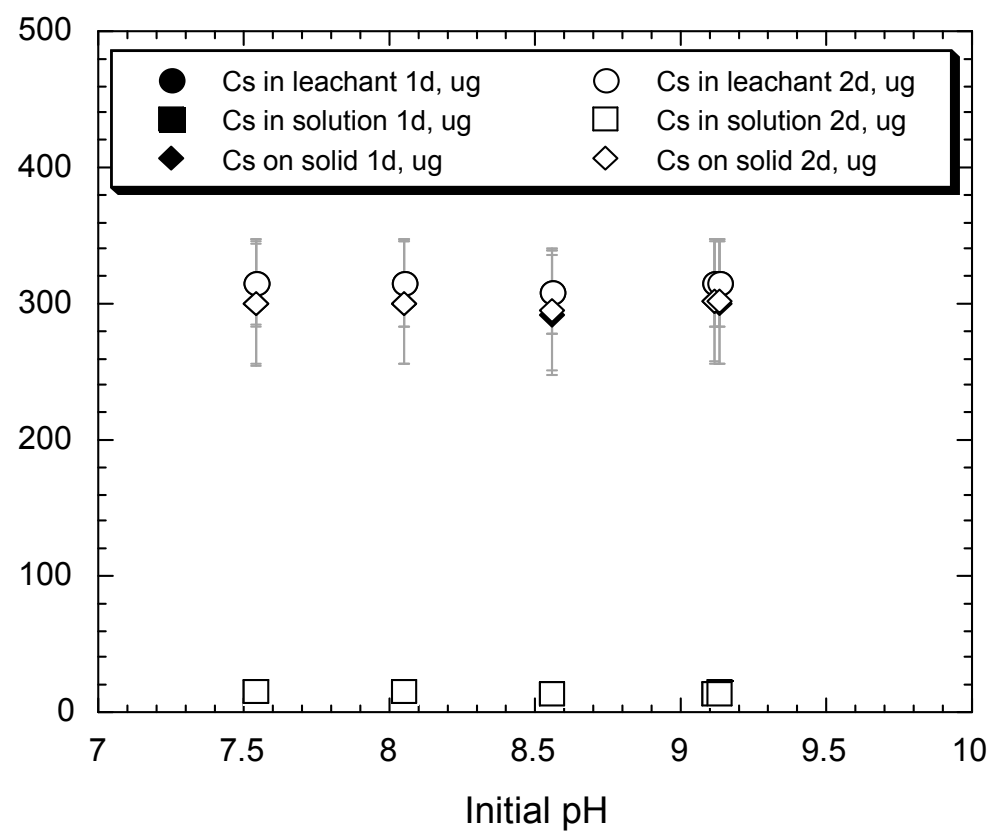

(a)

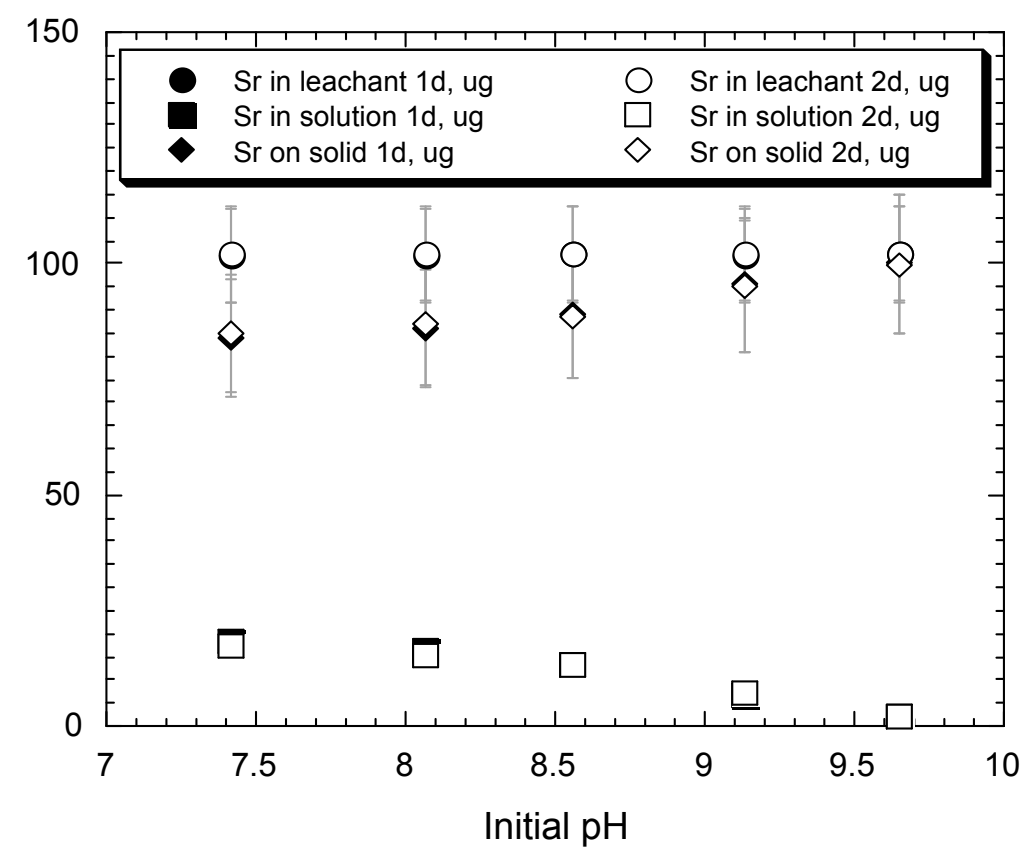

(b)

Figure 9. Results of tests conducted with different imposed $\mathrm{pH}$ values: (a) Cs masses in leachant, in test solution, and on soil vs. initial $\mathrm{pH}$ and (b) Sr masses in leachant, in test solution, and on soil vs. initial $\mathrm{pH}$. 
Figures 10a and 10b show the distributions on per mass and per volume bases, and the calculated $K_{\mathrm{d}}$ values. These ratios emphasize the small differences in the distributions. The result of tests with Cs solution A2 and $\mathrm{Sr}$ solution A2 conducted for 1 and 2 days as part of the series of tests to study the effects of reaction time are included in the plots at about $\mathrm{pH}$ 8.3. Note that these tests were conducted with soil from Jar 1 whereas the tests conducted to study the effects of $\mathrm{pH}$ were conducted with soil from Jar 2. The distribution coefficient of $\mathrm{Cs}$ is insensitive to the imposed $\mathrm{pH}$, but the distribution coefficient of $\mathrm{Sr}$ increases significantly as the imposed $\mathrm{pH}$ is increased, despite the fact the $\mathrm{pH}$ values drifted to about $\mathrm{pH}$ 8.5. This suggests the uptake of Sr is not rapidly reversible, but other tests are needed to verify that.

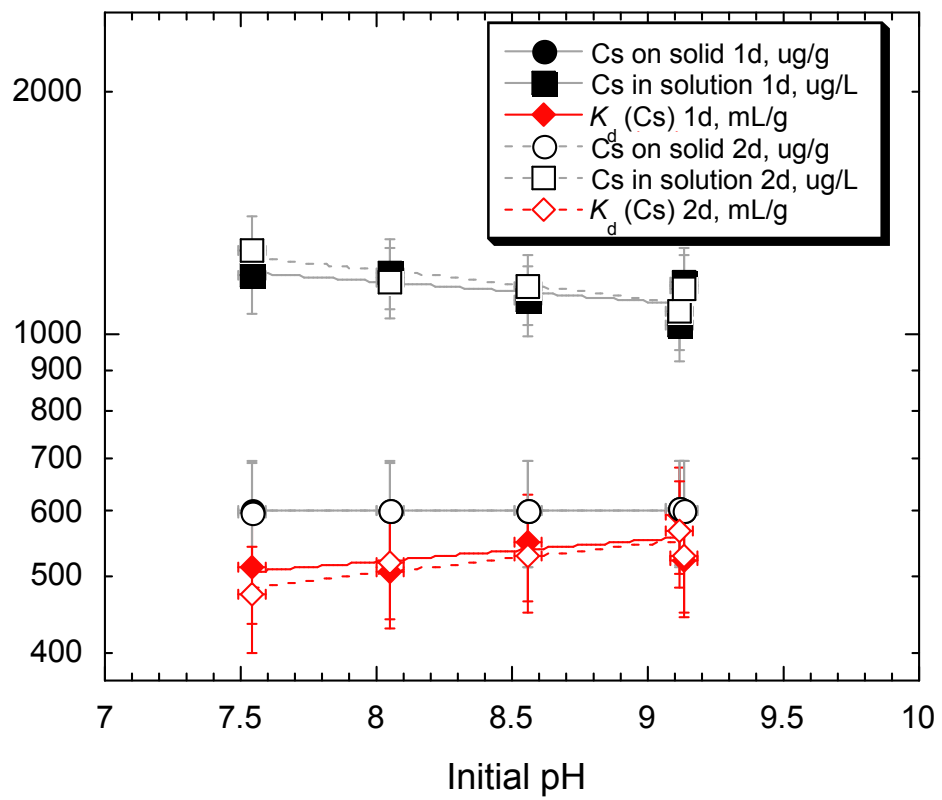

(a)

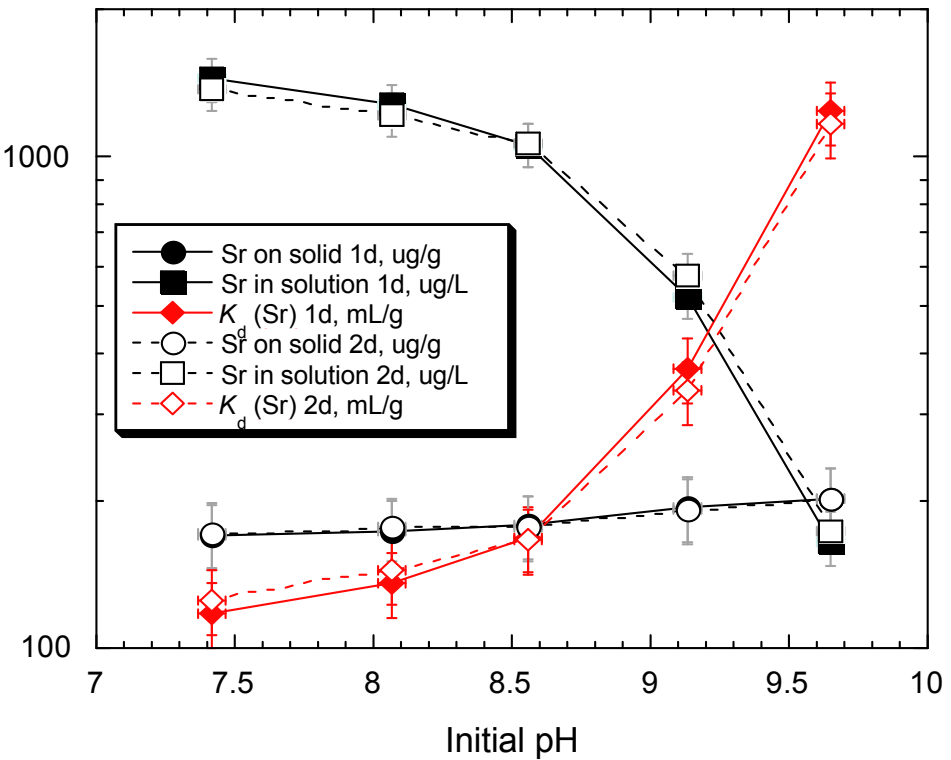

(b)

Figure 10. Results of tests conducted with different imposed $\mathrm{pH}$ values: (a) concentrations of $\mathrm{Cs}$ on the soil and in solution, and $K_{\mathrm{d}}$ values, and (b) concentrations of $\mathrm{Sr}$ on the soil and in solution, and $K_{\mathrm{d}}$ values. 


\subsection{Effects of Concentration Tests}

Tests were conducted using six Cs concentrations and six Sr concentrations to evaluate the effects of contaminant concentration on the values of $K_{d}$ and the evaluation of analytical sorption isotherms. Tests were run for 1,2, and 3 days with each concentration to detect possible kinetic effects. The test data are provided in Table 17. Data for the combination of solutions for analysis are summarized in Table 18 and the results are given in Table 19. Calculations are discussed in Appendix B. Though it was not the intent of this work to quantify the sorption behaviors of $\mathrm{Cs}$ and $\mathrm{Sr}$, preliminary applications of linear, Freundlich, and Langmuir isotherms are discussed to show the usefulness of the test results.

Table 17. Data for tests run with various Cs solution and Sr solution concentrations

\begin{tabular}{|c|c|c|c|c|c|}
\hline Test Number & $\begin{array}{c}\text { Duration, } \\
\mathrm{h}\end{array}$ & $\begin{array}{c}\text { Mass Soil, } \\
\mathrm{g}\end{array}$ & $\begin{array}{c}\text { Mass } \\
\text { Leachant, } \mathrm{g}\end{array}$ & $\begin{array}{c}\text { Soil/Leachant } \\
\text { mass ratio }\end{array}$ & Final $\mathrm{pH}$ \\
\hline SJ1-Cs-A2-0 & 74.87 & - & 12.51 & - & 8.56 \\
\hline SJ1-Cs-A2-1 & 24.00 & 0.50 & 12.50 & 0.0400 & 8.64 \\
\hline SJ1-Cs-A2-2 & 48.03 & 0.50 & 12.52 & 0.0399 & 8.45 \\
\hline SJ1-Cs-A2-3 & 74.87 & 0.50 & 12.50 & 0.0400 & 8.43 \\
\hline SJ1-Cs-B-0 & 71.63 & - & 12.50 & - & 8.53 \\
\hline SJ1-Cs-B-3 & 24.00 & 0.50 & 12.50 & 0.0400 & 8.44 \\
\hline SJ1-Cs-B-4 & 48.03 & 0.50 & 12.51 & 0.0400 & 8.41 \\
\hline SJ1-Cs-B-5 & 78.60 & 0.50 & 12.50 & 0.0400 & 8.37 \\
\hline SJ1-Cs-C-0 & 71.63 & - & 12.51 & - & 8.40 \\
\hline SJ1-Cs-C-3 & 24.00 & 0.50 & 12.50 & 0.0400 & 8.45 \\
\hline SJ1-Cs-C-4 & 48.03 & 0.50 & 12.50 & 0.0400 & 8.46 \\
\hline SJ1-Cs-C-5 & 78.60 & 0.50 & 12.50 & 0.0400 & 8.40 \\
\hline SJ1-Cs-D-0 & 71.63 & - & 12.50 & - & 8.47 \\
\hline SJ1-Cs-D-3 & 24.00 & 0.50 & 12.50 & 0.0400 & 8.44 \\
\hline SJ1-Cs-D-4 & 48.03 & 0.50 & 12.50 & 0.0400 & 8.44 \\
\hline SJ1-Cs-D-5 & 78.60 & 0.50 & 12.53 & 0.0399 & 8.39 \\
\hline SJ1-Cs-E-0 & 71.63 & - & 12.50 & - & 8.44 \\
\hline SJ1-Cs-E-3 & 24.00 & 0.50 & 12.51 & 0.0400 & 8.45 \\
\hline SJ1-Cs-E-4 & 48.03 & 0.50 & 12.50 & 0.0400 & 8.37 \\
\hline SJ1-Cs-E-5 & 78.60 & 0.50 & 12.51 & 0.0400 & 8.41 \\
\hline SJ1-Cs-F-0 & 71.63 & - & 12.50 & - & 8.48 \\
\hline SJ1-Cs-F-4 & 24.00 & 0.50 & 12.53 & 0.0399 & 8.44 \\
\hline SJ1-Cs-F-5 & 78.60 & 0.50 & 12.50 & 0.0400 & 8.48 \\
\hline SJ1-Cs-F-6 & 48.03 & 0.50 & 12.50 & 0.0400 & 8.44 \\
\hline
\end{tabular}

\begin{tabular}{|c|c|c|c|c|c|}
\hline Test Number & $\begin{array}{c}\text { Duration, } \\
\mathrm{h}\end{array}$ & $\begin{array}{c}\text { Mass Soil, } \\
\mathrm{g}\end{array}$ & $\begin{array}{c}\text { Mass } \\
\text { Leachant, } \mathrm{g}\end{array}$ & $\begin{array}{c}\text { Soil/Leachant } \\
\text { mass ratio }\end{array}$ & Final $\mathrm{pH}$ \\
\hline SJ2-Sr-A2-0 & 74.87 & - & 12.51 & - & 8.56 \\
\hline SJ2-Sr-A2-1 & 24.00 & 0.50 & 12.50 & 0.0400 & 8.53 \\
\hline SJ2-Sr-A2-2 & 48.03 & 0.50 & 12.50 & 0.0400 & 8.42 \\
\hline SJ2-Sr-A2-3 & 74.87 & 0.50 & 12.51 & 0.0400 & 8.43 \\
\hline SJ1-Sr-B-0 & 78.93 & - & 12.51 & - & 8.10 \\
\hline SJ1-Sr-B-3 & 24.00 & 0.50 & 12.50 & 0.0400 & 8.24 \\
\hline SJ1-Sr-B-4 & 48.03 & 0.50 & 12.50 & 0.0400 & 8.28 \\
\hline SJ1-Sr-B-5 & 71.63 & 0.50 & 12.50 & 0.0400 & 8.23 \\
\hline SJ1-Sr-C-0 & 78.93 & - & 12.50 & - & 8.52 \\
\hline
\end{tabular}


Table 17. (cont.)

\begin{tabular}{|c|c|c|c|c|c|}
\hline Test Number & $\begin{array}{c}\text { Duration, } \\
\mathrm{h}\end{array}$ & $\begin{array}{c}\text { Mass Soil, } \\
\mathrm{g}\end{array}$ & $\begin{array}{c}\text { Mass } \\
\text { Leachant, } \mathrm{g}\end{array}$ & $\begin{array}{c}\text { Soil/Leachant } \\
\text { mass ratio }\end{array}$ & Final $\mathrm{pH}$ \\
\hline SJ1-Sr-C-3 & 24.00 & 0.50 & 12.50 & 0.0400 & 8.40 \\
\hline SJ1-Sr-C-4 & 47.97 & 0.50 & 12.51 & 0.0400 & 8.42 \\
\hline SJ1-Sr-C-5 & 71.63 & 0.50 & 12.51 & 0.0400 & 8.43 \\
\hline SJ1-Sr-D-0 & 78.93 & - & 12.50 & - & 8.52 \\
\hline SJ1-Sr-D-3 & 24.00 & 0.50 & 12.51 & 0.0400 & 8.45 \\
\hline SJ1-Sr-D-4 & 47.97 & 0.40 & 10.01 & 0.0400 & 8.47 \\
\hline SJ1-Sr-D-5 & 71.63 & 0.50 & 12.50 & 0.0400 & 8.47 \\
\hline SJ1-Sr-E-0 & 78.93 & - & 12.51 & - & 8.50 \\
\hline SJ1-Sr-E-3 & 24.00 & 0.50 & 12.50 & 0.0400 & 8.46 \\
\hline SJ1-Sr-E-4 & 47.97 & 0.50 & 12.53 & 0.0399 & 8.42 \\
\hline SJ1-Sr-E-5 & 71.63 & 0.50 & 12.52 & 0.0399 & 8.47 \\
\hline SJ1-Sr-F-0 & 78.93 & - & 12.50 & - & 8.50 \\
\hline SJ1-Sr-F-3 & 24.00 & 0.50 & 12.50 & 0.0400 & 8.43 \\
\hline SJ1-Sr-F-4 & 47.97 & 0.50 & 12.51 & 0.0400 & 8.46 \\
\hline SJ1-Sr-F-5 & 71.63 & 0.50 & 12.51 & 0.0400 & 8.47 \\
\hline SJ1-Sr-F-0 & 47.88 & - & 12.50 & 0.0000 & 8.62 \\
\hline
\end{tabular}

${ }^{a}$ Repeat of blank test SJ1-Sr-F0.

\begin{tabular}{|c|c|c|c|c|}
\hline Test Number & $\begin{array}{c}\text { Solution Bottle, } \\
\mathrm{g}\end{array}$ & $\begin{array}{c}\text { Bottle }+ \text { Cs test } \\
\text { solution, } \mathrm{g}\end{array}$ & $\begin{array}{c}\text { Bottle + Cs test solution } \\
+\mathrm{DIW}+\mathrm{HNO}_{3}, \mathrm{~g}\end{array}$ & Dilution Factor \\
\hline SJ1-Cs-A2-0 & 11.16 & 22.97 & 23.03 & 1.005 \\
\hline SJ1-Cs-A2-1 & 11.10 & 22.45 & 22.50 & 1.004 \\
\hline SJ1-Cs-A2-2 & 11.15 & 22.52 & 22.56 & 1.004 \\
\hline SJ1-Cs-A2-3 & 11.18 & 22.30 & 22.36 & 1.005 \\
\hline SJ1-Cs-B-0 & 11.17 & 22.82 & 22.88 & 1.005 \\
\hline SJ1-Cs-B-3 & 11.14 & 22.56 & 22.61 & 1.004 \\
\hline SJ1-Cs-B-4 & 11.16 & 21.96 & 22.03 & 1.006 \\
\hline SJ1-Cs-B-5 & 11.19 & 22.24 & 22.28 & 1.004 \\
\hline SJ1-Cs-C-0 & 11.14 & 23.03 & 23.11 & 1.007 \\
\hline SJ1-Cs-C-3 & 11.14 & 22.53 & 22.57 & 1.004 \\
\hline SJ1-Cs-C-4 & 11.21 & 22.46 & 22.53 & 1.006 \\
\hline SJ1-Cs-C-5 & 11.11 & 22.25 & 22.28 & 1.003 \\
\hline SJ1-Cs-D-0 & 11.16 & 22.90 & 22.93 & 1.003 \\
\hline SJ1-Cs-D-3 & 11.18 & 22.48 & 22.51 & 1.003 \\
\hline SJ1-Cs-D-4 & 11.14 & 22.36 & 22.42 & 1.005 \\
\hline SJ1-Cs-D-5 & 11.13 & 22.29 & 22.32 & 1.003 \\
\hline SJ1-Cs-E-0 & 11.15 & 22.89 & 22.93 & 1.003 \\
\hline SJ1-Cs-E-3 & 11.21 & 22.62 & 22.66 & 1.004 \\
\hline SJ1-Cs-E-4 & 11.17 & 22.36 & 22.42 & 1.005 \\
\hline SJ1-Cs-E-5 & 11.13 & 22.33 & 22.39 & 1.005 \\
\hline SJ1-Cs-F-0 & 11.19 & 22.94 & 23.00 & 1.005 \\
\hline SJ1-Cs-F-4 & 11.12 & 22.45 & 22.50 & 1.004 \\
\hline SJ1-Cs-F-5 & 11.11 & 22.37 & 22.42 & 1.004 \\
\hline SJ1-Cs-F-6 & 11.12 & 22.41 & 22.49 & 1.007 \\
\hline
\end{tabular}


Table 17. (cont.)

\begin{tabular}{|c|c|c|c|c|}
\hline Test Number & $\begin{array}{c}\text { Solution Bottle, } \\
\mathrm{g}\end{array}$ & $\begin{array}{c}\text { Bottle }+ \text { Sr test } \\
\text { solution, },\end{array}$ & $\begin{array}{c}\text { Bottle }+ \text { Sr test solution } \\
+\mathrm{DIW}+\mathrm{HNO}_{3}, \mathrm{~g}\end{array}$ & Dilution Factor \\
\hline SJ2-Sr-A2-0 & 11.16 & 22.97 & 23.03 & 1.005 \\
\hline SJ2-Sr-A2-1 & 11.10 & 22.45 & 22.50 & 1.004 \\
\hline SJ2-Sr-A2-2 & 11.16 & 22.38 & 22.44 & 1.005 \\
\hline SJ2-Sr-A2-3 & 11.18 & 22.30 & 22.36 & 1.005 \\
\hline SJ1-Sr-B-0 & 11.10 & 22.73 & 22.78 & 1.004 \\
\hline SJ1-Sr-B-3 & 11.17 & 22.46 & 22.52 & 1.005 \\
\hline SJ1-Sr-B-4 & 11.18 & 22.28 & 22.34 & 1.005 \\
\hline SJ1-Sr-B-5 & 11.18 & 22.43 & 22.47 & 1.004 \\
\hline SJ1-Sr-C-0 & 11.21 & 22.87 & 22.94 & 1.006 \\
\hline SJ1-Sr-C-3 & 11.14 & 22.46 & 22.49 & 1.003 \\
\hline SJ1-Sr-C-4 & 11.10 & 22.25 & 22.32 & 1.006 \\
\hline SJ1-Sr-C-5 & 11.15 & 22.27 & 22.32 & 1.004 \\
\hline SJ1-Sr-D-0 & 11.19 & 22.87 & 22.94 & 1.006 \\
\hline SJ1-Sr-D-3 & 11.13 & 22.37 & 22.41 & 1.004 \\
\hline SJ1-Sr-D-4 & 11.15 & 20.08 & 20.17 & 1.010 \\
\hline SJ1-Sr-D-5 & 11.15 & 22.27 & 22.31 & 1.004 \\
\hline SJ1-Sr-E-0 & 11.17 & 22.91 & 22.94 & 1.003 \\
\hline SJ1-Sr-E-3 & 11.13 & 22.47 & 22.50 & 1.003 \\
\hline SJ1-Sr-E-4 & 11.19 & 22.41 & 22.49 & 1.007 \\
\hline SJ1-Sr-E-5 & 11.04 & 22.32 & 22.36 & 1.004 \\
\hline SJ1-Sr-F-0 & 11.24 & 22.98 & 23.02 & 1.003 \\
\hline SJ1-Sr-F-3 & 11.11 & 22.47 & 22.53 & 1.005 \\
\hline SJ1-Sr-F-4 & 11.16 & 22.41 & 22.48 & 1.006 \\
\hline SJ1-Sr-F-5 & 11.12 & 21.94 & 21.99 & 1.005 \\
\hline SJ1-Sr-F-0 & 11.11 & 22.82 & 22.92 & 1.009 \\
\hline
\end{tabular}

${ }^{\mathrm{a}}$ Repeat of blank test SJ1-Sr-F0.

Table 18. Combination of test solutions for analysis

\begin{tabular}{|c|c|c|c|c|c|}
\hline $\begin{array}{c}\text { Solution } \\
\text { Number }\end{array}$ & Solution 1 & Solution 2 & $\begin{array}{c}\text { Solution } \\
\text { Number }\end{array}$ & Solution 1 & Solution 2 \\
\hline SJ-A2-0 & SJ1-Cs-A2-0 & SJ2-Sr-A2-0 & SJ-D-0 & SJ1-Cs-D-0 & SJ1-Sr-D-0 \\
\hline SJ-A2-1 & SJ1-Cs-A2-1 & SJ2-Sr-A2-1 & SJ-D-3 & SJ1-Cs-D-3 & SJ1-Sr-D-3 \\
\hline SJ-A2-2 & SJ1-Cs-A2-2 & SJ2-Sr-A2-2 & SJ-D-4 & SJ1-Cs-D-4 & SJ1-Sr-D-4 \\
\hline SJ-A2-3 & SJ1-Cs-A2-3 & SJ2-Sr-A2-3 & SJ-D-5 & SJ1-Cs-D-5 & SJ1-Sr-D-5 \\
\hline SJ-B-0 & SJ1-Cs-B-0 & SJ1-Sr-B-0 & SJ-E-0 & SJ1-Cs-E-0 & SJ1-Sr-E-0 \\
\hline SJ-B-3 & SJ1-Cs-B-3 & SJ1-Sr-B-3 & SJ-E-3 & SJ1-Cs-E-3 & SJ1-Sr-E-3 \\
\hline SJ-B-4 & SJ1-Cs-B-4 & SJ1-Sr-B-4 & SJ-E-4 & SJ1-Cs-E-4 & SJ1-Sr-E-4 \\
\hline SJ-B-5 & SJ1-Cs-B-5 & SJ1-Sr-B-5 & SJ-E-5 & SJ1-Cs-E-5 & SJ1-Sr-E-5 \\
\hline SJ-C-0 & SJ1-Cs-C-0 & SJ1-Sr-C-0 & SJ-F-0 & SJ1-Cs-F-0 & SJ1-Sr-F-0 \\
\hline SJ-C-3 & SJ1-Cs-C-3 & SJ1-Sr-C-3 & SJ-F-3 & SJ1-Cs-F-4 & SJ1-Sr-F-3 \\
\hline SJ-C-4 & SJ1-Cs-C-4 & SJ1-Sr-C-4 & SJ-F-4 & SJ1-Cs-F-5 & SJ1-Sr-F-4 \\
\hline SJ-C-5 & SJ1-Cs-C-5 & SJ1-Sr-C-5 & SJ-F-5 & SJ1-Cs-F-6 & SJ1-Sr-F-5 \\
\hline SJ-A2-0 & 11.12 & 22.98 & 34.80 & 1.997 & 2.003 \\
\hline SJ-A2-1 & 11.12 & 22.41 & 33.64 & 1.995 & 2.005 \\
\hline
\end{tabular}


Table 18. (cont.)

\begin{tabular}{|c|c|c|c|c|c|}
\hline $\begin{array}{c}\text { Solution } \\
\text { Number }\end{array}$ & $\begin{array}{c}\text { Mixed Solution } \\
\text { Bottle, } \mathrm{g}\end{array}$ & $\begin{array}{c}\text { Bottle + Cs test } \\
\text { solution, } \mathrm{g}\end{array}$ & $\begin{array}{c}\text { Bottle + Cs + Sr } \\
\text { test solution, }\end{array}$ & $\begin{array}{c}\text { Cs Dilution } \\
\text { Factor }\end{array}$ & $\begin{array}{c}\text { Sr Dilution } \\
\text { Factor }\end{array}$ \\
\hline SJ-A2-2 & 11.16 & 22.41 & 33.53 & 1.988 & 2.012 \\
\hline SJ-A2-3 & 11.18 & 22.20 & 33.26 & 2.004 & 1.996 \\
\hline SJ-B-0 & 11.16 & 22.79 & 34.34 & 1.993 & 2.007 \\
\hline SJ-B-3 & 11.21 & 22.57 & 33.76 & 1.985 & 2.015 \\
\hline SJ-B-4 & 11.24 & 21.89 & 32.80 & 2.024 & 1.976 \\
\hline SJ-B-5 & 11.18 & 22.11 & 33.20 & 2.015 & 1.986 \\
\hline SJ-C-0 & 11.18 & 23.11 & 34.77 & 1.977 & 2.023 \\
\hline SJ-C-3 & 11.26 & 22.56 & 33.75 & 1.990 & 2.010 \\
\hline SJ-C-4 & 11.21 & 22.31 & 33.27 & 1.987 & 2.013 \\
\hline SJ-C-5 & 11.11 & 22.15 & 33.11 & 1.993 & 2.007 \\
\hline SJ-D-0 & 11.19 & 22.86 & 34.57 & 2.003 & 1.997 \\
\hline SJ-D-3 & 11.19 & 22.26 & 33.43 & 2.009 & 1.991 \\
\hline SJ-D-4 & 11.11 & 22.18 & 31.05 & 1.801 & 2.248 \\
\hline SJ-D-5 & 11.20 & 22.20 & 33.14 & 1.995 & 2.005 \\
\hline SJ-E-0 & 11.19 & 22.88 & 34.60 & 2.003 & 1.997 \\
\hline SJ-E-3 & 11.17 & 22.42 & 33.62 & 1.996 & 2.004 \\
\hline SJ-E-4 & 11.16 & 22.20 & 33.24 & 2.000 & 2.000 \\
\hline SJ-E-5 & 11.20 & 22.22 & 33.35 & 2.010 & 1.990 \\
\hline SJ-F-0 & 11.23 & 22.98 & 34.66 & 1.994 & 2.006 \\
\hline SJ-F-3 & 11.23 & 22.39 & 33.55 & 2.000 & 2.000 \\
\hline SJ-F-4 & 11.17 & 22.35 & 33.46 & 1.994 & 2.006 \\
\hline SJ-F-5 & 11.10 & 22.18 & 32.82 & 1.960 & 2.041 \\
\hline SJ-F-0 & 11.11 & - & 22.92 & - & 1.003 \\
\hline
\end{tabular}

${ }^{\mathrm{a}}$ Repeat of blank test SJ1-Sr-F0.

Table 19. Solution results for tests using leachants with different $\mathrm{Cs}$ or $\mathrm{Sr}$ concentrations

\begin{tabular}{|c|c|c|c|c|}
\hline $\begin{array}{c}\text { Solution } \\
\text { Number }\end{array}$ & $\begin{array}{c}\text { Measured Cs, } \\
\mu \mathrm{g} / \mathrm{L}\end{array}$ & $\begin{array}{c}\text { Dil.-corrected Cs, } \\
\mu \mathrm{g} / \mathrm{L}\end{array}$ & $\begin{array}{c}\text { Mass Cs in test } \\
\text { solution, } \mu \mathrm{g}\end{array}$ & $\begin{array}{c}\text { Cs in test solution, } \\
\mu \mathrm{g} / \mathrm{mL}\end{array}$ \\
\hline SJ-A2-0 & 12300 & 24559 & 309 & 24.6 \\
\hline SJ-A2-1 & 552 & 1101 & 13.8 & 1.10 \\
\hline SJ-A2-2 & 573 & 1139 & 14.3 & 1.14 \\
\hline SJ-A2-3 & 531 & 1064 & 13.4 & 1.06 \\
\hline SJ-B-0 & 63200 & 125965 & 1583 & 126 \\
\hline SJ-B-3 & 6140 & 12188 & 153 & 12.2 \\
\hline SJ-B-4 & 5660 & 11458 & 144 & 11.5 \\
\hline SJ-B-5 & 5190 & 10456 & 131 & 10.5 \\
\hline SJ-C-0 & 6140 & 12141 & 153 & 12.1 \\
\hline SJ-C-3 & 182 & 362 & 4.55 & 0.362 \\
\hline SJ-C-4 & 164 & 326 & 4.10 & 0.326 \\
\hline SJ-C-5 & 150 & 299 & 3.76 & 0.299 \\
\hline SJ-D-0 & 1260 & 2524 & 31.7 & 2.52 \\
\hline SJ-D-3 & 11.3 & 22.7 & 0.285 & 0.0227 \\
\hline SJ-D-4 & 11.9 & 21.4 & 0.269 & 0.0214 \\
\hline SJ-D-5 & 7.47 & 14.9 & 0.188 & 0.0149 \\
\hline SJ-E-0 & 135 & 270 & 3.40 & 0.270 \\
\hline SJ-E-3 & 0.273 & 0.545 & 0.0069 & 0.0005 \\
\hline
\end{tabular}


Table 19. (cont.)

\begin{tabular}{|c|c|c|c|c|}
\hline $\begin{array}{c}\text { Solution } \\
\text { Number }\end{array}$ & $\begin{array}{c}\text { Measured Cs, } \\
\mu \mathrm{g} / \mathrm{L}\end{array}$ & $\begin{array}{c}\text { Dil.-corrected } \\
\mathrm{Cs}, \mu \mathrm{g} / \mathrm{L}\end{array}$ & $\begin{array}{c}\text { Mass Cs in test } \\
\text { solution, } \mu \mathrm{g}\end{array}$ & $\begin{array}{c}\text { Cs in test solution, } \\
\mu \mathrm{g} / \mathrm{mL}\end{array}$ \\
\hline SJ-E-4 & 0.203 & 0.406 & 0.0051 & 0.0004 \\
\hline SJ-E-5 & 0.147 & 0.296 & 0.0037 & 0.0003 \\
\hline SJ-F-0 & 3140 & 6261 & 78.69 & 6.26 \\
\hline SJ-F-3 & 52.5 & 105 & 1.32 & 0.105 \\
\hline SJ-F-4 & 53.5 & 107 & 1.34 & 0.107 \\
\hline SJ-F-5 & 47.6 & 93.3 & 1.17 & 0.0933 \\
\hline
\end{tabular}

\begin{tabular}{|c|c|c|c|c|}
\hline $\begin{array}{c}\text { Solution } \\
\text { Number }\end{array}$ & $\begin{array}{c}\text { Measured Sr, } \\
\mu \mathrm{g} / \mathrm{L}\end{array}$ & $\begin{array}{c}\text { Dil.-corrected } \\
\mathrm{Sr}, \mu \mathrm{g} / \mathrm{L}\end{array}$ & $\begin{array}{c}\text { Mass Sr in test } \\
\text { solution, } \mu \mathrm{g}\end{array}$ & $\begin{array}{c}\text { Sr in test solution, } \\
\mu \mathrm{g} / \mathrm{mL}\end{array}$ \\
\hline SJ-A2-0 & 7360 & 14745 & 185 & 14.7 \\
\hline SJ-A2-1 & 528 & 1059 & 13.3 & 1.06 \\
\hline SJ-A2-2 & 528 & 1062 & 13.3 & 1.06 \\
\hline SJ-A2-3 & 484 & 966 & 12.1 & 0.966 \\
\hline SJ-B-0 & 18000 & 36125 & 453 & 36.1 \\
\hline SJ-B-3 & 1890 & 3809 & 47.8 & 3.81 \\
\hline SJ-B-4 & 1730 & 3419 & 42.9 & 3.42 \\
\hline SJ-B-5 & 2580 & 5123 & 64.3 & 5.12 \\
\hline SJ-C-0 & 3860 & 7809 & 98.0 & 7.81 \\
\hline SJ-C-3 & 276 & 555 & 6.96 & 0.555 \\
\hline SJ-C-4 & 289 & 582 & 7.30 & 0.582 \\
\hline SJ-C-5 & 252 & 506 & 6.35 & 0.506 \\
\hline SJ-D-0 & 772 & 1541 & 19.3 & 1.54 \\
\hline SJ-D-3 & 114 & 227 & 2.85 & 0.227 \\
\hline SJ-D-4 & 113 & 254 & 2.55 & 0.254 \\
\hline SJ-D-5 & 102 & 205 & 2.57 & 0.205 \\
\hline SJ-E-0 & 82.8 & 165 & 2.08 & 0.165 \\
\hline SJ-E-3 & 76.4 & 153 & 1.92 & 0.153 \\
\hline SJ-E-4 & 81.7 & 163 & 2.05 & 0.163 \\
\hline SJ-E-5 & 69.9 & 139 & 1.75 & 0.139 \\
\hline SJ-F-0 & $790^{\mathrm{b}}$ & $1585^{\mathrm{b}}$ & $19.9^{\mathrm{b}}$ & $1.58^{\mathrm{b}}$ \\
\hline SJ-F-3 & 164 & 328 & 4.11 & 0.328 \\
\hline SJ-F-4 & 170 & 341 & 4.28 & 0.341 \\
\hline SJ-F-5 & 98.1 & 200 & 2.51 & 0.200 \\
\hline SJ-F-0 & 3830 & 3840 & 48.0 & 3.84 \\
\hline
\end{tabular}

${ }^{b}$ Results of blank test SJ1-Sr-F0 rejected.

${ }^{\mathrm{c}}$ Repeat of blank test SJ1-Sr-F0 solution was not mixed with Cs solution.

\begin{tabular}{|c|c|c|c|c|c|}
\hline Test Number & $\begin{array}{c}\text { Volume Cs } \\
\text { Leachant, } \mathrm{mL}\end{array}$ & $\begin{array}{c}\text { Mass Cs in } \\
\text { Leachant, } \mu \mathrm{g}\end{array}$ & $\begin{array}{c}\text { Mass Cs on } \\
\text { soil, } \mu \mathrm{g}\end{array}$ & $\mu \mathrm{g}$ Cs/g soil & $\begin{array}{c}K_{\mathrm{d}}(\mathrm{Cs}) \\
\mathrm{mL} / \mathrm{g}\end{array}$ \\
\hline SJ1-Cs-A2-0 & 12.58 & 309 & - & - & - \\
\hline SJ1-Cs-A2-1 & 12.57 & 309 & 295 & 590 & 535.5 \\
\hline SJ1-Cs-A2-2 & 12.59 & 309 & 295 & 590 & 517.4 \\
\hline SJ1-Cs-A2-3 & 12.57 & 309 & 295 & 591 & 555.0 \\
\hline SJ1-Cs-B-0 & 12.57 & 1583 & - & - & - \\
\hline SJ1-Cs-B-3 & 12.57 & 1583 & 1430 & 2860 & 234.6 \\
\hline SJ1-Cs-B-4 & 12.58 & 1584 & 1440 & 2880 & 251.4 \\
\hline SJ1-Cs-B-5 & 12.57 & 1583 & 1452 & 2903 & 277.7 \\
\hline
\end{tabular}


Table 19 (cont.)

\begin{tabular}{|c|c|c|c|c|c|}
\hline Test Number & $\begin{array}{c}\text { Volume Cs } \\
\text { Leachant, } \mathrm{mL}\end{array}$ & $\begin{array}{c}\text { Mass Cs in } \\
\text { Leachant, } \mu \mathrm{g}\end{array}$ & $\begin{array}{c}\text { Mass Cs on } \\
\text { soil, } \mu \mathrm{g}\end{array}$ & $\mu \mathrm{g}$ Cs/g soil & $\begin{array}{c}K_{\mathrm{d}}(\mathrm{Cs}) \\
\mathrm{mL} / \mathrm{g}\end{array}$ \\
\hline SJ1-Cs-C-0 & 12.58 & 153 & - & - & - \\
\hline SJ1-Cs-C-3 & 12.57 & 153 & 148 & 296 & 817.3 \\
\hline SJ1-Cs-C-4 & 12.57 & 153 & 148 & 297 & 911.1 \\
\hline SJ1-Cs-C-5 & 12.57 & 153 & 148 & 298 & 995.8 \\
\hline SJ1-Cs-D-0 & 12.57 & 31.7 & - & - & - \\
\hline SJ1-Cs-D-3 & 12.57 & 31.7 & 31.4 & 62.9 & 2770 \\
\hline SJ1-Cs-D-4 & 12.57 & 31.7 & 31.5 & 62.9 & 2935 \\
\hline SJ1-Cs-D-5 & 12.60 & 31.8 & 31.6 & 63.2 & 4243 \\
\hline SJ1-Cs-E-0 & 12.57 & 3.40 & - & - & - \\
\hline SJ1-Cs-E-3 & 12.58 & 3.40 & 3.39 & 6.79 & 12460 \\
\hline SJ1-Cs-E-4 & 12.57 & 3.40 & 3.39 & 6.78 & 16710 \\
\hline SJ1-Cs-E-5 & 12.58 & 3.40 & 3.40 & 6.79 & 22990 \\
\hline SJ1-Cs-F-0 & 12.57 & 78.7 & - & - & - \\
\hline SJ1-Cs-F-3 & 12.60 & 78.9 & 77.6 & 155 & 1477 \\
\hline SJ1-Cs-F-4 & 12.57 & 78.7 & 77.3 & 155 & 1450 \\
\hline SJ1-Cs-F-5 & 12.57 & 78.7 & 77.5 & 155 & 1661 \\
\hline
\end{tabular}

\begin{tabular}{|c|c|c|c|c|c|}
\hline Test Number & $\begin{array}{c}\text { Volume Sr } \\
\text { Leachant, } \mathrm{mL}\end{array}$ & $\begin{array}{c}\text { Mass Sr in } \\
\text { Leachant, } \mu \mathrm{g}\end{array}$ & $\begin{array}{c}\text { Mass Sr on } \\
\text { soil, } \mu \mathrm{g}\end{array}$ & $\mu \mathrm{g}$ Sr/g soil & $\begin{array}{c}K_{\mathrm{d}}(\mathrm{Sr}) \\
\mathrm{mL} / \mathrm{g}\end{array}$ \\
\hline SJ2-Sr-A2-0 & 12.55 & 185 & - & - & - \\
\hline SJ2-Sr-A2-1 & 12.54 & 185 & 172 & 343 & 324.3 \\
\hline SJ2-Sr-A2-2 & 12.54 & 185 & 172 & 343 & 323.2 \\
\hline SJ2-Sr-A2-3 & 12.55 & 185 & 173 & 346 & 358.0 \\
\hline SJ1-Sr-B-0 & 12.55 & 453 & - & - & - \\
\hline SJ1-Sr-B-3 & 12.54 & 453 & 405 & 811 & 212.9 \\
\hline SJ1-Sr-B-4 & 12.54 & 453 & 410 & 821 & 240.0 \\
\hline SJ1-Sr-B-5 & 12.54 & 453 & 389 & 778 & 151.8 \\
\hline SJ1-Sr-C-0 & 12.54 & 98.0 & - & - & - \\
\hline SJ1-Sr-C-3 & 12.54 & 98.0 & 91.0 & 182 & 328.1 \\
\hline SJ1-Sr-C-4 & 12.55 & 98.0 & 90.7 & 181 & 312.0 \\
\hline SJ1-Sr-C-5 & 12.55 & 98.0 & 91.7 & 183 & 362.5 \\
\hline SJ1-Sr-D-0 & 12.54 & 19.3 & - & - & - \\
\hline SJ1-Sr-D-3 & 12.55 & 19.3 & 16.5 & 33.0 & 145.4 \\
\hline SJ1-Sr-D-4 & 10.04 & 15.5 & 12.9 & 32.3 & 127.3 \\
\hline SJ1-Sr-D-5 & 12.54 & 19.3 & 16.8 & 33.5 & 163.9 \\
\hline SJ1-Sr-E-0 & 12.55 & 2.08 & - & - & - \\
\hline SJ1-Sr-E-3 & 12.54 & 2.07 & 0.154 & 0.307 & 2.006 \\
\hline SJ1-Sr-E-4 & 12.57 & 2.08 & 0.0250 & 0.050 & 0.306 \\
\hline SJ1-Sr-E-5 & 12.56 & 2.08 & 0.330 & 0.660 & 4.747 \\
\hline SJ1-Sr-F-0 & 12.54 & $-b$ & $-b$ & $-b$ & - \\
\hline SJ1-Sr-F-3 & 12.54 & 48.0 & 43.9 & 87.9 & 267.8 \\
\hline SJ1-Sr-F-4 & 12.55 & 48.1 & 43.8 & 87.6 & 256.8 \\
\hline SJ1-Sr-F-5 & 12.55 & 48.1 & 45.6 & 91.1 & 455.1 \\
\hline SJ1-Sr-F-0 & 12.54 & 48.0 & - & - & - \\
\hline bea & & & & \\
\hline
\end{tabular}

${ }^{a}$ Repeat of blank test SJ1-Sr-F0.

${ }^{\mathrm{b}}$ Results of blank test SJ1-Sr-F0 rejected.

${ }^{\mathrm{c}}$ Calculated using concentration in $\mathrm{Sr}$ A2 solution to be consistent with other tests in this series. 


\section{Linear Isotherm Model}

In the linear isotherm model, the amount taken up by the soil is proportional to the amount in the test solution as in the definition of $K_{\mathrm{d}}$ :

$($ concentration on solid $)=K_{\mathrm{d}} \times($ concentration in solution $)$.

Linear plots of the Cs and $\mathrm{Sr}$ test results are given in Figures 11 and 12, respectively. Figure 11a shows the mass of Cs taken up by the soil to be linear with the mass of Cs in the initial solution, but Figure 11b shows that the mass of Cs taken up by the soil is not linearly related to the mass of Cs remaining in the solution. Rather, the amounts taken up by the soil at low solution concentrations is related to the solution equilibrium concentration by an empirical power law relationship. Figure 11c shows that the amounts taken up by the soil at higher concentrations are greater than what is predicted based on the relationship followed at low solution concentrations. This may reflect a change in mechanism, such as the added contribution of precipitation to the observed uptake at high $\mathrm{CsCl}$ concentrations.

The mass of Sr taken up by the soil is likewise linear with the mass of $\mathrm{Sr}$ in the initial solution, as shown in Figure 12a. Figure 12b shows the mass of $\mathrm{Sr}$ taken up by the soil is linearly related to the mass of $\mathrm{Sr}$ remaining in the solution at low concentrations, but Figure 12c shows the correlation does not extend to higher concentrations, where the amount of $\mathrm{Sr}$ on the soil is significantly lower than predicted based on the lower solution concentrations. This may indicate that the surface capacity for $\mathrm{Sr}$ has been reached, but addition tests are needed to confirm that hypothesis. Note that the fitted lines in Figure 12b show no $\mathrm{Sr}$ is taken up by the soil at $\mathrm{Sr}$ solution concentrations below about $0.1 \mu \mathrm{g} / \mathrm{mL}$. Since the amount taken up by the soil is calculated by subtracting the amount remaining in the test solution from the amount provided in the leachant, this means that $\mathrm{Sr}$ has been added from another source. This is consistent with the findings in the soil blank tests of Sr solution concentrations of $0.090,0.080$, and $0.125 \mu \mathrm{g} / \mathrm{mL}$ after reacting 1, 3, and 7 days in demineralized water, and indicates that $\mathrm{Sr}$ is being released from the soil during the tests, presumably due to the dissolution of a Sr-bearing phase, even as $\mathrm{Sr}$ is being taken up by the soil. Similar amounts of $\mathrm{Sr}$ were measured in tests conducted with the Cs solutions in the repeatability test series that were not mixed with $\mathrm{Sr}$ test solutions for analysis. While further analyses are needed to determine the processes that are occurring, this is an example of the convoluted processes that are empirically quantified using the distribution coefficient and the sensitivity of the $K_{\mathrm{d}}$ value to both the conditions of the soil and leachant used in the test and the testing parameters.

The Sr results are shown with a single line having a slope of 1 with the value at $x=0$ equal to the average value of $\log K_{\mathrm{F}}$ for all results (regardless of test duration) except the tests with the lowest $\mathrm{Sr}$ concentration, which are shown as open symbols. Exclusion of the results for the lowest concentration is justified by the fact that these results are dominated by the effect of Sr release from the soil. The parameter values for the linear isotherms for tests conducted for different durations are summarized in Table 20. The values of the $x$-intercept values give the solution concentrations when no $\mathrm{Sr}$ is calculated to be sorbed to the soil, based on the leachant and test solution concentrations. This represents the additional $\mathrm{Sr}$ that is released from the soil during the test.

Table 20. Values of $K_{\mathrm{d}}(\mathrm{Sr})$ calculated from the linear isotherm model

\begin{tabular}{|c|c|c|c|}
\hline \multirow{3}{*}{$\mathrm{Sr}$} & $\begin{array}{c}\text { Duration, } \\
\text { days }\end{array}$ & $\begin{array}{c}K_{\mathrm{d}}(\mathrm{Sr}), \\
\mathrm{mL} / \mathrm{g}\end{array}$ & $\begin{array}{c}x \text {-intercept Sr, } \\
\mu \mathrm{g} / \mathrm{mL}\end{array}$ \\
\cline { 2 - 4 } & 1 & 376 & 0.120 \\
\cline { 2 - 4 } & 2 & 382 & 0.143 \\
\hline
\end{tabular}




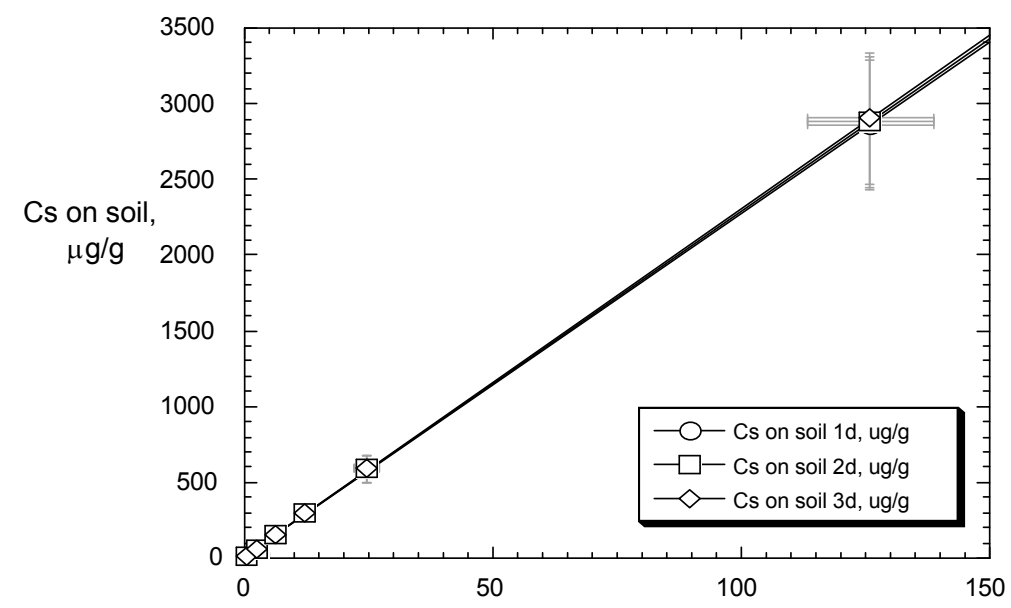

(a)

Cs in leachant, $\mu \mathrm{g} / \mathrm{mL}$

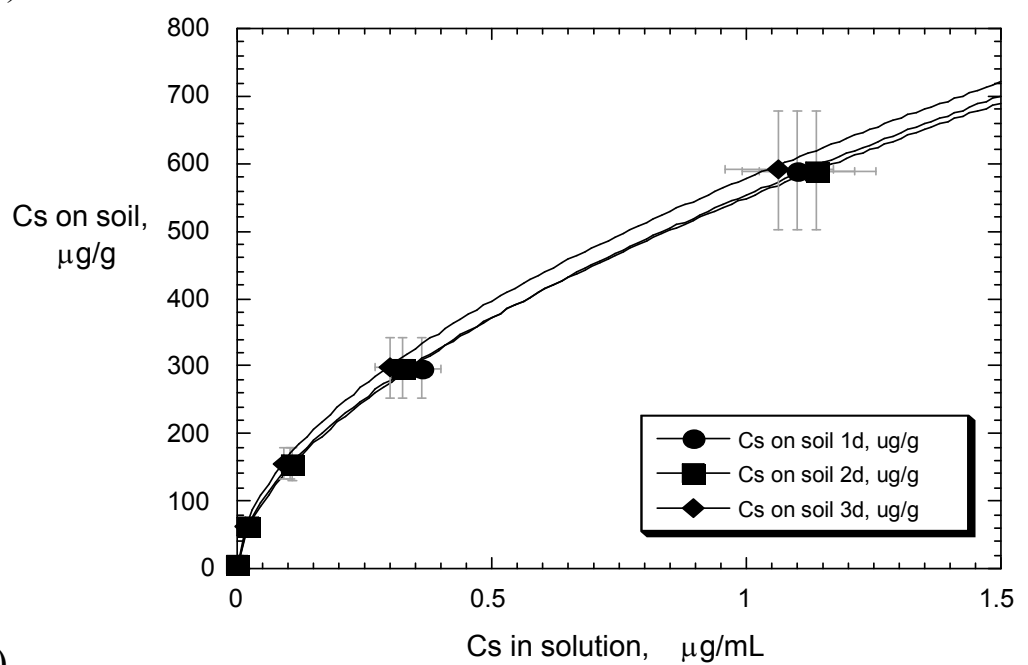

(b)

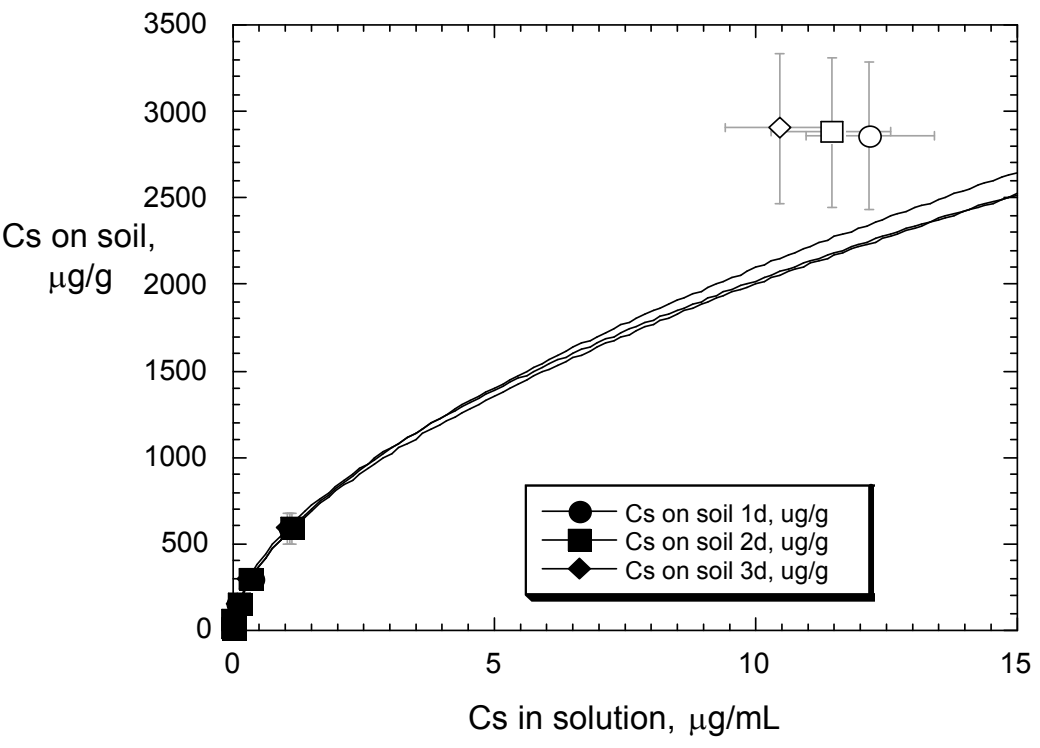

Figure 11. Correlation between Cs uptake onto soil and (a) Cs concentration in leachant prior to equilibration, (b) and (c) Cs concentration in solution after equilibration at low and high concentrations. 


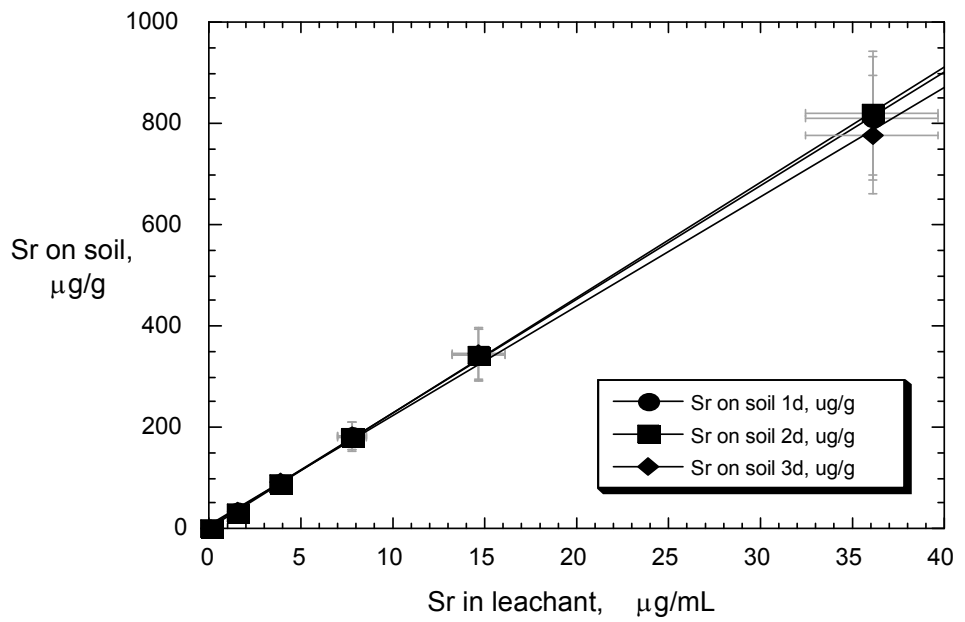

(a)

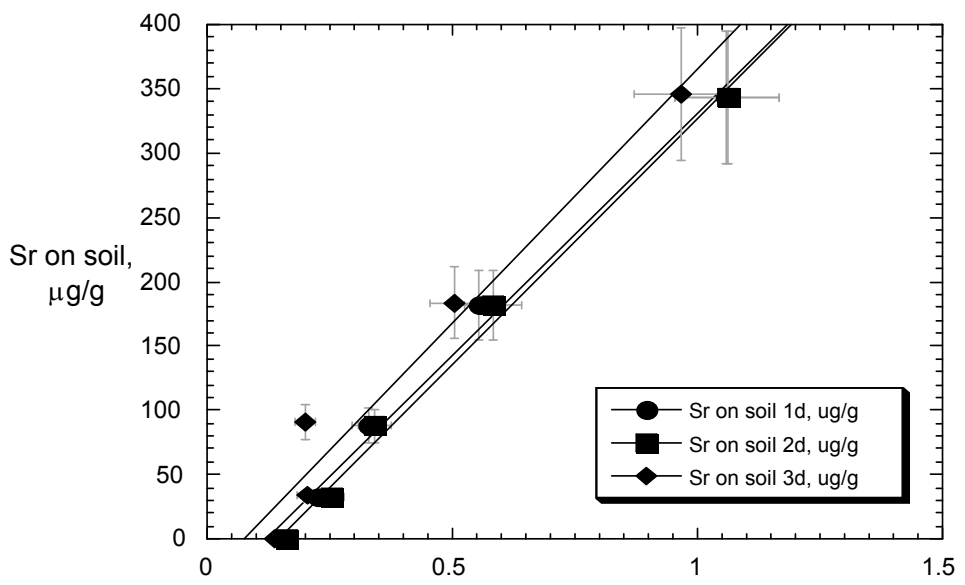

(b)

Sr in solution, $\mu \mathrm{g} / \mathrm{mL}$

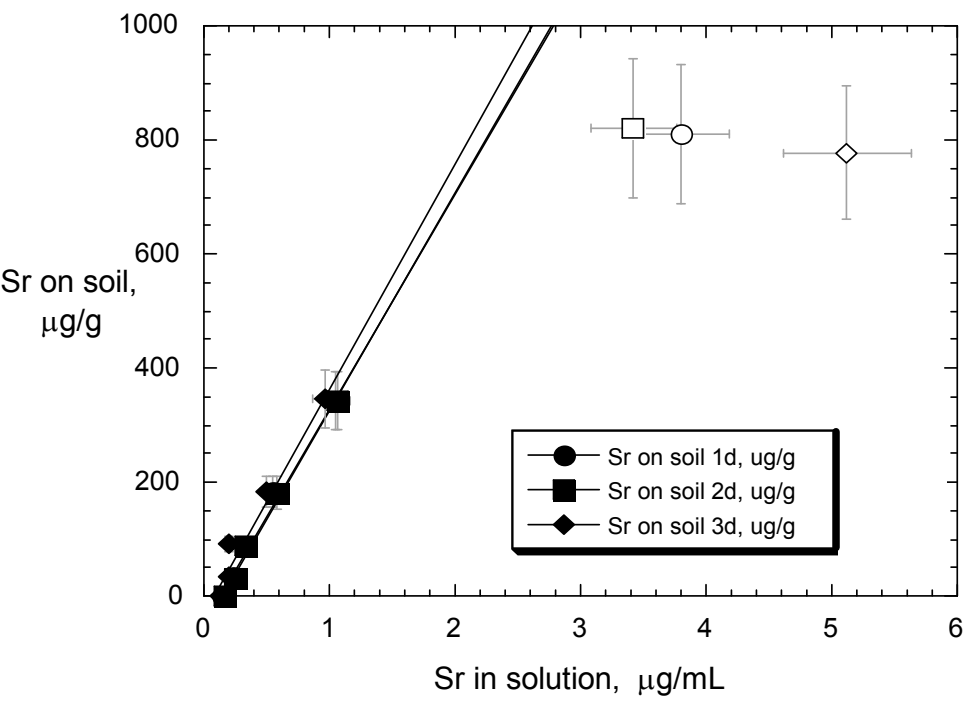

Figure 12. Correlation between Sr uptake onto soil and (a) Sr concentration in leachant prior to equilibration, (b) and (c) Sr concentration in solution after equilibration. The Sr B series solutions are shown as open symbols and were excluded from the regression. 


\section{Freundlich Isotherm Model}

The Freundlich isotherm is a simple extension of the linear model that has the general form

concentration on solid $=K_{\mathrm{F}} \times(\text { concentration in solution })^{n}$

where $K_{\mathrm{F}}$ and $n$ are constants, and is applied to systems at equilibrium. The Freundlich model allows for multilayer formation, whereas the Langumuir model discussed below is restricted to a monolayer. The linear isotherm is a special conditions of the Freundlich isotherm with $n=1$, in which case Equation 7 is equivalent to Equation 1 and $K_{\mathrm{F}}$ equals $K_{\mathrm{d}}$. In this case, a plot of the concentration on the solid versus the concentration in solution is expected to give a straight line with slope $K_{\mathrm{d}}$ that passes through the origin. The Freundlich isotherm expression can be linearized to evaluate systems for which $n \neq 1$ by taking the logarithm of Equation 8

$\log [\mathrm{Cs}]_{\text {soil }}=\log K_{\mathrm{F}}+n \log [\mathrm{Cs}]_{\text {solution }}$

Plotting the logarithms of the concentrations should result in a linear fit with the slope providing the value of $n$ and a $y$-intercept (i.e., the $y$ value when $\log x=0$ ) providing the value $\log K_{\mathrm{F}}$. Figures $13 \mathrm{a}$ and $13 \mathrm{~b}$ show the Cs and Sr uptakes in a log-log plot fit with Freundlich isotherms. The Cs results for the series tests run at each duration are regressed separately. The equations of the regressed lines are

for 1-day tests: $y=2.77+0.593 x$

for 2-day tests: $y=2.78+0.583 x$

for 1-day tests: $y=2.81+0.568 x$

where $y$ is $\log [\mathrm{Cs}]_{\text {soil }}$ and $x$ is $\log [\mathrm{Cs}]_{\text {solution. }}$. The slope of each equation gives $n$ and the $y$-intercept gives $\log K_{\mathrm{F}}$. Note that Equation 8 has the same form as the power law used to empirically fit the Cs results as shown in Figure 11b and extrapolated in Figure 11c, and the parameter values are the same. Values of $n$ significantly less than 1 indicate the the surface is heterogeneous with regard to the uptake of Cs. From the definition of $K_{\mathrm{d}}$, the values of $K_{\mathrm{d}}$ and $K_{\mathrm{d}}$ are related as

$$
K_{d}=\frac{[C s]_{\text {soil }}}{[C s]_{\text {solution }}}=K_{F} \times[C s]_{\text {solution }}{ }^{n-1}
$$

Values of $K_{\mathrm{d}}$ determined for the experimental concentrations are given in Table 21.

Table 21. Values of $K_{\mathrm{d}}(\mathrm{Cs})$ calculated from the Freundlich isotherm

\begin{tabular}{|c|c|c|c|c|c|}
\hline \multicolumn{2}{|c|}{1 day } & \multicolumn{2}{|c|}{2 days } & \multicolumn{2}{|c|}{3 days } \\
\hline$n=0.593$ & $K_{\mathrm{F}}=589$ & $n=0.583$ & $K_{\mathrm{F}}=603$ & $n=0.56$ & $K_{\mathrm{F}}=646$ \\
\hline $\begin{array}{c}\text { Cs in solution, } \\
\mu \mathrm{g} / \mathrm{mL}\end{array}$ & $K_{\mathrm{d}}(\mathrm{Cs}), \mathrm{mL} / \mathrm{g}$ & $\begin{array}{c}\text { Cs in solution, } \\
\mu \mathrm{g} / \mathrm{mL}\end{array}$ & $K_{\mathrm{d}}(\mathrm{Cs}), \mathrm{mL} / \mathrm{g}$ & $\begin{array}{c}\text { Cs in solution, } \\
\mu \mathrm{g} / \mathrm{mL}\end{array}$ & $K_{\mathrm{d}}(\mathrm{Cs}), \mathrm{mL} / \mathrm{g}$ \\
\hline 0.000545 & 12500 & 0.000406 & 15700 & 0.000296 & 21600 \\
\hline 0.0227 & 2750 & 0.0214 & 3000 & 0.0149 & 3980 \\
\hline 0.105 & 1470 & 0.107 & 1530 & 0.0933 & 1800 \\
\hline 0.362 & 891 & 0.326 & 962 & 0.299 & 1090 \\
\hline 1.10 & 566 & 1.14 & 571 & 1.06 & 629 \\
\hline 12.2 & 213 & 11.5 & 218 & 10.5 & 234 \\
\hline
\end{tabular}


The pooled Sr test results in Figure $13 \mathrm{~b}$ show linear behavior at high concentrations, but the regressed line does not pass through the origin. This is a result of $\mathrm{Sr}$ being released from the soil into solution during the test. Since the amount of $\mathrm{Sr}$ released from the soil may depend on the Sr solution concentration, how this should be taken into account when calculating $K_{\mathrm{d}}$ is not obvious. The equation of the regressed line in Figure 13b for tests with the higher solution concentrations is

Sr: $y=2.398+0.9856 x \quad\left(\mathrm{R}^{2}=0.885\right)$

from which $n=0.986$ and $K_{\mathrm{F}}=250.0$. The observation that the value of $n$ is very near 1 is consistent with the fit to the linear isotherm and the effective uniformity of the soil with respect to Sr sorption.

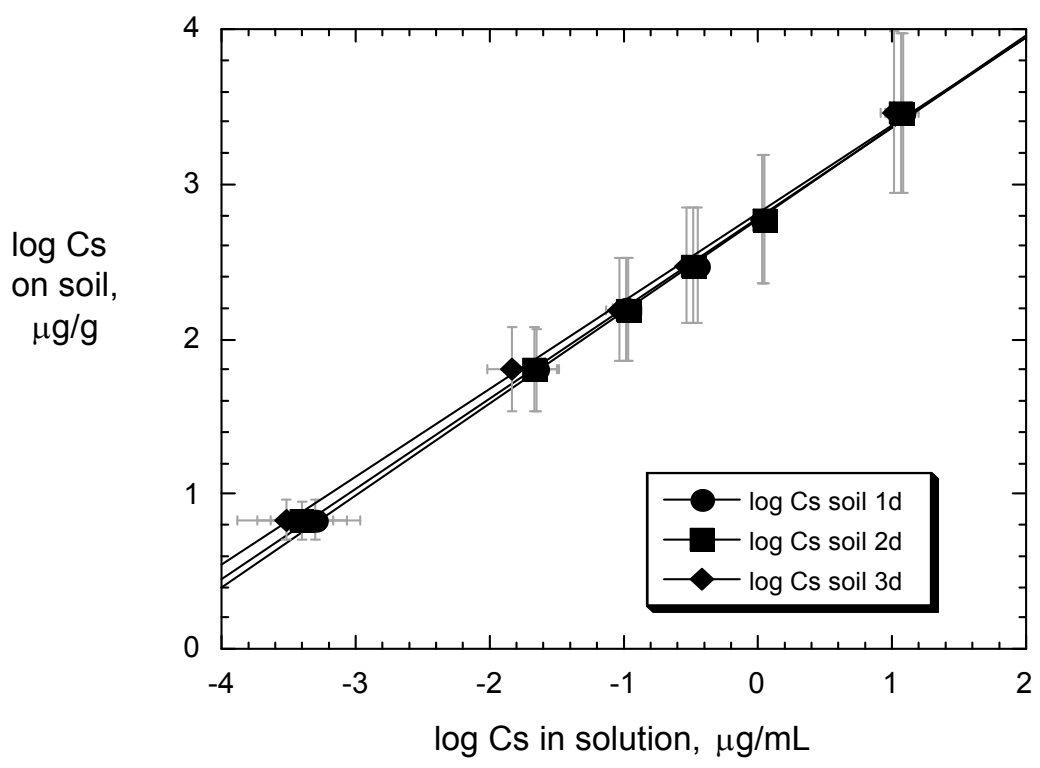

(a)

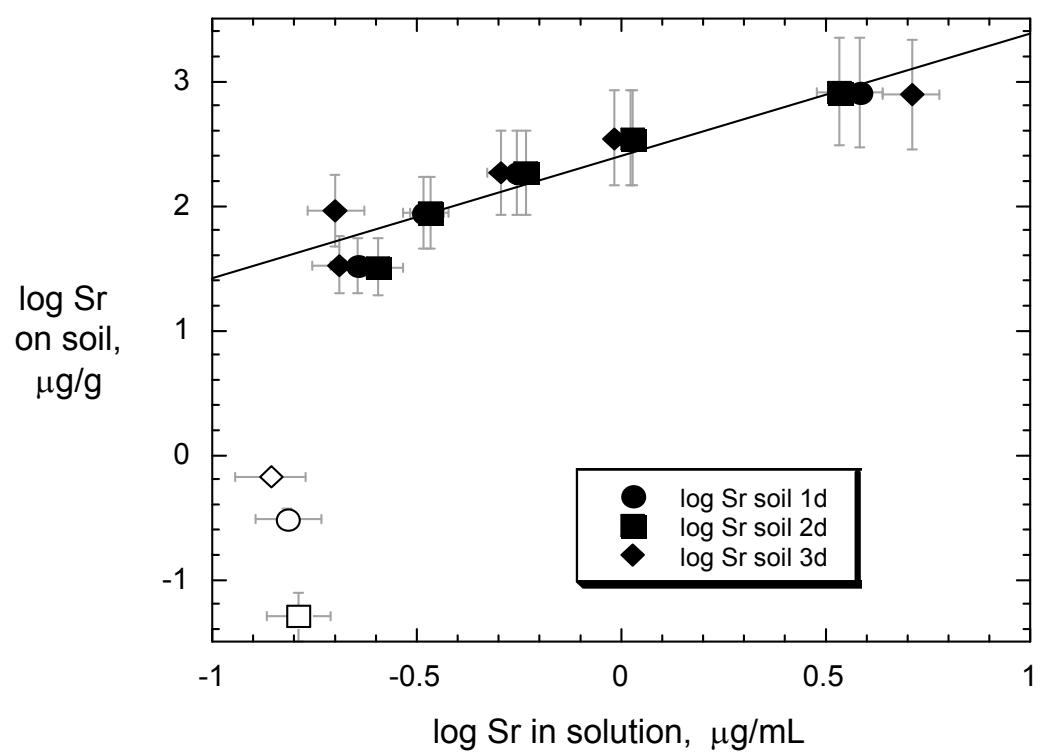

(b)

Figure 13. Evaluation of concentration effects using Freundlich isotherm model for tests with (a) Cs and (b) Sr. Results for the Sr E solution are shown as open symbols and were excluded from the regression. 


\section{Langmuir Isotherm Model}

The Langmuir model addresses a sorption of a single species on a uniform surface with a maximum coverage of one monolayer. The isotherm equation has the form

$$
C_{\text {soil }}=b \frac{K_{\mathrm{L}} C_{\text {solution }}}{\left(1+K_{L} C_{\text {solution }}\right)}
$$

where $b$ is the sorption capacity of the soil (i.e., the maximum value of $C_{\text {soil }}$ ) and $K_{\mathrm{L}}$ is the Langmuir constant. This can be rearranged to a linear form that can be used to determine the model parameter values from experimental data as

$$
\frac{C_{\text {solution }}}{C_{\text {soil }}}=\frac{1}{b K_{\mathrm{L}}}+\frac{C_{\text {solution }}}{b}
$$

A plot of $\mathrm{C}_{\text {solution }} / \mathrm{C}_{\text {soil }}$ against $\mathrm{C}_{\text {solution }}$ will yield a straight line with slope $b^{-1}$ and intercept $\left(b K_{\mathrm{L}}\right)^{-1}$. Data used for the Langmuir plots are provided in Table 22. Results for tests conducted a low concentrations of $\mathrm{Cs}$ and $\mathrm{Sr}$ in Figures 14a and 14b do not show Langmuir behavior. The results for tests with the D, E, and F solutions are shown as open symbols and were excluded from the linear fits, and the Sr results for the E solutions were excluded from the plot. The pooled results from 1-, 2-, and 3-day tests using higher concentrations were fit with the following equations:

Cs: $\quad y=0.00130+0.000235 x \quad\left(\mathrm{R}^{2}=0.958\right)$

Sr: $y=0.00241+0.000688 x \quad\left(\mathrm{R}^{2}=0.905\right)$

Table 22. Data used in Langmuir isotherm plots

\begin{tabular}{|l|c|c|c|c|}
\hline Test Solution & $\begin{array}{c}\mathrm{Cs}_{\text {solution, }}, \\
\mathrm{g} / \mathrm{mL}\end{array}$ & $\begin{array}{c}\mathrm{Cs}_{\text {solution }} / \mathrm{Cs}_{\text {soill }}, \\
\mathrm{mL} / \mathrm{g}\end{array}$ & $\begin{array}{c}\mathrm{Sr}_{\text {solution, }}, \\
\mathrm{g} / \mathrm{mL}\end{array}$ & $\begin{array}{c}\mathrm{Sr}_{\text {solution }} / \mathrm{Sr}_{\text {soi }}, \\
\mathrm{mL} / \mathrm{g}_{1}\end{array}$ \\
\hline SJ-A2-1 & 1.10 & 0.001864 & 1.06 & 0.003090 \\
\hline SJ-B-3 & 12.2 & 0.004266 & 3.81 & 0.004698 \\
\hline SJ-C-3 & 0.362 & 0.001223 & 0.555 & 0.003050 \\
\hline SJ-D-3 & 0.0227 & 0.000361 & 0.227 & 0.006879 \\
\hline SJ-E-3 & 0.000500 & 0.000074 & 0.153 & 0.498370 \\
\hline SJ-F-3 & 0.105 & 0.000677 & 0.328 & 0.003732 \\
\hline SJ-A2-2 & 1.14 & 0.001932 & 1.06 & 0.003090 \\
\hline SJ-B-4 & 11.5 & 0.003993 & 3.42 & 0.004166 \\
\hline SJ-C-4 & 0.326 & 0.001098 & 0.582 & 0.003216 \\
\hline SJ-D-4 & 0.0214 & 0.000340 & 0.254 & 0.007864 \\
\hline SJ-E-4 & 0.000406 & 0.000060 & 0.163 & 3.2600 \\
\hline SJ-F-4 & 0.107 & 0.000690 & 0.341 & 0.003893 \\
\hline SJ-A2-3 & 1.06 & 0.001793 & 0.966 & 0.002792 \\
\hline SJ-B-5 & 10.5 & 0.003617 & 5.12 & 0.006581 \\
\hline SJ-C-5 & 0.299 & 0.001003 & 0.506 & 0.002765 \\
\hline SJ-D-5 & 0.0149 & 0.000236 & 0.205 & 0.006119 \\
\hline SJ-E-5 & 0.000296 & 0.000044 & 0.139 & 0.21061 \\
\hline SJ-F-5 & 0.0933 & 0.000602 & 0.200 & 0.002195 \\
\hline
\end{tabular}




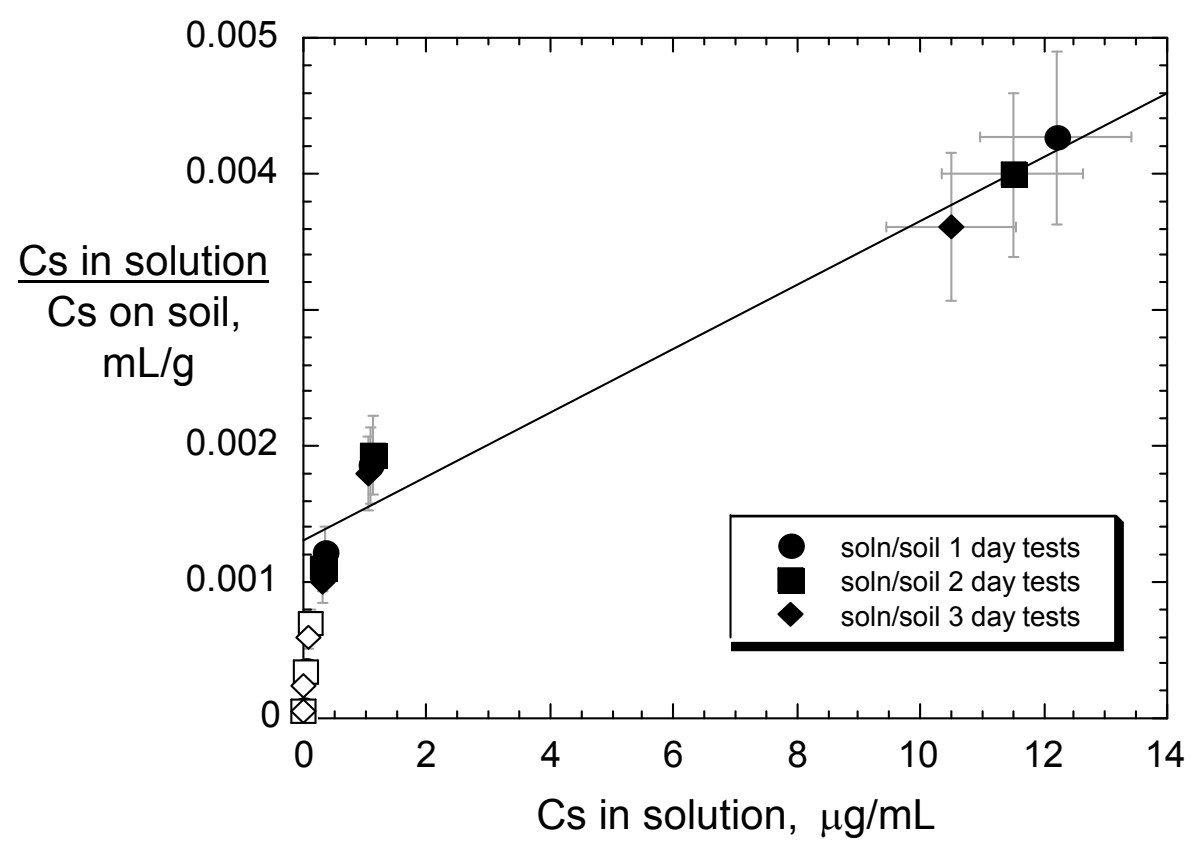

(a)

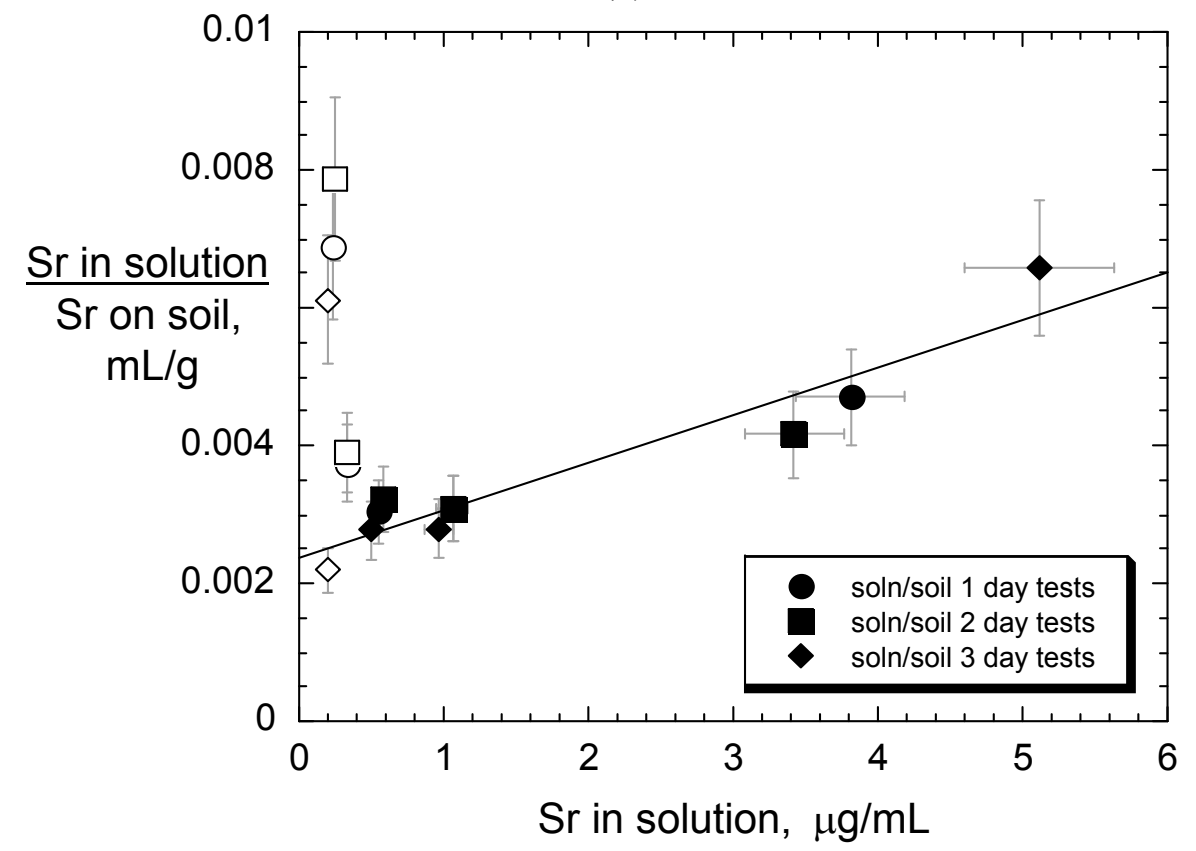

(b)

Figure 14. Evaluation of concentration effects using Langmuir isotherm model for tests with (a) Cs and (b) Sr. Results for the Cs and Sr D, E, and F solution tests are shown as open symbols; Results for the Sr E solution tests were excluded from the plot.

Based on the plotted values, the units of $b$ are the same as $\mathrm{C}_{\text {soil }}(\mu \mathrm{g} / \mathrm{g})$ and the units of $b K_{\mathrm{L}}$ are $\mathrm{mL} / \mathrm{g}$, so the corresponding units of $K_{\mathrm{F}}$ are $\mathrm{mL} / \mu \mathrm{g}$. From the Cs plot, $b=4255 \mu \mathrm{g} \mathrm{Cs} / \mathrm{g}$ soil, $b K_{\mathrm{L}}=769.2 \mathrm{~mL} / \mathrm{g}$, and $K_{\mathrm{L}}=0.181 \mathrm{~mL} / \mu \mathrm{g} \mathrm{Cs}=1.81 \times 10^{5} \mathrm{~mL} / \mathrm{g}$ Cs. From the Sr plot, $b=1453 \mu \mathrm{g} \mathrm{Sr} / \mathrm{g}$ soil $b K_{\mathrm{L}}=414.9$ $\mathrm{mL} / \mathrm{g}$, and $K_{\mathrm{L}}=0.285 \mathrm{~mL} / \mu \mathrm{g} \mathrm{Sr}=2.85 \times 10^{5} \mathrm{~mL} / \mathrm{g} \mathrm{Sr}$. 


\subsection{Confirmation Tests}

Two series of tests were conducted to confirm the conclusions drawn from the series of tests discussed above. Five replicate tests were conducted to provide a measure of the within-laboratory precision under the conditions recommended for the interlaboratory study (see Section 4.2). These were done due to the added calculations that were required due to our using the wrong solutions in the original series (see Section 3.4). Six tests were conducted to measure the effect of scale over the range of soil mass from 1 to $5 \mathrm{~g}$, as identified in $\mathrm{C} 1733$. The original tests were conducted with a maximum of $1.5 \mathrm{~g}$ soil. These were also conducted to further evaluate if the effect of scale seen in Figure 5 was real.

\section{Replicate Tests}

Five replicate tests were conducted to demonstrate the approach for the interlaboratory study that is proposed above (see Section 4.2). Soil from Jar 1 and Jar 2 were combined (11.54 g from Jar 1 and $21.76 \mathrm{~g}$ from Jar 2) and mechanically mixed. A solution of $\mathrm{CsCl}$ referred to as Solution $\mathrm{G}$ was prepared in the silicate solution $\left(0.0139 \mathrm{~g} \mathrm{CsCl}+0.0892 \mathrm{~g} \mathrm{NaHCO}_{3}+0.0511 \mathrm{~g} \mathrm{SiO}_{2} \mathrm{H}_{2} \mathrm{O}+3\right.$ drops $\left.\mathrm{HNO}_{3}\right)$ diluted to $500 \mathrm{~g}$ with demineralized water and then adjusted to 8.455 by adding a small amount of dilute $\mathrm{NaOH}$. Tests were conducted in Teflon vessels at $30.0^{\circ} \mathrm{C}$ for 48.00 hours. The vessels were rocked to suspend the soil several times over the test interval. At the end of the test duration, the vessels were opened and about $10 \mathrm{~mL}$ of solution was decanted into syringe filters and passed through $450 \mathrm{~nm}$-pore-size cellulose filters into solution bottles. The test data are summarized in Table 23. The filtrates were acidified with 4 drops of concentrated $\mathrm{HNO}_{3}$ and analyzed with ICP-MS. The analytical results are summarized in Table 24. The Cs concentration in the blank test with Leachant $\mathrm{G}$ was measured to be $17200 \mathrm{~g} / \mathrm{L}$, which is $9.25 \times 10^{-5} \underline{\mathrm{m}} \mathrm{CsCl}$. As before, the mass sorbed to the soil was calculated from difference between the mass of Cs in the leachant and the mass remaining in solution. The sorbed mass was normalized to the mass of soil used in the test and used to calculate $K_{\mathrm{d}}(\mathrm{Cs})$ for each test.

Table 23. Data for replicate tests with Leachant G

\begin{tabular}{|c|c|c|c|c|}
\hline Test Number & $\begin{array}{c}\text { Duration, } \\
\mathrm{h}\end{array}$ & $\begin{array}{c}\text { Mass Soil, } \\
\mathrm{g}\end{array}$ & $\begin{array}{c}\text { Mass Leachant, } \\
\mathrm{g}\end{array}$ & Final $\mathrm{pH}$ \\
\hline SJM-Cs-G-1 & 48.00 & 1.00 & 25.01 & not measured \\
\hline SJM-Cs-G-2 & 48.00 & 1.00 & 25.01 & not measured \\
\hline SJM-Cs-G-3 & 48.00 & 1.00 & 25.00 & not measured \\
\hline SJM-Cs-G-4 & 48.00 & 1.00 & 25.00 & not measured \\
\hline SJM-Cs-G-5 & 48.00 & 1.00 & 25.04 & not measured \\
\hline SJM-Cs-G-B1 & 48.00 & - & 25.00 & not measured \\
\hline
\end{tabular}

\begin{tabular}{|c|c|c|c|c|}
\hline Test Number & $\begin{array}{c}\text { Solution Bottle, } \\
\mathrm{g}\end{array}$ & $\begin{array}{c}\text { Bottle }+ \text { test } \\
\text { solution, } \mathrm{g}\end{array}$ & $\begin{array}{c}\text { Bottle }+ \text { test solution } \\
+\mathrm{DIW}+\mathrm{HNO}_{3}, \mathrm{~g}\end{array}$ & Dilution Factor \\
\hline SJM-Cs-G-1 & 11.16 & 33.65 & 33.71 & 1.0027 \\
\hline SJM-Cs-G-2 & 11.16 & 33.92 & 33.97 & 1.0022 \\
\hline SJM-Cs-G-3 & 11.13 & 34.04 & 34.08 & 1.0017 \\
\hline SJM-Cs-G-4 & 11.17 & 23.05 & 23.09 & 1.0034 \\
\hline SJM-Cs-G-5 & 11.15 & 30.61 & 30.65 & 1.0021 \\
\hline SJM-Cs-G-B1 & 11.21 & 27.94 & 27.98 & 1.0024 \\
\hline
\end{tabular}


The mean value of $K_{\mathrm{d}}(\mathrm{Cs})$ is $373 \mathrm{~mL} / \mathrm{g}$ with a standard deviation of $21 \mathrm{~mL} / \mathrm{g}$, giving a relative standard deviation of $5.6 \%$. This is significantly lower than the value $K_{\mathrm{d}}(\mathrm{Cs})=522 \mathrm{~mL} / \mathrm{g}$ measured for Leachant A2 having the slightly higher concentration of $1.35 \times 10^{-4}$ molal $\mathrm{CsCl}$. The mean values of the amounts measured in solution and calculated to be on the soil in the confirmation tests are shown plotted with values measured previously with various leachant concentrations in 2-day tests. The confirmation test results show lower amounts of Cs on the soil than would be predicted based on the concentration in solution. The equation of the regression line is $y=2.78+0.853 x$. For the measured solution concentration of $0.726 \mu \mathrm{g} / \mathrm{mL} \mathrm{Cs}$, a sorbed concentration of $459 \mu \mathrm{g} / \mathrm{g}$ Cs is predicted. This is 1.70 -times the value of $270 \mu \mathrm{g} / \mathrm{g}$ Cs that was determined from the tests. The concentration dependence of $K_{\mathrm{d}}(\mathrm{Cs})$ must be taken into account to determine the precision of the test method. The pooled results of tests conducted with slightly different $\mathrm{CsCl}$ leachant concentrations can be compared to the composition dependence measured in this study (i.e., the results discussed in Section 3.7) to determine the intralaboratory (between-laboratory) precision of the test method by using this approach.

Table 24. Results for replicate tests with Leachant $\mathrm{G}$

\begin{tabular}{|c|c|c|c|c|}
\hline Solution Number & Measured Cs, $\mu \mathrm{g} / \mathrm{L}$ & $\begin{array}{c}\text { Dil.-corrected Cs in } \\
\text { test solution, } \mu \mathrm{g} / \mathrm{L}\end{array}$ & $\begin{array}{c}\text { Leachant Volume, } \\
\mathrm{mL}\end{array}$ & $\begin{array}{c}\text { Mass Cs in } \\
\text { Leachant, } \mu \mathrm{g}\end{array}$ \\
\hline SJM-Cs-G-1 & 727 & 728.94 & 25.01 & 18.23 \\
\hline SJM-Cs-G-2 & 683 & 684.50 & 25.01 & 17.12 \\
\hline SJM-Cs-G-3 & 706 & 707.23 & 25.00 & 17.68 \\
\hline SJM-Cs-G-4 & 715 & 717.41 & 25.00 & 17.94 \\
\hline SJM-Cs-G-5 & 788 & 789.62 & 25.04 & 19.77 \\
\hline SJM-Cs-G-B1 & 17200 & 17241.12 & 25.00 & 18.23 \\
\hline
\end{tabular}

\begin{tabular}{|c|c|c|c|c|}
\hline Test Numbers & $\begin{array}{l}\text { Mass Cs on soil, } \\
\mu \mathrm{g}\end{array}$ & $\mu \mathrm{g}$ Cs/g soil & $\begin{array}{c}\text { Cs in test solution, } \\
\mu \mathrm{g} / \mathrm{mL}\end{array}$ & $\begin{array}{c}K_{\mathrm{d}}(\mathrm{Cs}), \\
\mathrm{mL} / \mathrm{g}\end{array}$ \\
\hline SJM-Cs-G-1 & 270.21 & 270 & 0.729 & 370.69 \\
\hline SJM-Cs-G-2 & 271.32 & 271 & 0.685 & 396.38 \\
\hline SJM-Cs-G-3 & 270.76 & 271 & 0.707 & 382.85 \\
\hline SJM-Cs-G-4 & 270.51 & 271 & 0.717 & 377.06 \\
\hline SJM-Cs-G-5 & 268.67 & 269 & 0.790 & 340.25 \\
\hline \multicolumn{2}{|r|}{ Mean } & 270 & 0.726 & 373.45 \\
\hline \multicolumn{2}{|c|}{ Standard Deviation } & - & 0.0394 & 20.84 \\
\hline \multicolumn{2}{|c|}{ Relative Standard Deviation } & - & $5.43 \%$ & $5.58 \%$ \\
\hline
\end{tabular}

\section{Supplemental Effect of Scale Tests}

A series of six tests were conducted to measure the effect of the test scale (i.e., the amounts of soil and solution) over a wider range than was addressed in previous tests (see Section 3.4). The approximately $330 \mathrm{~g}$ of Leachant $\mathrm{G}$ that remained after conducting the supplemental replicate tests was diluted with about $80 \mathrm{~g}$ of demineralized water to provide enough leachant to conduct the series of effect of scale tests. The resulting solution is referred to as Leachant $\mathrm{H}$. The series of tests is summarized in Table 25. The analytical results and calculated values are provided in Table 26. The Cs concentration in the blank test with Leachant $\mathrm{H}$ was measured to be $14635 \mathrm{~g} / \mathrm{L}$, which is $7.85 \times 10^{-5}$ molal $\mathrm{CsCl}$. This value was used to calculate the sorbed mass and $K_{\mathrm{d}}(\mathrm{Cs})$ value for each test. The results are summarized in Table 26 and plotted in Figure 16. The values of $K_{\mathrm{d}}(\mathrm{Cs})$ show a slight increase with the amount of soil, but this is well within the uncertainty of each value (which is about $15 \%$ ). The mean value of $K_{\mathrm{d}}(\mathrm{Cs}$ ) is $695 \mathrm{~mL} / \mathrm{g}$ and 


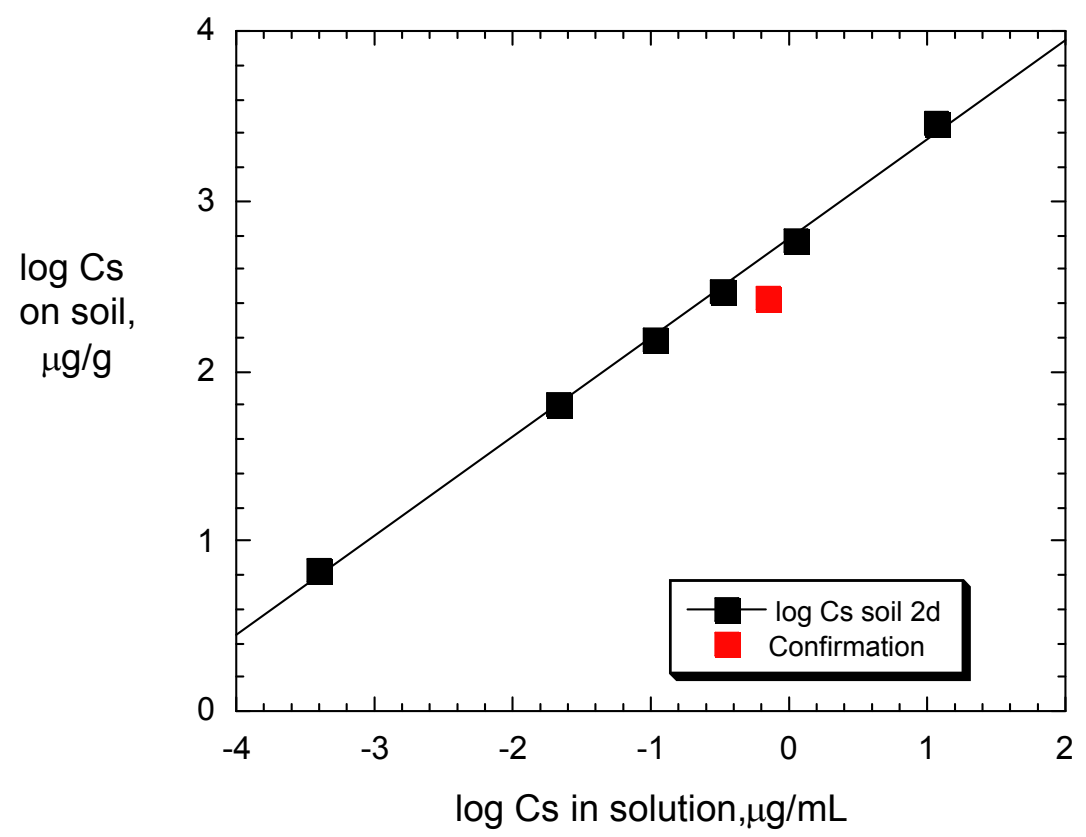

Figure 15. Comparison of confirmation tests result with measured composition dependence of $K_{\mathrm{d}}(\mathrm{Cs})$.

the standard deviation is $17 \mathrm{~mL} / \mathrm{g}$. The higher $K_{\mathrm{d}}(\mathrm{Cs})$ value measured with Leachant $\mathrm{H}$ compared to that measured with Leachant $\mathrm{G}$ is attributed to the lower Na concentration in Leachant $\mathrm{H}$, which competes with Cs for sorption sites. The Na concentration in Leachant $\mathrm{H}$ is lower because Leachant $\mathrm{G}$ was diluted with demineralized water rather than the silicate solution that was used to make the other leachants.

Table 25. Data for tests conducted with Leachant $\mathrm{H}$ and different amounts of soil and solution

\begin{tabular}{|c|c|c|c|c|c|}
\hline Test Number & $\begin{array}{c}\text { Duration, } \\
\mathrm{h}\end{array}$ & $\begin{array}{c}\text { Mass Soil, } \\
\mathrm{g}\end{array}$ & $\begin{array}{c}\text { Mass } \\
\text { Leachant, } \mathrm{g}\end{array}$ & $\begin{array}{c}\text { Soil/Leachant } \\
\text { mass ratio }\end{array}$ & Final $\mathrm{pH}$ \\
\hline SJM-Cs-H-1 & 47.22 & 0.50 & 12.52 & 25.04 & not measured \\
\hline SJM-Cs-H-2 & 47.22 & 1.00 & 25.00 & 25.00 & not measured \\
\hline SJM-Cs-H-3 & 47.22 & 2.00 & 51.99 & 26.00 & not measured \\
\hline SJM-Cs-H-4 & 47.22 & 3.00 & 75.00 & 25.00 & not measured \\
\hline SJM-Cs-H-5 & 47.22 & 4.01 & 100.23 & 25.00 & not measured \\
\hline SJM-Cs-H-6 & 47.22 & 5.00 & 125.00 & 25.00 & not measured \\
\hline
\end{tabular}

\begin{tabular}{|c|c|c|c|c|}
\hline Test Number & $\begin{array}{c}\text { Solution Bottle, } \\
\mathrm{g}\end{array}$ & $\begin{array}{c}\text { Bottle }+\mathrm{Cs} \\
\text { solution, } \mathrm{g}\end{array}$ & $\begin{array}{c}\text { Bottle + Cs solution } \\
+\mathrm{DIW}+\mathrm{HNO}_{3}, \mathrm{~g}\end{array}$ & Cs Dilution Factor \\
\hline SJM-Cs-H-1 & 11.2 & 22.09 & 22.14 & 1.0046 \\
\hline SJM-Cs-H-2 & 11.17 & 30.04 & 30.09 & 1.0026 \\
\hline SJM-Cs-H-3 & 11.17 & 23.79 & 23.84 & 1.0040 \\
\hline SJM-Cs-H-4 & 11.16 & 25.36 & 25.41 & 1.0035 \\
\hline SJM-Cs-H-5 & 11.18 & 27.06 & 27.11 & 1.0031 \\
\hline SJM-Cs-H-6 & 11.17 & 25.94 & 25.97 & 1.0020 \\
\hline Leachant H & 11.15 & 32.27 & 32.32 & 1.0024 \\
\hline
\end{tabular}


Table 26. Results for tests conducted with Leachant $\mathrm{H}$ and different amounts of soil and solution

\begin{tabular}{|c|c|c|c|}
\hline Test Number & $\begin{array}{c}\text { Measured Cs, } \\
\mu \mathrm{g} / \mathrm{L}\end{array}$ & $\begin{array}{c}\text { Dil.-corrected Cs in } \\
\text { test solution, } \mu \mathrm{g} / \mathrm{L}\end{array}$ & $\begin{array}{c}\text { Mass Cs in test } \\
\text { solution, } \mu \mathrm{g}\end{array}$ \\
\hline SJM-Cs-H-1 & 518 & 520.4 & 6.52 \\
\hline SJM-Cs-H-2 & 522 & 523.4 & 13.08 \\
\hline SJM-Cs-H-3 & 525 & 527.1 & 27.40 \\
\hline SJM-Cs-H-4 & 505 & 506.8 & 38.01 \\
\hline SJM-Cs-H-5 & 489 & 490.5 & 49.17 \\
\hline SJM-Cs-H-6 & 501 & 502.0 & 62.75 \\
\hline Leachant H & 14600 & 14635 & - \\
\hline
\end{tabular}

\begin{tabular}{|c|c|c|c|c|c|}
\hline Test Number & $\begin{array}{c}\text { Leachant } \\
\text { Volume, } \mathrm{mL}\end{array}$ & $\begin{array}{c}\text { Mass Cs in } \\
\text { Leachant, } \mu \mathrm{g}\end{array}$ & $\begin{array}{c}\text { Mass Cs on } \\
\text { soil, } \mu \mathrm{g}\end{array}$ & $\mu \mathrm{g}$ Cs/g soil & $\begin{array}{c}K_{\mathrm{d}}(\mathrm{Cs}) \\
\mathrm{mL} / \mathrm{g}\end{array}$ \\
\hline SJM-Cs-H-1 & 12.52 & 183.22 & 176.71 & 353.42 & 679.16 \\
\hline SJM-Cs-H-2 & 25.00 & 365.86 & 352.78 & 352.78 & 674.04 \\
\hline SJM-Cs-H-3 & 51.99 & 760.85 & 733.45 & 366.72 & 695.77 \\
\hline SJM-Cs-H-4 & 75.00 & 1097.59 & 1059.58 & 353.19 & 696.94 \\
\hline SJM-Cs-H-5 & 100.23 & 1466.82 & 1417.66 & 353.53 & 720.70 \\
\hline SJM-Cs-H-6 & 125.00 & 1829.32 & 1766.57 & 353.31 & 703.79 \\
\hline
\end{tabular}

The horizontal dashed lines in Figure 16 are drawn at the overall average values. The $K_{\mathrm{d}}(\mathrm{Cs})$ values show a slight upward trend (as opposed to the slight downward trend seen in Figure 5) that is well within the estimated $15 \%$ experimental uncertainty in determining the value of $K_{\mathrm{d}}(\mathrm{Cs})$.

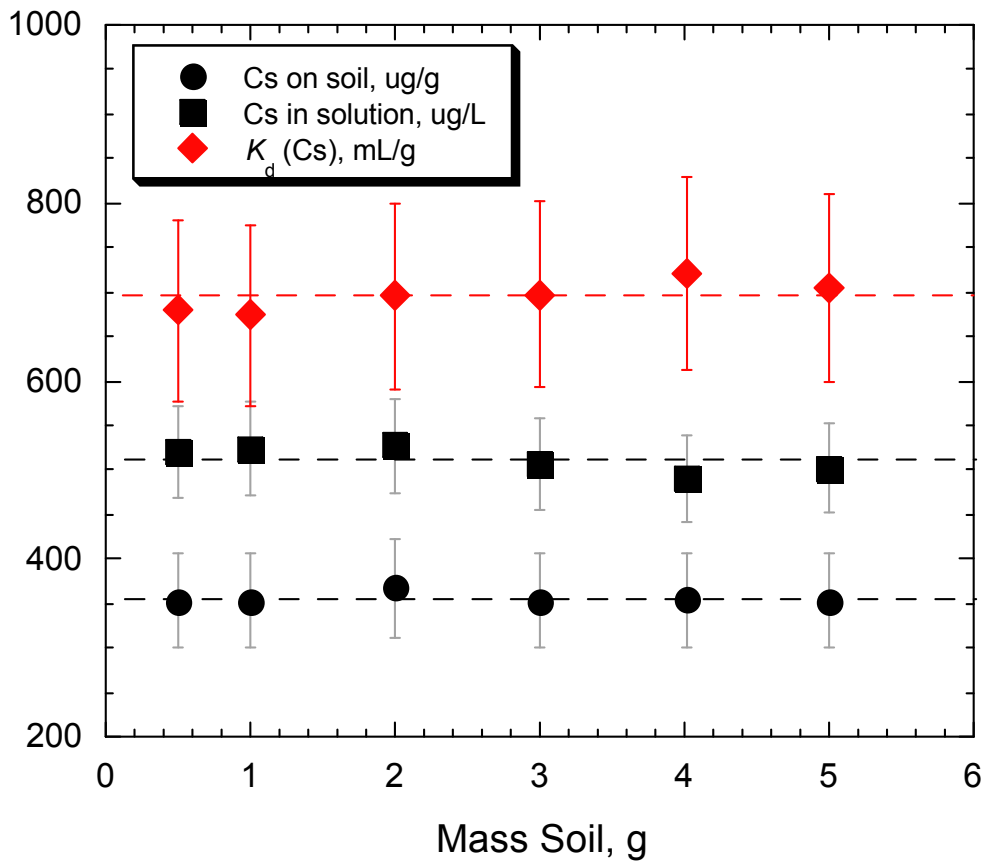

Figure 16. Results of effect of scale tests conducted with Leachant $\mathrm{H}$. 


\section{SUMMARY AND RECOMMENDATIONS}

Tests were conducted to measure the uptake of $\mathrm{Cs}$ and $\mathrm{Sr}$ dissolved as $\mathrm{CsCl}$ and $\mathrm{Sr}\left(\mathrm{NO}_{3}\right)_{2}$ in a dilute $\mathrm{NaHCO}_{3} / \mathrm{SiO}_{2}$ solution (representing contaminants in a silicate groundwater) by a NIST standard reference material of San Joaquin soil (SRM 2709a). Tests were run to measure the repeatability of the method and the sensitivity of the test response to the reaction time, the mass of soil used (at a constant soil-to-solution ratio), the solution $\mathrm{pH}$, and the contaminant concentration. All tests were conducted in screw-top Teflon vessels at $30^{\circ} \mathrm{C}$ in an oven. All solutions were passed through a 0.45 -m pore size cellulose acetate membrane filter and stabilized with nitric acid prior to analysis with inductively-coupled plasma mass spectrometry (ICP-MS). Scoping tests with soil in demineralized water resulted in a solution $\mathrm{pH}$ of about 8.0 and the release of small amounts of $\mathrm{Sr}$ from the soil. Solutions were made with targeted concentrations of $1 \times 10^{-6} \underline{\mathrm{m}}, 1 \times 10^{-5} \underline{\mathrm{m}}, 2.5 \times 10^{-5} \underline{\mathrm{m}}, 5 \times 10^{-5} \underline{\mathrm{m}}, 1 \times 10^{-4} \underline{\mathrm{m}}$, and $5 \times 10^{-4} \underline{\mathrm{m}}$. (The actual Cs concentrations were about 50\% higher and the actual Sr concentrations about 30\% lower than these targeted values.) The $\mathrm{pH}$ values of all solutions were adjusted to about $\mathrm{pH} 8.5$ so that the effects of $\mathrm{pH}$ and concentration could be measured separately. The nominal $1 \times 10^{-4} \underline{\mathrm{m}}$ solutions were used to measure the repeatability and the effects of duration, scale, and imposed $\mathrm{pH}$.

\subsection{Testing Results}

\section{Repeatability}

Replicate tests run to measure the intra-laboratory precision of the method using the $1.5 \times 10^{-4} \mathrm{~m} \mathrm{Cs}$ solution resulted in a mean value of $K_{\mathrm{d}}(\mathrm{Cs})=522 \mathrm{~mL} / \mathrm{g}$, standard deviation of $16 \mathrm{~mL} / \mathrm{g}$, and relative standard deviation of about $3.1 \%$ in $K_{\mathrm{d}}(\mathrm{Cs})$ for the pooled results of 1 and 2-day tests. Replicate tests using the $0.7 \times 10^{-4} \underline{\mathrm{m}} \mathrm{Sr}$ solution resulted in a mean value of $K_{\mathrm{d}}(\mathrm{Sr})=162 \mathrm{~mL} / \mathrm{g}$, standard deviation of $8 \mathrm{~mL} / \mathrm{g}$, and relative standard deviation of $5 \%$ in $K_{\mathrm{d}}(\mathrm{Sr})$ for 1-day tests. The uncertainty in the calculated value of $K_{\mathrm{d}}$ was determined by propagation of errors method to be about $15 \%$ due primarily to uncertainty in the measured concentration of the test solution. The repeatability of the test under the conditions used in this study (the intra-laboratory precision) is well within the uncertainty of the individual $K_{\mathrm{d}}(\mathrm{Cs})$ values.

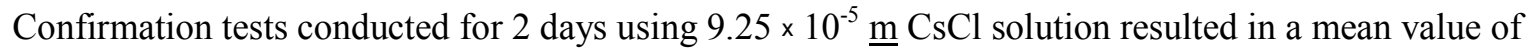
$K_{\mathrm{d}}(\mathrm{Cs})=373 \mathrm{~mL} / \mathrm{g}$, standard deviation of $21 \mathrm{~mL} / \mathrm{g}$, and relative standard deviation of $5.6 \%$.

\section{Effect of Scale}

Values of $K_{\mathrm{d}}(\mathrm{Cs})$ in 1-day tests conducted using the $1.5 \times 10^{-4} \mathrm{~m} \mathrm{CsCl}$ solution with $0.2,0.5,1.0$, and $1.5 \mathrm{~g}$ soil with solution masses of 25 -times the soil mass showed a small negative correlation outside the uncertainty due to the repeatability of the tests, but within the uncertainties of the individual tests.

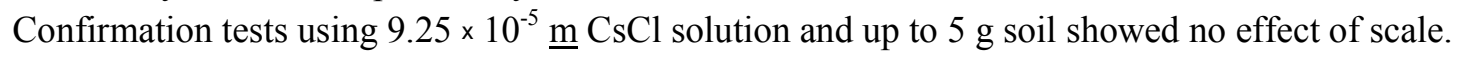

\section{Effect of Duration}

Steady-state concentrations were attained within about 1 hour (the shortest test duration was about 15 minutes) in tests conducted with $0.5 \mathrm{~g}$ soil in either $12.5 \mathrm{~g}$ of the $1.5 \times 10^{-4} \underline{\mathrm{m}}$ Cs solution or $12.5 \mathrm{~g}$ of the $0.7 \times 10^{-4} \underline{\mathrm{m}}$ Sr solution and persisted through the longest test duration, which was about 7 days. The rapid uptakes of Cs and $\mathrm{Sr}$ measured in these tests are consistent with the uptakes measured for $\mathrm{Cs}$ and $\mathrm{Sr}$ on similar soilds; for example Cs on humic acid (Celebi et al. 2009), Cs on various clays (Bayulken et al. 2010), Cs on soil (Setiawan 2007), Cs on clay (Ugur and Turhan, 2001), Cs and Sr on Zeolite A (elRahman, et al. 2006), Sr on uranium antimontate (Kumar and Sudarsan, 2007), and Sr on synthetic muscovite (Sharma and Shirvastava 2010). 


\section{Effect of Imposed pH}

The sorption of cesium in 1- and 2-day tests with the $1.5 \times 10^{-4} \mathrm{~m}$ Cs solution was independent of the imposed $\mathrm{pH}$ within the range $\mathrm{pH} 7.5-\mathrm{pH} 9.5$, whereas the uptake of strontium from the $1.5 \times 10^{-4} \mathrm{~m} \mathrm{Sr}$ solution increased exponentially over this range. The solution $\mathrm{pH}$ drifted to near the "equilibrium" $\mathrm{pH}$ of the soil/solution system under these test conditions (i.e., temperature and relative masses of soil and water) in all tests. The use of a $\mathrm{pH}$ buffer was avoided to eliminate possible complexation and competitive sorption. Previous tests have shown the value of $K_{\mathrm{d}}(\mathrm{Cs})$ to increase with $\mathrm{pH}$ over the range pH 3 to $\mathrm{pH} 8$ (Bayülken et al. 2010) but to decrease between $\mathrm{pH} 8$ and $\mathrm{pH} 10$ (Giannakopoulou et al. 2007). Values of $K_{\mathrm{d}}(\mathrm{Ba})$ on humic acid was seen to increase between $\mathrm{pH} 2$ and $\mathrm{pH} 4$, remain nearly constant between $\mathrm{pH} 4$ and $\mathrm{pH} 8$, and then decrease between $\mathrm{pH} 8$ and $\mathrm{pH} 10$ (Celebi et al. 2009). elRahman et al. (2008) found the sorption of Cs and Sr onto Zeolite A increased with $\mathrm{pH}$ from $\mathrm{pH} 2$ to $\mathrm{pH}$ 8. Westrich et al. (2000) showed the uptake of $\mathrm{Sr}$ by quartz and goethite increased from near $0 \%$ to $80 \%$ between $\mathrm{pH} 4$ and $\mathrm{pH} 10$ and was well-described using a 1-site model, but the uptake on smectite remained between $60 \%$ and $80 \%$ over this range and was better fit with a 2 -site model.

\section{Effect of Concentration}

Tests were conducted for about 1,2 , and 3 days with $0.5 \mathrm{~g}$ soil and $12.5 \mathrm{~g}$ of each solution concentration. The Cs results were well-fitted with a Freundlich isotherm model with $K_{\mathrm{F}}(\mathrm{Cs})=646 \mathrm{~mL} / \mathrm{g}$ and $n=0.568$ (for the 3-day tests). The $\mathrm{Sr}$ uptake followed a linear isotherm with $K_{\mathrm{d}}(\mathrm{Sr})=394$ (for the 3-day tests), except at the highest $\mathrm{Sr}$ concentration, which was significantly lower than that predicted and may indicate that the soil was saturated with $\mathrm{Sr}$. The values of both $K_{\mathrm{F}}(\mathrm{Cs})$ and $K_{\mathrm{d}}(\mathrm{Sr})$ increased slightly with the test duration, suggesting that steady state was not attained within one day at the high solution concentrations. Langmuir isotherms adequately described the results of tests at the highest concentration, but the results at low concentrations were not fit well.

The data of Celebi et al. (2009) and Bayulken et al. (2010) for Cs sorption on humic acid and clay, respectively, were fitted well with Freundlich isotherms. Tests conducted by Uğur and Turhan (2011) to measure the sorption of Cs on different size fractions of clay were well fit with Langmuir isotherms.

\subsection{Recommended Conditions for an ASTM C1733 Reference Test}

The focus of the study described in the report was to (1) evaluate the inherent uncertainty associated with performing the ASTM C1733 standard batch test to generate data used to calculate $K_{\mathrm{d}}$ values and (2) recommend a reference test material, test solution, and test conditions that can be used to establish a test response and precision that can be used to gauge the success of tests conducted by new users and separate the uncertainty from test performance from real effects of test conditions (i.e., other solids, solutions, and testing parameters). The precision of conducting the ASTM C1733 test and the dependencies on test variables that have been evaluated are believed to represent the least-biased conditions. Confounding factors that were not considered in this analysis include contributions to the uncertainty from the day-today variance in the analytical measurements (since solutions from groups of tests were analyzed as a single set), test performance by different operators, size and specific surface area the use of a finely divided and compositionally homogeneous NIST standard soil, ionic strength and competitive sorption. Many of these factors will be taken into account in measures of the inter-laboratory precision, while other issues are topics for research studies for effects beyond test execution.

The following provide recommendations for test materials and test conditions that can be used as a reference test to directly compare results of tests conducted at different laboratories to verify tests and 
analyses are conducted properly. They are also recommended for use in inter-laboratory studies to measure the reproducibility of the test method and establish test values suitable for direct comparisons.

\section{Reference Soil}

The NIST SRM 2709a San Joaquin soil is a suitable standard material for direct use as a sorbent for determining the bias of procedure ASTM C1733. The as-received dried soil can be used in testing without further preparation (washing or sizing). A large amount of soil is available from NIST and accessible to researchers world-wide in 50-g allotments. The composition of the soil is well-characterized and its physical characteristics acceptably uniform. However, it is recommended that a single source be used by participants in inter-laboratory studies to mitigate the effects of any differences between allotments, which could be a mixture of soil from more than one 50-g jar of SRM 2709a.

\section{Reference Solution}

The use of $\mathrm{CsCl}$ dissolved in a dilute $\mathrm{NaHCO}_{3} / \mathrm{SiO}_{2}$ matrix solution is appropriate for measuring experimental bias and testing precision. The matrix solution is prepared following the recipe provided in ASTM C1220 step 7.4, which includes adjustment to $\mathrm{pH}$ 8.0. It is recommended that the $\mathrm{pH}$ be adjusted to $\mathrm{pH} 8.5$ (see Reference $\mathrm{pH}$ below) after the addition of $\mathrm{CsCl}$ and that each solution concentration be adjusted separately. The range of concentrations used in the present study is adequate for studying the concentration dependences and evaluating isotherms. The solutions appear to be stable over time and Cs is not released from the San Joaquin soil to a significant extent. The uptake of Cs occurs rapidly and appears to follow a relatively simple mechanism that displays Freundlich behavior over a fairly wide compositional range. A solution composition of $1.5 \times 10^{-4} \mathrm{~m} \mathrm{CsCl}(0.0253 \mathrm{~g} \mathrm{CsCl} / \mathrm{kg}$ solution $)$ is recommended for use in tests to measure the repeatability and reproducibility of the $\mathrm{C} 1733$ method.

\section{Reference Imposed pH}

It is recommended that the solutions be adjusted to $\mathrm{pH} 8.5$ when they are prepared. The matrix solution that is prepared following the recipe provided in ASTM C1220 step 7.4 includes an adjustment to pH 8.0. The present tests were conducted with solutions that had been adjusted to $\mathrm{pH} 8.5$ to be slightly higher than the $\mathrm{pH}$ that was attained in soil blank tests. It is recommended that both the matrix solution and the Cs solutions be adjusted to $\mathrm{pH} 8.5$ to mitigate $\mathrm{pH}$ drift during the test. The uptake of Cs was measured to be fairly insensitive to the $\mathrm{pH}$ over the range $\mathrm{pH} 8.0-9.1$, so the effect of a small $\mathrm{pH}$ drift on the test results will be minor.

\section{Reference Soil and Solution Mass}

A sample size of $1 \mathrm{~g}$ dry soil and $25 \mathrm{~g}$ solution is recommended for reference tests. The use of between 1 and $5 \mathrm{~g}$ of soil is recommended in the ASTM C1733 method. The logical reason for this is need for small samples to provide a uniform and reproducible phase assemblage (and relative surface areas) that represents the environment of interest. The present tests show SRM 2709a soil is sufficiently uniform that less than $1 \mathrm{~g}$ can be used in scoping tests and when limited amounts of soil are available. For the present tests, $0.5-\mathrm{g}$ sample sizes were used in order to conduct as many tests as possible using the $100 \mathrm{-g}$ of soil that was available. The use of $12.5 \mathrm{~mL}$ solution in these provides ample solution for analysis without excessive waste, which could be an issue when using hazardous soils or groundwaters.

Nevertheless, a sample size of $1 \mathrm{~g}$ is recommended for inter-laboratory tests conducted to measure the test precision and reproducibility to be consistent with the range of soil mass called for in the procedure. 


\section{Reference Test Duration}

A 2-day test duration is recommended for reference tests. Although 1-day tests were adequate to quantify the intra-laboratory precision and effects of test variables, a 2-day during will reduce the impact of uncontrolled testing variables, such as the exact time the system is at temperature. The present tests suggest that kinetic effects may have contributed small differences to the measured effects of $\mathrm{pH}$ and contaminant concentration, albeit within the experimental uncertainty.

\section{Reference Temperature}

A temperature of $30^{\circ} \mathrm{C}$ is recommended for reference tests. Although all tests in this study were conducted at $30^{\circ} \mathrm{C}$ and the sensitivity of the test response to temperature was not evaluated, this temperature is easily attainable in the laboratory using an incubator or low-temperature oven and avoids the variance and fluctuations of ambient temperatures common to most laboratories. While temperatures below ambient laboratory temperatures are more representative of subaerial conditions (e.g., $20^{\circ} \mathrm{C}$ ), refrigeration units are less-common in laboratories and the value of is not expected to be significantly different over a $\sim 20^{\circ} \mathrm{C}$ temperature range near ambient.

\section{Replicate Tests}

It is recommended that at least five replicate tests be conducted to measure the intra-laboratory precision (repeatability) at each laboratory and to provide data for determining the inter-laboratory precision (reproducibility). The tests should be conducted by a single operator and analyzed as a set using the same instrument calibration. Although it was not done in the present study, a sample of the leachant solution should be analyzed together with the test solutions to eliminate any contribution of the day-to-day analytical variance of solution analysis. Note that the $K_{\mathrm{d}}(\mathrm{Cs})$ values from tests conducted in this study are not suitable for use in inter-laboratory comparisons because the test solutions from test conducted for 1 and 2 days were combined (inadvertently) for analysis and added uncertainty to the results, despite the finding that test duration beyond 1 day did not significantly contribute to the variance. It is expected that small differences in the leachant Cs concentration will provide the most variance in an inter-laboratory study. This is supported by the results of confirmation replicate tests conducted with a less concentrated $\mathrm{CsCl}$ solution. It is expected that the effect of $\mathrm{CsCl}$ concentration on the value of $K_{\mathrm{d}}(\mathrm{Cs})$ measured in this study can be used to distinguish between the effects of concentration and test precision in an interlaboratory study. 


\section{REFERENCES}

American Society of Testing and Materials. (2010). Standard Test Method for Distribution Coefficients of Inorganic Species by the Batch Method [C1733]. Annual Book of ASTM Standards, Vol. 12.01, ASTM-International, West Conshohocken, PA.

Bayülken, S., Başçetin, E., Güçlü, K., and Apak, R. (2010). "Investigation and Modeling of Cesium (I) Adsorption by Turkish Clays: Bentonite, Zeolite, Sepiolite, and Kaolinite.” Environmental Progress \& Sustainable Energy, 30(1), 70-80.

Celebi, O., Kilikli, A., and Erten, H. N. (2009). "Sorption of Radioactive Cesium and Barium Ions onto Solid Humic Acid.” Journal of Hazardous Materials, 168, 695-703.

El-Rahman, K. A., El-Sourougy, M., Abdel-Monem, N., and Ismail, I. (2006). "Modeling the Sorption Kinetics of Cesium and Strontium Ions on Zeolite A." Journal of Nuclear and Radiochemical Sciences, $7(2), 21-27$.

EPA (1999a). Understanding Variation in Partition Coefficient, $K_{d}$ Values: Volume I. The $K_{d}$ Model, Methods of Measurement, and Application of Chemical Reaction Codes. U.S. Environmental Protection Agency Report EPA 402-R-99-004A.

EPA (1999b). Understanding Variation in Partition Coefficient, $K_{d}$ Values: Volume II. Review of Geochemistry and Available Kd Values for Cadmium, Cesium, Chromium, Lead, Plutonium, Radon, Strontium, Thorium, Tritium (3H), and Uranium. U.S. Environmental Protection Agency Report EPA 402-R-99-004B.

EPA (2004). Understanding Variation in Partition Coefficient, $K_{d}$ Values: Volume III. Review of Geochemistry and Available Kd Values for Americium, Arsenic, Currium, Iodine, Neptunium, Radium, and Technetium. U.S. Environmental Protection Agency Report EPA 402-R-04-002C.

Giannakopoulou, F., Haidouti, C., Chronopoulou, A., and Gasparatos, D. (2007). "Sorption Behavior of Cesium on Various Soils Under Different pH Levels." Journal of Hazardous Materials, 149, 553-556.

Kumar, S. S. and Sudarsan, K. G. (2007). "Adsorption of Strontium from Acidic Solutions Using an Inorganic Echanger-Uranium Antimonate.” Acta Chimica Slovenica, 56, 480-483.

National Institute of Standards \& Technology. (2009). Standard Reference Material 2709a: San Joaquin Soil. Certificate of Analysis available at www.nist.gov .

Setiawan, B. (2007). "Effect of Ca Ions in Solution to Cs-137 Sorption into Soil Samples. Journal of Waste Management Technology, 10(2), 32-35.

Sharma, P. and Shrivastava, A. (2010). "Sorption and Desorption of Eu(III), Sr(II), and Sm(II) on the Synthetic Analogue of Muscovite." Journal of Advanced Engineering \& Application, 212-219.

Uğur, F. A. and Turhan, S. (2001). "Experimental Investigation of Radiocesium Sorption on Ceramic Clay using a Batch Method.” Journal of Radioanalytical and Nuclear Chemistry, 288, 347-350.

Westrich, H. R., Anderson, H. L., Arthur, S. E., Brady, P. V., Cygan, R. T., Liang, J. J., \& Zhang, P. C. (2000). Prediction of Metal Sorption in Soils, Sandia National Laboratories Report SAND2000-0585C.

Yu, C., Orlandini, K. A., Cheng, J. J., \& Biwer, B. M. (2001). Assessing the Impact of Hazardous Constituents on the Mobilization, Transport, and Fate of Radionuclides in RCRA Waste Disposal Units, Argonne National Laboratory Report ANL/EAD/TM-93. 


\section{Appendix A: Chemical Composition of SRM 2709a}

The compositions provided in the NIST Certificate of Analysis for SRM 2709a (NIST 2011) are provided below. The certified values in Table 1 represent the means from analyses using one, two, or three methods conducted at NIST and/or the US Geological Society (Denver, CO) and the expanded uncertainties. The reference values in Table 2 (with uncertainties) and informational values Table 3 (without uncertainties) represent the results of single method analyses performed at NIST.

Table 1. Certified Values ${ }^{(a)}$ (Dry-Mass Basis) for Selected Elements in SRM 2709a

Element

Aluminum

Calcium

Iron

Magnesium

Phosphorus

Potassium

Silicon

Sodium

Titanium
Mass Fraction

(\%)

$\begin{array}{lll}7.37 & \pm & 0.16 \\ 1.91 & \pm & 0.09 \\ 3.36 & \pm & 0.07 \\ 1.46 & \pm & 0.02 \\ 0.0688 & \pm & 0.0013 \\ 2.11 & \pm & 0.06 \\ 30.3 & \pm & 0.4 \\ 1.22 & \pm & 0.03 \\ 0.336 & \pm & 0.007\end{array}$

Element

Antimony

Barium

Cadmium

Chromium

Cobalt

Lead

Manganese

Strontium

Vanadium

Zirconium
Mass Fraction

( $\mathrm{mg} / \mathrm{kg}$ )

$\begin{array}{ccc}1.55 & \pm & 0.06 \\ 979 & \pm & 28 \\ 0.371 & \pm & 0.002 \\ 130 & \pm & 9 \\ 12.8 & \pm & 0.2 \\ 17.3 & \pm & 0.1 \\ 529 & \pm & 18 \\ 239 & \pm & 6 \\ 110 & \pm & 11 \\ 195 & \pm 46\end{array}$

Table 2. Reference Values ${ }^{(a)}$ (Dry-Mass Basis) for Selected Elements in SRM 2709a

Element

Arsenic

Cerium

Cesium

Copper

Europium

Gadolinium

Lanthanum

Mercury ${ }^{(b)}$

Nickel

Rubidium

Scandium

Thallium

Thorium

Uranium

Zinc

\section{Mass Fraction \\ $(\mathrm{mg} / \mathrm{kg})$}

\begin{tabular}{|c|c|c|}
\hline 10.5 & + & 0.3 \\
\hline 42 & + & 1 \\
\hline 5.0 & \pm & 0.1 \\
\hline $33.9=$ & & 0.5 \\
\hline 0.83 & \pm & 0.02 \\
\hline 3.0 & & 0.1 \\
\hline 21.7 & & 0.4 \\
\hline 0.9 & \pm & 0.2 \\
\hline $85=$ & & 2 \\
\hline 99 & & 3 \\
\hline $11.1=$ & & 0.1 \\
\hline $0.58=$ & & 0.01 \\
\hline $10.9=$ & & 0.2 \\
\hline 3.15 & & 0.05 \\
\hline & & \\
\hline
\end{tabular}


Table 3. Information Values ${ }^{(2)}$ (Dry Mass Basis) for Selected Elements in SRM 2709a

$\begin{array}{lc}\text { Element } & \begin{array}{c}\text { Mass Fraction } \\ (\mathrm{mg} / \mathrm{kg})\end{array} \\ \text { Boron } & 74 \\ \text { Dysprosium } & 3 \\ \text { Hafnium } & 4 \\ \text { Lutetium } & 0.3 \\ \text { Neodymium } & 17 \\ \text { Samarium } & 4 \\ \text { Selenium } & 1.5 \\ \text { Tantalum } & 0.7 \\ \text { Terbium } & 0.5 \\ \text { Ytterbium } & 2\end{array}$




\section{Appendix B: Calculations}

\section{B.1 Preparation of synthetic silicate groundwater (SSG)}

Bottle 1 tare $=184.40 \mathrm{~g}$

Bottle $1+0.1971 \mathrm{~g} \mathrm{SiO}_{2} \cdot 2 \mathrm{H}_{2} \mathrm{O}+0.3577 \mathrm{~g} \mathrm{NaHCO}_{3}+\mathrm{DIW}=1184.42 \mathrm{~g}$

1000.02 g solution

Initial $\mathrm{pH} 9.21$. Adjusted to $\mathrm{pH} 8.99$ by adding dilute $\mathrm{HNO}_{3}$

Bottle 2 tare $=182.17 \mathrm{~g}$

Bottle $2+0.1920 \mathrm{~g} \mathrm{SiO}_{2} \cdot 2 \mathrm{H}_{2} \mathrm{O}+0.3585 \mathrm{~g} \mathrm{NaHCO}_{3}+\mathrm{DIW}=1182.16 \mathrm{~g}$

$999.99 \mathrm{~g}$ solution

Initial $\mathrm{pH}$ 9.28. Adjusted to $\mathrm{pH} 8.98$ by adding dilute $\mathrm{HNO}_{3}$.

\section{B.2 Preparation of Cs and Sr solutions}

Formula weight: $\mathrm{CsCl}=168.36 \mathrm{~g} / \mathrm{mole}$

$\mathrm{CsCl}$ stock bottle $1: \frac{0.3367 \mathrm{~g} \mathrm{CsCl}}{100.00 \mathrm{~g} \text { solution }} \frac{1 \mathrm{~mole}}{168.36 \mathrm{~g} \mathrm{CsCl}} \frac{1000 \mathrm{~g}}{1 \mathrm{~kg}}=0.0200$ molal

$\mathrm{CsCl}$ stock bottle 2: $\frac{0.3351 \mathrm{~g} \mathrm{CsCl}}{100.00 \mathrm{~g} \text { solution }} \frac{1 \mathrm{~mole}}{168.36 \mathrm{~g} \mathrm{CsCl}} \frac{1000 \mathrm{~g}}{1 \mathrm{~kg}}=0.0199$ molal

Formula weight: $\operatorname{Sr}\left(\mathrm{NO}_{3}\right)_{2}=211.63 \mathrm{~g} / \mathrm{mole}$

$\operatorname{Sr}\left(\mathrm{NO}_{3}\right)_{2}$ stock bottle 1: $\frac{0.4233 \mathrm{~g} \mathrm{Sr}\left(\mathrm{NO}_{3}\right)_{2}}{100.00 \mathrm{~g} \text { solution }} \frac{1 \text { mole }}{211.63 \mathrm{~g} \mathrm{Sr}\left(\mathrm{NO}_{3}\right)_{2}} \frac{1000 \mathrm{~g}}{1 \mathrm{~kg}}=0.0200$ molal

$\mathrm{Sr}\left(\mathrm{NO}_{3}\right)_{2}$ stock bottle 2: $\frac{0.4279 \mathrm{~g} \mathrm{Sr}\left(\mathrm{NO}_{3}\right)_{2}}{100.00 \mathrm{~g} \text { solution }} \frac{1 \text { mole }}{211.63 \mathrm{~g} \mathrm{Sr}\left(\mathrm{NO}_{3}\right)_{2}} \frac{1000 \mathrm{~g}}{1 \mathrm{~kg}}=0.0202$ molal

\section{B.3 Densities of $\mathrm{Cs}$ and $\mathrm{Sr}$ solutions}

Volume of volumetric flask:

Mass empty flask: $56.17 \mathrm{~g}$;

Mass flask + DIW: $155.19 \mathrm{~g}$;

Mass DIW $=155.37-56.17=99.20 \mathrm{~g}$

Density of water at $30{ }^{\circ} \mathrm{C}=0.99565 \mathrm{~g} / \mathrm{mL}$;

Volume volumetric flask $=\frac{99.20 \mathrm{~g}}{0.99565 \mathrm{~g} / \mathrm{mL}}=9.963 \mathrm{~mL}$.

Mass empty flask: $56.18 \mathrm{~g}$;

Mass flask $+1.5 \times 10^{-4} \underline{\mathrm{m}} \mathrm{CsCl}$ solution $=155.28 \mathrm{~g}$;

Mass Cs solution $=155.28-56.17=99.09 \mathrm{~g}$. 
Density CsCl solution $=\frac{99.09 \mathrm{~g}}{9.963 \mathrm{~mL}}=0.9946 \mathrm{~g} / \mathrm{mL}$.

Mass empty flask: $55.99 \mathrm{~g}$;

Mass flask $+0.7 \times 10^{-4} \underline{\mathrm{m}} \mathrm{Sr}\left(\mathrm{NO}_{3}\right)_{2}$ solution $=155.28 \mathrm{~g}$;

Mass $\mathrm{Sr}$ solution $=155.28-55.99=99.29 \mathrm{~g}$.

Density $\mathrm{Sr}\left(\mathrm{NO}_{3}\right)_{2}$ solution $=\frac{99.29 \mathrm{~g}}{9.963 \mathrm{~mL}}=0.9966 \mathrm{~g} / \mathrm{mL}$.

\section{B.4 Bragg's law calculation of d-spacing}

Bragg's law (Equation 6) was rearranged to solve for $d$ as

$$
d=\frac{\lambda}{2 \sin (2 \theta / 2)}
$$

The $2 \theta$ values of the peaks were determined by inspection of the spectrum and the digitized file provided by the instrument. The value of $2 \theta$ was converted from degrees to radians by multiplying the value in degrees by $\mathrm{pi} / 180(\mathrm{pi}=3.14159)$. The $d$-spacing was then calculated for $\lambda=1.5406 \AA$. For example, the most intense peak in Table 1 occurs at $2 \theta=26.630$ degrees, which is

26.630 degrees $\frac{3.14159}{180 \text { degree }}=0.46478$ radians.

Solving for the $d$-spacing gives

$d=\frac{1.5406 \mathrm{~A}}{2 \sin (0.46478 / 2)}=3.3447 \mathrm{~A}$.

Background intensities were estimated by graphically connecting background signals on both sides of the peak and reading the background intensity at the $2 \theta$ value of the peak. The background intensity was subtracted from the peak intensity.

\section{B.5 Test solution dilution factor and dilution-corrected solution concentration}

The test solution recovered from the test vessel was passed through a $0.45-\mathrm{m}$ pore size filter directly into a pre-weighed polyethylene solution bottle. An aliquot of the solution was removed for $\mathrm{pH}$ analysis and the remaining solution weighed. Demineralized water was added to some test solutions so that about 10 $\mathrm{mL}$ was available for analysis. About $0.05 \mathrm{~g}$ concentrated nitric acid was added to the solution and the total mass weighed. A dilution factor was calculated from the masses and used to correct the measured concentrations. In the following expressions, parentheses are used to denote measured quantities. 
dilution factor $=\frac{\left(\text { mass bottle }+ \text { test solution }+ \text { DIW }+\mathrm{HNO}_{3}\right)-(\text { mass bottle })}{(\text { mass bottle }+ \text { test solution })-(\text { mass bottle })}$

dilution-corrected concentration $=$ measured solution concentration $\times$ dilution factor

For example, in Table 3, the measured masses for Cs-Blank-1 test solution are

mass bottle $=11.09 \mathrm{~g}$

mass bottle + test solution $=23.32 \mathrm{~g}$

mass bottle + test solution $+\mathrm{DIW}+\mathrm{HNO}_{3}=23.36 \mathrm{~g}$.

The dilution factor for the Cs solution is $\frac{23.36-11.09}{23.32-11.09}=1.0033$.

Also from Table 3, the measured masses for Sr-Blank-1 test solution are

mass bottle $=11.10 \mathrm{~g}$

mass bottle + Sr test solution $=23.35 \mathrm{~g}$

mass bottle $+\mathrm{Sr}$ test solution $+\mathrm{DIW}+\mathrm{HNO}_{3}=23.40 \mathrm{~g}$.

The dilution factor for the Sr solution is $\frac{23.40-11.10}{23.35-11.10}=1.0041$.

\section{B.6 Dilution factors for mixed test solutions}

After they were acidified, test solutions from corresponding tests with Cs and Sr were combined for analysis. The solutions were combined in a new solution bottle. The masses are measured for the empty bottle, the bottle + the Cs solution, and bottle + Cs solution + Sr solution. The dilution factors for the Cs and $\mathrm{Sr}$ test solutions due to this mixing were calculated as

Cs dilution factor $=\frac{(\text { mass bottle }+ \text { Cs test solution }+ \text { Sr test solution })-(\text { mass bottle })}{(\text { mass bottle }+ \text { Cs test solution })-(\text { mass bottle })}$

Sr dilution factor $=\frac{(\text { mass bottle }+ \text { Cs test solution }+ \text { Sr test solution })-(\text { mass bottle })}{(\text { mass bottle }+ \text { Cs test solution }+ \text { Sr test solution })-(\text { mass bottle }+ \text { Cs test solution })}$

The test solutions Cs-Blank-1 and Sr-Blank-1 were mixed for analysis. From Table 4, the measured masses were

Mass bottle $=11.09 \mathrm{~g}$

Mass bottle + acidified Cs-Blank-1 test solution (solution 1$)=23.24 \mathrm{~g}$

Mass bottle + Cs solution + acidified Sr-Blank-1 test solution (solution 2) $=35.46 \mathrm{~g}$

Cs dilution factor $=\frac{35.46 \mathrm{~g}-11.09 \mathrm{~g}}{23.24 \mathrm{~g}-11.09 \mathrm{~g}}=2.0058$

Sr dilution factor $=\frac{34.46 \mathrm{~g}-11.09 \mathrm{~g}}{34.46 \mathrm{~g}-23.24 \mathrm{~g}}=1.9943$. 
The total dilution factor for the Cs solution is $1.0033 \times 2.0058=2.0124$. The dilution due to acidification contributes $0.3 \%$ to the total and was ignored in the calculations.

From Table 5, the Cs and $\mathrm{Sr}$ concentrations measured in the combined solution Cs/Sr-Blank-1 were $12500 \mu \mathrm{g} / \mathrm{L} \mathrm{Cs}$ and $5450 \mu \mathrm{g} / \mathrm{L} \mathrm{Sr}$. The dilution-corrected Cs and Sr concentrations are

$2.0124 \frac{12500 \mu \mathrm{g}}{\mathrm{L}}=25155 \mu \mathrm{g} / \mathrm{L} \mathrm{Cs} \quad$ and $\quad 1.9943 \frac{5450 \mu \mathrm{g}}{\mathrm{L}}=10869 \mu \mathrm{g} / \mathrm{L} \mathrm{Sr}$.

\section{B.7 Test solution $\mathrm{pH}$}

The $\mathrm{pH}$ values of commercial $\mathrm{pH}$ buffer standards and test solutions were measured using microcombination electrode and multivoltmeter. The meter settings were not adjusted based on the buffer readings, rather the as-measured values for the buffers and solutions were recorded and later used to calculate the correlation between the certified buffer values and the measured values, and that correlation was used to calculate the true $\mathrm{pH}$ values of the test solutions. As and example, buffers for $\mathrm{pH} 3,7$, and 10 were measured on June 30, 2011:

\begin{tabular}{|c|c|c|}
\hline Buffer & Before Measuring Test Solutions & After Measuring Test Solutions \\
\hline 3 & 2.137 & 2.184 \\
\hline 7 & 6.117 & 6.150 \\
\hline 10 & 8.776 & 8.790 \\
\hline
\end{tabular}

Linear regression of the certified values against the measured values (using all measurements weighted equally) gave the relationship

actual $\mathrm{pH}=$ measured $\mathrm{pH} \times 1.053+0.6726$.

That equation was used to calculate the $\mathrm{pH}$ values of the test solutions that were measured.

The $\mathrm{pH}$ of the test solution from SJ1-Cs-B-2 was measured to be 7.037. Inserting this value gives a pH of

$7.037 \times 1.053+0.6726=8.083$

\section{B.8 Calculation of $K_{d}$ (mass in leachant, mass in test solution, mass on soil)}

The value of $K_{\mathrm{d}}(\mathrm{Cs})$ is calculated from the mass Cs in the leachant, the mass of Cs in the test solution, and the concentration of $\mathrm{Cs}$ in the test solution. The mass of Cs in the leachant is calculated using the average Cs concentration in the leachant blank tests and the mass of leachant used in the test of interest.

In the data sheet in ASTM C1733 Table 1, these are referred to (using Cs as the contaminant) as:

Total volume of liquid: $\mathrm{V}$

Starting concentration of Cs in leachant (contact solution): Cs

Final concentration of $\mathrm{Cs}$ in test solution (contact solution): $\mathrm{Cf}$

Dry mass of solid: $\mathrm{M}$

The quantity of Cs sorbed on the solid $\left(Q_{\mathrm{s}}\right)$ is calculated as:

$Q_{s}=\left(V \times C_{s}\right)-\left(V \times C_{f}\right)$ 
The concentration of Cs sorbed on the solid (S) is calculated as:

$S=\frac{\left(V \times C_{s}\right)-\left(V \times C_{f}\right)}{M}=Q_{s} / M$

The distribution coefficient $\left(K_{\mathrm{d}}\right)$ is calculated as:

$K_{d}=\frac{\frac{\left(V \times C_{s}\right)-\left(V \times C_{f}\right)}{M}}{C_{f}}=S / C_{f}$

The Cs concentrations measured in the three blank tests with the Cs A solution are $25.07 \mathrm{mg} / \mathrm{L}, 25.25$ $\mathrm{mg} / \mathrm{L}$, and $24.096 \mathrm{mg} / \mathrm{L}$, having an average of $25.10 \mathrm{mg} / \mathrm{L}$.

The effect of scale test SJ2-Cs-A-Y-13 is used as an example. From Table 9, the mass of leachant used is $25.02 \mathrm{~g}$. From the density of the Cs solution, this corresponds to a volume of

$25.10 \mathrm{~g} \frac{\mathrm{mL}}{0.9946 \mathrm{~g}}=25.24 \mathrm{~mL}$

and provides a mass of $\mathrm{Cs}$ equal to

$25.24 \mathrm{~mL} \frac{25.1 \mathrm{mg}}{\mathrm{L}} \frac{\mathrm{L}}{1000 \mathrm{~mL}} \frac{1000 \mu \mathrm{g}}{\mathrm{mg}}=633.52 \mu \mathrm{g} \mathrm{Cs}$.

From Table 10, the dilution-corrected concentration of Cs in the SJ2-Cs-A-Y-13 test solution is 1072 $\mu \mathrm{g} / \mathrm{L}$. Assuming that the volume of test solution is the same as the volume of leachant used in the test, the mass of Cs remaining in the test solution can be calculated as

$25.24 \mathrm{~mL} \frac{1072 \mu \mathrm{g}}{\mathrm{L}} \frac{\mathrm{L}}{1000 \mathrm{~mL}}=27.06 \mu \mathrm{g} \mathrm{Cs}$.

By difference, the mass of Cs taken up by the soil is

$633.52 \mu \mathrm{g}$ Cs in leachant $-27.06 \mu \mathrm{g}$ Cs $=606.46 \mu \mathrm{g}$ Cs on soil.

From Table 9, $1.00 \mathrm{~g}$ soil was used in test SJ2-Cs-A-Y-13, so the Cs concentration on the soil is 606.46 $\mu \mathrm{g} \mathrm{Cs} / \mathrm{g}$ soil. The Cs concentration in the test solution is $1.072 \mu \mathrm{g} / \mathrm{mL}$, so $K_{\mathrm{d}}$ is

$K_{d}=\frac{606.46 \mu \mathrm{g} / \mathrm{g}}{1.072 \mu \mathrm{g} / \mathrm{mL}}=565.7 \mathrm{~mL} / \mathrm{g}$

\section{B.9 Linearization of the Langmuir equation}

The Langmuir equation given in Equation 15 is rearranged to the linearized Equation 16 by the following steps 


$$
\begin{aligned}
& C_{\text {soil }}=b \frac{K_{\mathrm{L}} C_{\text {solution }}}{\left(1+K_{L} C_{\text {solution }}\right)} \\
& C_{\text {soil }}+K_{L} C_{\text {solution }} C_{\text {soil }}=b K_{\mathrm{L}} C_{\text {solution }} \\
& \frac{C_{\text {soil }}}{b K_{\mathrm{L}}}+\frac{K_{L} C_{\text {solution }} C_{\text {soil }}}{b K_{\mathrm{L}}}=C_{\text {solution }} \\
& \frac{1}{b K_{\mathrm{L}}}+\frac{C_{\text {solution }}}{b}=\frac{C_{\text {solution }}}{C_{\text {soil }}}
\end{aligned}
$$




\section{Appendix C: Propagation of Errors}

The uncertainties in the rates calculated for individual tests within each test series were estimated from the measured test values using the propagation of errors method. For a property $P$ that is a function of measured values $x_{1}, x_{2}, x_{3}$, etc., the probable error associated with $P$ can be expressed in terms of the probable error in the means of the measured values as:

$$
Q_{p}{ }^{2}=\left(\frac{\partial P}{\partial x_{1}}\right)^{2} \cdot Q_{1}{ }^{2}+\left(\frac{\partial P}{\partial x_{2}}\right)^{2} \cdot Q_{2}{ }^{2}+\left(\frac{\partial P}{\partial x_{3}}\right)^{2} \cdot Q_{3}{ }^{2}+\ldots
$$

The estimated uncertainties for measured and calculated values are listed below. The partition function $K_{\mathrm{d}}$ is calculated using Eq. C.2:

$$
K_{d}=\frac{C_{\text {sorbed }}\left(g_{\text {species }} / g_{\text {soil }}\right)}{C_{\text {solution }}\left(g_{\text {species }} / m L_{\text {solution }}\right)} \text {. }
$$

The mass of a contaminant sorbed per gram solid is calculated as

$$
\begin{aligned}
& C_{\text {sorbed }}\left(g_{\text {species }} / g_{\text {sorbent }}\right)= \\
& \qquad \frac{C_{\text {leachant }}\left(g_{\text {species }} / m L_{\text {leachant }}\right) \bullet V_{\text {leachant }}(m L)-C_{\text {solution }}\left(g_{\text {species }} / m L_{\text {solution }}\right) \bullet V_{\text {solution }}(m L)}{M_{\text {sorbent }}\left(g_{\text {soil }}\right)} .
\end{aligned}
$$

Substituting this into Equation C.2 gives

$$
K_{d}=\frac{C_{\text {leachant }}\left(g_{\text {species }} / m L_{\text {leachant }}\right) \bullet V_{\text {leachant }}(m L)-C_{\text {solution }}\left(g_{\text {species }} / m L_{\text {solution }}\right) \bullet V_{\text {solution }}(m L)}{C_{\text {solution }}\left(g_{\text {species }} / m L_{\text {solution }}\right) \bullet M_{\text {sorbent }}\left(g_{\text {soil }}\right)},
$$

which can be rearranged as

$$
K_{d}=\frac{C_{\text {leachant }}\left(g_{\text {species }} / m L_{\text {leachant }}\right) \bullet V_{\text {leachant }}(m L)}{C_{\text {solution }}\left(g_{\text {species }} / m L_{\text {solution }}\right) \bullet M_{\text {sorbent }}\left(g_{\text {soil }}\right)}-\frac{C_{\text {solution }}\left(g_{\text {species }} / m L_{\text {solution }}\right) \bullet V_{\text {solution }}(m L)}{C_{\text {solution }}\left(g_{\text {species }} / m L_{\text {solution }}\right) \bullet M_{\text {sorbent }}\left(g_{\text {soil }}\right)},
$$

and simplified to

$$
K_{d}=\frac{C_{\text {leachant }} \bullet V_{\text {leachant }}}{C_{\text {solution }} \bullet M_{\text {soil }}}-\frac{V_{\text {solution }}}{M_{\text {soil }}} .
$$

The probable error in the value of $K_{\mathrm{d}}$ that is calculated with Eq. C.6 is given by:

$$
\begin{gathered}
Q_{K_{d}}{ }^{2}=\left(\frac{\partial K_{d}}{\partial C_{\text {leachant }}}\right)^{2} \bullet Q_{C_{\text {leachant }}}{ }^{2}+\left(\frac{\partial K_{d}}{\partial C_{\text {solution }}}\right)^{2} \cdot Q_{C_{\text {solution }}}{ }^{2}+\left(\frac{\partial K_{d}}{\partial M_{\text {soil }}}\right)^{2} \cdot Q_{M_{\text {soil }}}{ }^{2} \\
+\left(\frac{\partial K_{d}}{\partial V_{\text {leachant }}}\right)^{2} \cdot Q_{V_{\text {leachant }}}{ }^{2}+\left(\frac{\partial K_{d}}{\partial V_{\text {solution }}}\right)^{2} \bullet Q_{V_{\text {solution }}}{ }^{2} .
\end{gathered}
$$


The standard deviation is the square root of ${Q_{K_{d}}}^{2}$. The partial differential terms in Eq. C.7 are:

$$
\begin{aligned}
& \frac{\partial K_{d}}{\partial C_{\text {leachant }}}=\frac{V_{\text {leachant }}}{C_{\text {solution }} \bullet M_{\text {soil }}}, \\
& \frac{\partial K_{d}}{\partial C_{\text {solution }}}=-\frac{C_{\text {leachant }} \bullet V_{\text {leachant }}}{\left(C_{\text {solution }}\right)^{2} \bullet M_{\text {soil }}}, \\
& \frac{\partial K_{d}}{\partial M_{\text {soil }}}=-\left\{\frac{C_{\text {leachant }} \bullet V_{\text {leachant }}}{C_{\text {solution }}}-V_{\text {solution }}\right\} \frac{1}{\left[M_{\text {soil }}\right]^{2}}, \\
& \frac{\partial K_{d}}{\partial V_{\text {leachant }}}=\frac{C_{\text {leachant }}}{C_{\text {solution }} \bullet M_{\text {soil }}}, \\
& \frac{\partial K_{d}}{\partial V_{\text {solution }}}=\frac{-1}{M_{\text {soil }}},
\end{aligned}
$$

The individual uncertainty terms are discussed below.

\section{$Q C_{\text {leachant }}$}

The uncertainty in the concentration of the element of interest in the leachant solution is due to analytical uncertainty in the measured concentration, which is reported by the analyst to be within $10 \%$.

\section{$Q C_{\text {solution }}$}

The uncertainty in the concentration of the element of interest in the test solution is due to analytical uncertainty in the measured concentration, which is reported by the analyst to be within $10 \%$.

\section{$Q M_{\text {soil }}$}

The uncertainty in the mass of soil used in the test is computed by applying Eq. C. 1 to the difference in two measurements:

$$
\begin{gathered}
\mathrm{M}=\operatorname{mass}_{1}-\operatorname{mass}_{2} \\
Q_{M}{ }^{2}=\left(\frac{\partial M}{\partial M_{\text {mass } 1}}\right)^{2} \cdot Q_{1}^{2}+\left(\frac{\partial M}{\partial M_{\text {mass } 2}}\right)^{2} \cdot Q_{2}{ }^{2} .
\end{gathered}
$$

If the uncertainty in each measured mass is $0.01 \mathrm{~g}$, then $\frac{\partial M}{\partial \operatorname{mass}_{1}}=1, \frac{\partial M}{\partial \mathrm{mass}_{2}}=-1$, and

$Q_{1}=Q_{2}=0.01$. Inserting these values into Eq. C.14 gives:

$$
Q_{M}^{2}=(1)^{2} \bullet(0.01)^{2}+(-1)^{2} \bullet(0.01)^{2}=0.0002 \mathrm{~g} .
$$

The uncertainty in the difference of any two masses to the nearest $0.01 \mathrm{~g}$ is $Q_{M}=(0.0002)^{0.5}=0.014 \mathrm{~g}$.

$Q V_{\text {leachant }}$ 
The uncertainty in the volume of the leachant solution is due to analytical uncertainty in the measured mass, which is taken to be $0.014 \mathrm{~g}$, and the uncertainty in the density. The densities of the $1 \times 10^{-4}$ molal solutions were measured by weighing solution in a volumetric flask. The volume of the flask was measured by filling with demineralized water. The uncertainty in the leachant volume is due to two weight measurements to determine the density and one weight measurement to determine the mass, with an uncertainty of $0.014 \mathrm{~g}$ for each weight measurement. The uncertainty in the leachant volume is is $Q_{V}=$ $\left[3 \times(0.014)^{2}\right]^{1 / 2}=0.024 \mathrm{~mL}$.

$Q V_{\text {solution }}$

The mass of the test solution differs from the mass of the leachant solution due to evaporative loss during the test. The average mass loss in tests conducted with $12.5 \mathrm{~g}$ leachant was $0.017 \mathrm{~g}$, which is $0.13 \%$.

Tests conducted with $25 \mathrm{~g}$ leachant lost an average of $0.06 \mathrm{~g}$, which is $0.24 \%$. An uncertainty of $0.03 \mathrm{~mL}$ is assigned to the solution volumes of tests conducted with $12.5 \mathrm{~g}$ leachant and an uncertainty of $0.06 \mathrm{~mL}$ is assigned to the solution volumes of all tests with $25 \mathrm{~g}$ leachant.

Table C.1. Experimental values used to calculate $K_{\mathrm{d}}$ for replicate tests

\begin{tabular}{|c|c|c|c|c|c|}
\hline & $\begin{array}{c}\mathrm{V}_{\text {leachant, }} \\
\mathrm{mL}\end{array}$ & $\begin{array}{c}\mathrm{V}_{\text {solution, }} \\
\mathrm{mL}\end{array}$ & $\begin{array}{c}\mathrm{C}_{\text {leachant, }}, \\
\mu \mathrm{g} / \mathrm{L}\end{array}$ & $\begin{array}{c}\mathrm{C}_{\text {solution, }} \\
\mu \mathrm{g} / \mathrm{L}\end{array}$ & $\begin{array}{c}\mathrm{M}_{\text {soil, }}, \\
\mathrm{g}\end{array}$ \\
\hline SJ2-A-Y-1 & 50.31 & 50.31 & 25095 & 1200 & 2.00 \\
\hline SJ2-A-Y-2 & 50.27 & 50.27 & 25095 & 1140 & 2.00 \\
\hline SJ2-A-Y-3 & 50.27 & 50.27 & 25095 & 1170 & 2.00 \\
\hline SJ2-A-Y-4 & 50.30 & 50.30 & 25095 & 1120 & 2.00 \\
\hline SJ2-A-Y-5 & 50.27 & 50.27 & 25095 & 1120 & 2.00 \\
\hline SJ2-A-Y-6 & 24.91 & 24.91 & 8128 & 1013 & 1.00 \\
\hline SJ2-A-Y-7 & 24.91 & 24.91 & 8128 & 1095 & 1.00 \\
\hline SJ2-A-Y-8 & 24.93 & 24.93 & 8128 & 1073 & 1.00 \\
\hline SJ2-A-Y-9 & 24.91 & 24.91 & 8128 & 1093 & 1.00 \\
\hline SJ2-A-Y-10 & 24.95 & 24.95 & 8128 & 1142 & 1.00 \\
\hline
\end{tabular}


Table C.2. Differentials in Equation B.8 calculated using experimental values

\begin{tabular}{|c|c|c|c|c|c|}
\hline & $\frac{\partial K_{d}}{\partial C_{\text {leachant }}}$ & $\frac{\partial K_{d}}{\partial C_{\text {solution }}}$ & $\frac{\partial K_{d}}{\partial M_{\text {soil }}}$ & $\frac{\partial K_{d}}{\partial V_{\text {leachant }}}$ & $\frac{\partial K_{d}}{\partial V_{\text {solution }}}$ \\
\hline SJ2-A-Y-1 & 0.0210 & -0.4384 & -250.4461 & 10.4563 & -0.5 \\
\hline SJ2-A-Y-2 & 0.0220 & -0.4853 & -264.0782 & 11.0066 & -0.5 \\
\hline SJ2-A-Y-3 & 0.0215 & -0.4608 & -256.9847 & 10.7244 & -0.5 \\
\hline SJ2-A-Y-4 & 0.0225 & -0.5031 & -269.1797 & 11.2031 & -0.5 \\
\hline SJ2-A-Y-5 & 0.0224 & -0.5028 & -269.0183 & 11.2031 & -0.5 \\
\hline SJ2-A-Y-6 & 0.0246 & -0.1973 & -174.9725 & 8.0231 & -1 \\
\hline SJ2-A-Y-7 & 0.0228 & -0.1690 & -160.0628 & 7.4247 & -1 \\
\hline SJ2-A-Y-8 & 0.0232 & -0.1759 & -163.8942 & 7.5732 & -1 \\
\hline SJ2-A-Y-9 & 0.0228 & -0.1694 & -160.2990 & 7.4341 & -1 \\
\hline SJ2-A-Y-10 & 0.0218 & -0.1554 & -152.5777 & 7.1144 & -1 \\
\hline
\end{tabular}

Table C.3. Uncertainties in experimental measurements

\begin{tabular}{|c|c|c|c|c|c|}
\hline & $\boldsymbol{Q C}_{\text {leachant }}$ & $\boldsymbol{Q C _ { \text { solution } }}$ & $\boldsymbol{Q M}_{\text {soil }}$ & $\boldsymbol{Q V}_{\text {leachant }}$ & $\boldsymbol{Q V}_{\text {solution }}$ \\
\hline & $\mu \mathrm{g} / \mathrm{L}$ & $\mu \mathrm{g} / \mathrm{L}$ & $\mathrm{g}$ & $\mathrm{mL}$ & $\mathrm{mL}$ \\
\hline SJ2-A-Y-1 & 2509.5 & 120.00 & 0.014 & 0.024 & 0.03 \\
\hline SJ2-A-Y-2 & 2509.5 & 114.00 & 0.014 & 0.024 & 0.03 \\
\hline SJ2-A-Y-3 & 2509.5 & 117.00 & 0.014 & 0.024 & 0.03 \\
\hline SJ2-A-Y-4 & 2509.5 & 112.00 & 0.014 & 0.024 & 0.03 \\
\hline SJ2-A-Y-5 & 2509.5 & 112.00 & 0.014 & 0.024 & 0.03 \\
\hline SJ2-A-Y-6 & 812.8 & 101.31 & 0.014 & 0.024 & 0.03 \\
\hline SJ2-A-Y-7 & 812.8 & 109.47 & 0.014 & 0.024 & 0.03 \\
\hline SJ2-A-Y-8 & 812.8 & 107.33 & 0.014 & 0.024 & 0.03 \\
\hline SJ2-A-Y-9 & 812.8 & 109.33 & 0.014 & 0.024 & 0.03 \\
\hline SJ2-A-Y-10 & 812.8 & 114.25 & 0.014 & 0.024 & 0.03 \\
\hline
\end{tabular}

Table C.4. Calculated terms in Equation C.7

\begin{tabular}{|c|c|c|c|c|c|c|}
\hline & $\begin{array}{c}\text { C leachant } \\
\text { term }\end{array}$ & $\begin{array}{c}\text { C solution } \\
\text { term }\end{array}$ & $\begin{array}{c}\text { M soil } \\
\text { term }\end{array}$ & $\begin{array}{c}\text { V leachant } \\
\text { term }\end{array}$ & $\begin{array}{c}\text { V solution } \\
\text { term }\end{array}$ & Sum of terms \\
\hline SJ2-A-Y-1 & 2767.25 & 2767.25 & 12.294 & 0.06298 & 0.000225 & 5546.9 \\
\hline SJ2-A-Y-2 & 3061.31 & 3061.31 & 13.669 & 0.06978 & 0.000225 & 6136.4 \\
\hline SJ2-A-Y-3 & 2906.33 & 2906.33 & 12.944 & 0.06625 & 0.000225 & 5825.7 \\
\hline SJ2-A-Y-4 & 3175.42 & 3175.42 & 14.202 & 0.07229 & 0.000225 & 6365.1 \\
\hline SJ2-A-Y-5 & 3171.62 & 3171.62 & 14.185 & 0.07229 & 0.000225 & 6357.5 \\
\hline SJ2-A-Y-6 & 399.55 & 399.55 & 6.001 & 0.03708 & 0.000900 & 805.13 \\
\hline SJ2-A-Y-7 & 342.16 & 342.16 & 5.022 & 0.03175 & 0.000900 & 689.38 \\
\hline SJ2-A-Y-8 & 356.56 & 356.56 & 5.265 & 0.03304 & 0.000900 & 718.42 \\
\hline SJ2-A-Y-9 & 343.04 & 343.04 & 5.036 & 0.03183 & 0.000900 & 691.15 \\
\hline SJ2-A-Y-10 & 315.17 & 315.17 & 4.563 & 0.02915 & 0.000900 & 634.94 \\
\hline
\end{tabular}


Table C.5. Propagated uncertainties as standard deviations and ranges of $K_{\mathrm{d}}$ values for replicate tests

\begin{tabular}{|c|c|c|c|c|c|}
\hline & $\begin{array}{c}\text { Standard } \\
\text { Deviation }\end{array}$ & $\begin{array}{c}K_{\mathrm{d}}(\mathrm{Cs}), \\
\mathrm{mL} / \mathrm{g}\end{array}$ & & $\begin{array}{c}\text { Standard } \\
\text { Deviation }\end{array}$ & $\begin{array}{c}K_{\mathrm{d}}(\mathrm{Sr}), \\
\mathrm{mL} / \mathrm{g}\end{array}$ \\
\hline SJ2-A-Y-1 & 74.48 & 500.9 & SJ2-A-Y-6 & 28.37 & 175.0 \\
\hline SJ2-A-Y-2 & 78.33 & 528.1 & SJ2-A-Y-7 & 26.26 & 160.1 \\
\hline SJ2-A-Y-3 & 76.33 & 514.0 & SJ2-A-Y-8 & 26.80 & 163.9 \\
\hline SJ2-A-Y-4 & 79.78 & 538.4 & SJ2-A-Y-9 & 26.29 & 160.3 \\
\hline SJ2-A-Y-5 & 79.73 & 538.0 & SJ2-A-Y-10 & 25.20 & 152.6 \\
\hline \multicolumn{2}{r|r}{ Mean } & 523.88 & & Mean & 162.38 \\
\hline \multicolumn{2}{r}{ Standard Deviation } & 16.23 & \multicolumn{3}{r}{} \\
\hline
\end{tabular}




\section{Argonne}

Chemical Sciences and Engineering Division

Argonne National Laboratory

9700 South Cass Avenue, Bldg. 205

Argonne, IL 60439-4837

www.anl.gov 